Check for updates

Cite this: RSC Adv., 2017, 7, 55175

\title{
Emerging trends in organotellurolate chemistry derived from platinoids
}

\begin{abstract}
Rohit Singh Chauhan (D)*a and Neelam Shivran ${ }^{b}$
This perspective begins with the discussion of various basic synthetic approaches applied for the synthesis of several organotellurium ligands, their chemistry derived from platinum group metals, and the reactivity difference among them. It also gives an overview on the development of various bi, tri, and high nuclearity complexes syntheses. Investigations targeting the organotellurium ligand systems revealed a remarkable reactivity due to the dynamic nature of the lone pair available on the tellurium metal, which has led to a serendipitous isolation of the complexes $\left[\mathrm{Cp} * \operatorname{Ir}(\mathrm{ppy})\left(\eta^{1}-\mathrm{Te}_{2} \mathrm{Ph}_{2}\right)\right]^{+}, \quad\left[\mathrm{Cp}^{*} \mid \mathrm{IOs}_{3}(\mu-\mathrm{H})_{2}\right.$ $\left.(\mu \text {-Tetol) })_{2}(\mathrm{CO})_{7}\right],\left[\mathrm{Pt}\left\{\mathrm{TeC}_{5} \mathrm{H}_{3}(3-\mathrm{R}) \mathrm{N}\right\}_{2} \mathrm{Te}\left(\mathrm{PPh}_{3}\right)\right]$, $\left[\mathrm{Pt}\left\{\mathrm{Ph}_{2} \mathrm{PCH}\left(\mathrm{TeC}_{5} \mathrm{H}_{3}(3-\mathrm{R}) \mathrm{NPPh}_{2}\right)\right\}_{2}\right](\mathrm{R}=\mathrm{H}, \mathrm{Me})$, and various other high nuclearity heterometallic $\left[\mathrm{Cp} * \operatorname{lr}(\mathrm{CO})\left(\mu-\mathrm{TeC}_{6} \mathrm{H}_{4}\right)_{2} \mathrm{MCp} * \mathrm{Cl}\right] \mathrm{Cl}(\mathrm{M}=\mathrm{Rh}, \mathrm{Ir})$ complexes. Studies of the various complexes investigated the various binding modes of coordination and the facile cleavage of the $\mathrm{Te}-\mathrm{C}$ and $\mathrm{Te}-\mathrm{Te}$ bonds of tellurium-based ligand systems. Attempts have been made to present a comprehensive account of the subject matter. Various promising aspects of these complexes, such as their synthesis, reactivity, structures, and applications, are covered in this review.
\end{abstract}

Received 26th August 2017

Accepted 20th November 2017

DOI: $10.1039 / c 7 r a 09480 a$

rsc.li/rsc-advances

Renewed interest in the field of coordination chemistry

\section{Introduction}

Organosulphur and selenium derived metal complexes have been well documented for more than several decades. ${ }^{1-4}$ When one considers its homologues analog involving tellurium elements, it is clear that tellurium chemistry is still relatively uncharted. Due to their high reactivity, air sensitivity, and diffusive sets of orbitals, tellurium complexes are unstable and hence unexplored. Thus, the prompt reactivity and rich coordination of organotellurium ligand systems has drawn substantial interest over the last few years. ${ }^{5-10}$

The metalloid character of tellurium makes it amphoteric (acid as well as base) in nature depending upon the nature of the reactive substrate. ${ }^{6,11-13}$ Therefore, the reactions of organotellurium ligands with platinum group metal precursors represent an active area for further research. ${ }^{14-18}$ The noteworthy reactivity of platinoids has been utilized in synthetic chemistry to isolate products in quite good yields with great selectivity under normal conditions. ${ }^{19}$ These complexes are not only used as precursors but are also envisaged as an active species in various catalytic reactions. In particular, the superior stability of the platinum family complexes endow them with an opportunity to be utilized to comprehend the mechanistic details as well as the nature of complexes involved in particular catalytic cycles. ${ }^{20}$

\footnotetext{
${ }^{a}$ Department of Chemistry, K. J. Somaiya College of Science and Commerce, Vidyavihar, Mumbai-400 077, India.E-mail: rohit.chauhan@somaiya.edu

${ }^{b}$ Department of Chemistry, Indian Institute of Science Education and Research, Pune411008, India
} derived from organotellurium ligand systems has been stimulated by a number of recent publication $\mathrm{s}^{7,8,21-23}$ dealing with the oxidative addition reactions of platinum group metal precursors with various diarylditelluride ligand systems. The outcomes of these reactions depend upon the nature of the solvent, especially in chlorinated solvents, which yield multinuclear complexes together with several unidentified products; ${ }^{21-23}$ whereas, the similar reaction in solvents like benzene and toluene affords different multinuclear complex. The formation of several products mainly results from the bond cleavage of $\mathrm{Te}-\mathrm{C}$ bonds rather than $\mathrm{Te}-\mathrm{Te}$ bonds. $^{22,23}$ The comparable bond energies of $\mathrm{Te}-\mathrm{Te}$ and $\mathrm{Te}-\mathrm{C}$ bonds and the increased metallic character of Te may be the reason for the unexpected reactivity of organotellurium ligands.

Thus, this perspective aims to cover the various synthetic approaches for organotellurium ligands, different aspects and versatility of platinum group metal complexes derived from these ligand systems, with a particular emphasis on hemilabile tellurolate ligand systems since the subject was recently explored.

\section{Synthetic strategy of various organo-tellurium ligands}

\subsection{Telluroethers}

The synthetic approaches applied for the synthesis of various monodentate, bidentate, and hybrid telluroethers have been reviewed previously by various groups. ${ }^{6,24-28}$ However, there have been no significant recent developments reported. The 
common synthetic methods applied for the synthesis of telluroethers are highlighted in the following.

2.1.1. Reduction of ditellurides. This is one of the most effective methods used, in which the reduction of ditellurides takes place accompanied with the addition of organic halides compounds. The molar quantity of organic halides is usually double with respect to ditellurides. This method has also been used in the preparation of various asymmetrical telluroethers, but there are some issues around the poor yield due to the formation of symmetrical telluroethers. Most recently Prof. A. K. Singh et al. recently developed various telluroethers, such as (2-phenyltelluromethyl)tetrhydropyran/dioxane, ${ }^{24}$ (2-phenyltelluromethyl)tetrhydropyran, ${ }^{24} \mathrm{Te}\left(\mathrm{CH}_{2} \mathrm{CH}_{2} \mathrm{R}\right)_{2}\left(\mathrm{R}=\mathrm{CH}_{2} \mathrm{NH}_{2}\right.$, $\left.\mathrm{C}_{4} \mathrm{H}_{8} \mathrm{~N}\right),{ }^{25}\left(4-\mathrm{RC}_{6} \mathrm{H}_{4}\right) \mathrm{Te}\left(\mathrm{CH}_{2} \mathrm{CH}_{2}\right)\left\{2-\mathrm{C}_{5} \mathrm{H}_{4} \mathrm{~N}\right\}(\mathrm{R}=\mathrm{H}, \mathrm{Me}, \mathrm{OMe}),{ }^{25}$ $4-\mathrm{MeOC}_{6} \mathrm{H}_{4} \mathrm{Te}\left(\mathrm{CH}_{2}\right)_{2} \mathrm{~N}=\mathrm{C}\left(\mathrm{CH}_{3}\right)\left(2-\mathrm{HOC}_{6} \mathrm{H}_{4}\right),{ }^{26} \quad \mathrm{Te}\left(\mathrm{CH}_{2} \mathrm{CH}_{2} \mathrm{~N}=\right.$ $\left.\mathrm{C}\left(\mathrm{CH}_{3}\right) \mathrm{C}_{6} \mathrm{H}_{4}-2-\mathrm{OH}\right)_{2},{ }^{26} 2-\mathrm{CH}_{3} \mathrm{SC}_{6} \mathrm{H}_{4} \mathrm{C}=\mathrm{NCH}_{2} \mathrm{CH}_{2} \mathrm{TeC}_{6} \mathrm{H}_{4}-\mathrm{OMe},{ }^{27}$ $4-\mathrm{MeOC}_{6} \mathrm{H}_{4} \mathrm{Te}\left(\mathrm{CH}_{2}\right)_{n} \mathrm{C}=\mathrm{N}\left(2-\mathrm{HOC}_{6} \mathrm{H}_{4}\right)\left(\mathrm{C}_{6} \mathrm{H}_{5}\right),{ }^{28}$ applying the same strategy.

2.1.2. In situ generation of $\mathrm{Na}_{2}$ Te. The second most efficient strategy for the formation of telluroethers is the in situ formation of $\mathrm{Na}_{2} \mathrm{Te}$, followed by the addition of the corresponding alkyl halides to isolate the desired product. As an example, the class of cyclic ditelluroether [8] aneTe $_{2}$ was synthesized in a similar fashion by the addition of a half equivalent of 1,3 dibromomethane in a THF solution of $\mathrm{Na}_{2} \mathrm{Te}$, followed by the addition of $\mathrm{NaBH}_{4}$ and a further equivalent of 1,3 dibromomethane..$^{29,30}$ The syntheses of mixed donor thia/tellura [9] $\mathrm{aneS}_{2} \mathrm{Te}_{2},[11] \mathrm{aneS}_{2} \mathrm{Te}_{2},[12]$ aneS $_{2} \mathrm{Te}_{2}$, [14] $\mathrm{aneS}_{3} \mathrm{Te}$ macrocyclic ligands and tripodal telluroether were also carried out based on the same strategy. ${ }^{31-35}$

2.1.3. Applying a Grignard reagent. Currently, Grignard reagent is also used as a promising methodology for the formation of telluroethers, especially for the isolation of heteroaromatic analogs and for unsymmetrical telluroether synthesis. In this case, the insertion of tellurium metal in to the Grignard reagent of the organic moiety corresponding to the expected telluroether is performed first. Subsequently, the addition of halo aryl or alkyl is followed in freezing conditions. Recently, an unsymmetrical 1-naphthyl-based telluroether and symmetrical pyridyl telluroethers have been isolated with the same strategy. ${ }^{36-38}$ In order to justify the mechanistic details, we performed the following process: (i) halopyridine underwent a complete metal-halogen exchange reaction with $i$-prMgCl to give pyridyl magnesium chloride, (ii) the latter compound was reacted with an equivalent of tellurium metal via an insertion mode, (iii) followed by the addition of alkyl/ aryl halide to yield the desired telluroether with the elimination of $\mathrm{MgCl}_{2}$.

\subsection{Diorganotellurides}

The majority of synthetic approaches have been applied to the synthesis of various ditelluride ligand systems. Among these, the insertion of elemental tellurium in to reactive $\mathrm{M}-\mathrm{C}$ bonds is a quite common methodology. Various approaches are described below.
2.2.1. Insertion of chalcogen in to Li-Aryl bond. The insertion of elemental tellurium in to the Li-aryl bond followed by oxidation has been performed for the synthesis of various ditelluride ligand systems. The lithiation of bromoaryl compounds has been accomplished by the substitution of the bromo group through lithium metal with reagents like $n$-BuLi ${ }^{39,40}$ or $\mathrm{Bu}^{t} \mathrm{Li}^{41}$ in polar solvents like THF and petroleum ether at a temperature of $-78{ }^{\circ} \mathrm{C}$. The resulting lithiated aryl group reacts with active elemental tellurium metal to yield a lithiated chalcogenolate ion, which on hydrolysis gives the corresponding diaryl ditelluride ligand systems.

2.2.2. Reaction of $\mathbf{E}^{2-}$ with haloaryl compounds. The reaction of heteroaromatic and aromatic halocompounds with ditellurido dianions in different solvents is another important synthetic pathway to synthesize a class of various ditelluride ligand systems. In most of the reactions, reducing reagents are generated through an in situ mode by a variety of reducing agents, like $\mathrm{NaBH}_{4}$, Li metal reaction, $\mathrm{Na} / \mathrm{NH}_{3}$, and hydrazine. ${ }^{42-47}$ Sodium borohydride reduction of elemental tellurium in ethanol, water, and ethoxy ethanol has been applied for the synthesis for $\mathrm{Na}_{2} \mathrm{Te}_{2} \cdot{ }^{45-48}$ The latter has been synthesized by an in situ and dropwise addition of haloaryl compounds, yielding the corresponding diaryl ditelluride; while hydrazine hydrate in the presence of $\mathrm{NaOH}$ in DMF has also been used to prepare $\mathrm{Na}_{2} \mathrm{Te}_{2}$, which on reaction with bromopyridine and chloropyrimidines, affords their corresponding ditellurides (Scheme 1). ${ }^{49}$

2.2.3. Insertion of tellurium in to aryl magnesium halide. The lithiation of haloaryl compounds takes place at $-78^{\circ} \mathrm{C}$, but this cryogenic condition and the instability of the lithiated products results in a poor yield, which makes this method really an inconvenient route for the synthesis of ditellurides. In contrast, the stability and ease of handling of aryl magnesium bromide compounds makes this synthetic strategy quite trendy. Normally for all cases, a Grignard reagent of the corresponding alkyl or arylhalo compounds is first synthesized, ${ }^{36,37,50,51}$ followed by the insertion of elemental tellurium, which on acid hydrolysis yields the corresponding ditellurides in a moderate yield.

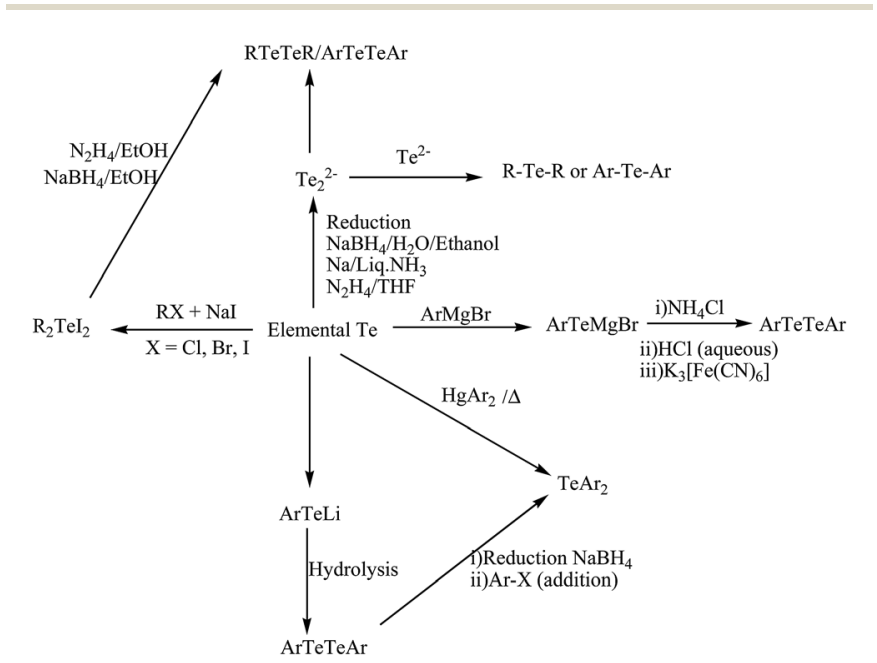

Scheme 1 Synthetic approaches for the synthesis of various ditellurides and monotellurides. 


\section{Metal complexes with telluroether ligands}

\subsection{Ruthenium and osmium}

The reaction of $\mathrm{RuCl}_{3} \cdot n \mathrm{H}_{2} \mathrm{O}, \mathrm{TePh}_{2}$, and $\mathrm{CO}$ yields the complex $\left[\mathrm{Ru}(\mathrm{CO})_{2} \mathrm{Cl}_{2}(\mathrm{TePh})_{2}\right]$, which has also been obtained in moderate yield by the simple addition between $\left[\mathrm{Ru}\left\{(\mathrm{CO})_{3} \mathrm{Cl}_{2}\right\}_{2}\right]$ and telluroether. ${ }^{52,53}$ The reaction of chelated ditelluroether $\mathrm{RTe}\left(\mathrm{CH}_{2}\right)_{3} \mathrm{TeR} ;\left(\mathrm{R}=\mathrm{Me}, \mathrm{Ph}\right.$, or $\left.o-\mathrm{C}_{6} \mathrm{H}_{4}(\mathrm{TeMe})_{2}\right)$ with $\mathrm{RuCl}_{3}$ $\cdot n \mathrm{H}_{2} \mathrm{O}, \quad\left[\mathrm{Ru}(\mathrm{dmso})_{4} \mathrm{X}_{2}\right]$ gave a complex with the general composition trans- $\left[\mathrm{RuX}_{2}(\mathrm{~L} \cap \mathrm{L})_{2}\right](\mathrm{X}=\mathrm{Cl}, \mathrm{Br}$ or $\mathrm{I}) ; \mathrm{L} \cap \mathrm{L}=$ $\mathrm{RTe}\left(\mathrm{CH}_{2}\right)_{3} \mathrm{TeR} ;\left(\mathrm{R}=\mathrm{Me}, \mathrm{Ph}\right.$ or $\left.\boldsymbol{o}-\mathrm{C}_{6} \mathrm{H}_{4}(\mathrm{TeMe})_{2}\right)$ (Scheme 2). ${ }^{54,55}$ All these products showed poor solubility in organic solvents. To overcome the solubility issues, a bulky phosphine-based ruthenium precursor, $\left[\mathrm{RuCl}_{2}\left(\mathrm{PPh}_{3}\right)_{3}\right]$, has been used, which on reaction with the same ditelluroether yielded a complex of $\left[\mathrm{RuCl}\left(\mathrm{PPh}_{3}\right)(\mathrm{L} \cap \mathrm{L})_{2}\right] \mathrm{PF}_{6}$ (Fig. 1) with good solubility in various organic solvents. ${ }^{55}$ In solution, the latter complex is converted to a product with the composition $\left[\mathrm{RuCl}_{2}\left(\mathrm{PPh}_{3}\right)\left\{\mathrm{MeC}\left(\mathrm{RTeCH}_{2}\right)\right\}_{3}\right]$, while a longer stay in the solvent results in its decomposition to unknown species; ${ }^{56}$ while this tripodal ligand on reaction with $\left[\mathrm{Ru}(\mathrm{dmf})_{6}\right]\left(\mathrm{SO}_{3} \mathrm{CF}_{3}\right)_{3}$ in methanol gave a homoleptic compound $\left[\mathrm{Ru}\left\{\mathrm{MeC}\left(\mathrm{CH}_{2} \mathrm{TeR}\right)_{3}\right\}_{2}\right]\left(\mathrm{SO}_{3} \mathrm{CF}_{3}\right)_{2}(\mathbf{I}) .^{57,58}$

A new class of carbon-backboned ligands (4- $\mathrm{MeO}-\mathrm{C}_{6} \mathrm{H}_{4}-$ $\mathrm{Te})_{2} \mathrm{CH}_{2}$ and $\left[\left(\mathrm{CH}_{2}\right)_{2} \mathrm{C}\left(\mathrm{CH}_{2} \mathrm{TeMe}\right)_{2}\right]$ on reaction with $\left[\mathrm{RuCl}_{4}\right.$ $\left.(\mathrm{dmso})_{4}\right] /\left[\mathrm{RuCl}_{2}(p \text {-cymene })\right]_{2}$ afforded the complex $\left[\mathrm{RuCl}_{2}\right.$ $\left.(\text { dmso })_{2}(\mathrm{~L})\right] /\left[\mathrm{RuCl}_{2}(p \text {-cymene })_{2}(\mathrm{~L})\right] \quad\left(\mathrm{L}=\left(4-\mathrm{MeO}-\mathrm{C}_{6} \mathrm{H}_{4}-\mathrm{Te}\right)_{2} \mathrm{CH}_{2}\right.$ and $\left.\left[\left(\mathrm{CH}_{2}\right)_{2} \mathrm{C}\left(\mathrm{CH}_{2} \mathrm{TeMe}\right)_{2}\right]\right)$ which contains a telluroether in a chelating fashion with the formation of a strained fourmembered ring. These complexes were configured in a distorted octahedral geometry around the Ru metal center. ${ }^{59}$

The reaction of $\left[\mathrm{RuCl}_{2}(p \text {-cymene })\right]_{2}$ with two equivalent of homoleptic telluroether $\mathrm{Te}\left\{\mathrm{CH}_{2} \mathrm{CH}_{2}(\mathrm{Ar})\right\}_{2}(\mathrm{Ar}=1,3$ dioxane, thiophene $)^{60}$ or a heteroleptic telluroether like [(thiophene)Te $\left.\left\{\mathrm{CH}_{2}(\mathrm{R})\right\}\right](\mathrm{R}=$ furan, pyrol $),{ }^{61}\left[\left\{\mathrm{CH}_{2} \mathrm{CH}_{2}(\mathrm{R})\right\} \mathrm{Te}\left(\mathrm{C}_{6} \mathrm{H}_{4}-p-\mathrm{OMe}\right)\right]$ $(\mathrm{R}=\text { thiophene, phthalamide, benzotriazole })^{\mathbf{6 2 , 6 3}}$ yielded $\left[\mathrm{RuCl}_{2}(p\right.$-cymene $\left.) \mathrm{L}\right]\left(\mathrm{L}=\mathrm{Te}\left\{\mathrm{CH}_{2} \mathrm{CH}_{2}(\mathrm{Ar})\right\}_{2}, \quad\left[\left\{\mathrm{CH}_{2} \mathrm{CH}_{2}(\mathrm{R})\right\}\right.\right.$ $\mathrm{Te}\left(\mathrm{C}_{6} \mathrm{H}_{4}-p\right.$-OMe $\left.)\right],\left[(\right.$ thiophene $\left.\left.) \mathrm{Te}\left\{\mathrm{CH}_{2}(\mathrm{R})\right\}\right]\right)$ (Scheme 2). The same type of composition (II) has also been derived with various tridentate hybrid ligand systems. ${ }^{64-67}$

The chemistry of halo osmium precursors $\mathrm{OsO}_{4}-\mathrm{HX}$ or $\left[\mathrm{OsX}_{6}\right]$ with telluroether has not had a successful outcome yet for dithio or diselenoether ligands. In this case, the reaction of $\left[\mathrm{OsCl}_{2}\left(\mathrm{dmso}_{4}\right]\right.$ with carbon-backboned ditelluroether $\mathrm{RTe}\left(\mathrm{CH}_{2}\right)_{3} \mathrm{TeR}, \quad \mathrm{CH}_{2}(\mathrm{TeMe})_{2}, \quad O-\mathrm{C}_{6} \mathrm{H}_{4}\left(\mathrm{CH}_{2} \mathrm{TeMe}\right)_{2}$ led to

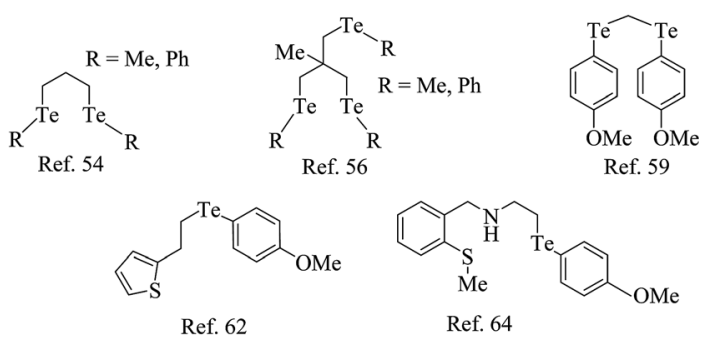

Scheme 2 Homoleptic and heteroleptic telluroether ligands.

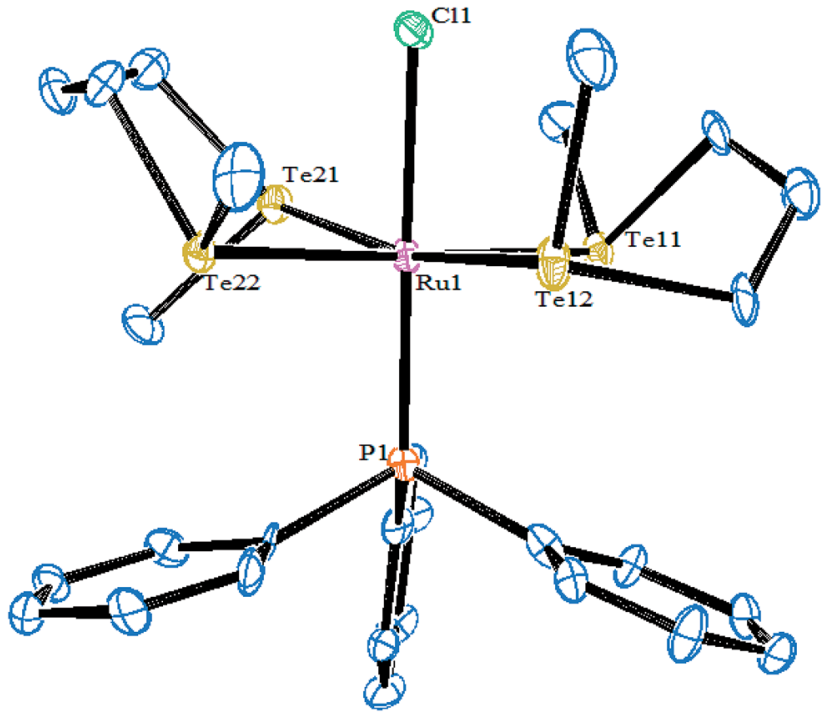

Fig. 1 Crystal structure of $\left[\mathrm{RuCl}\left(\mathrm{PPh}_{3}\right)\left\{\mathrm{MeTeCH}_{2}\right\}_{2}\right]^{+}$(redrawn from ref. 55).

a compound with the composition $\left[\mathrm{OsCl}_{2}(\mathrm{~L} \cap \mathrm{L})_{2}\right](\mathrm{III})(\mathrm{L} \cap \mathrm{L}=$ $\left.\mathrm{RTe}\left(\mathrm{CH}_{2}\right)_{3} \mathrm{TeR}, \mathrm{CH}_{2}(\mathrm{TeMe})_{2}, o-\mathrm{C}_{6} \mathrm{H}_{4}\left(\mathrm{CH}_{2} \mathrm{TeMe}\right)_{2}\right) \cdot{ }^{54,68}$ Unlike for thio and selenoether ligands, a very clean route to the final product has been achieved in the case of telluroethers. Compared to the ruthenium analogs, very few examples of telluroether-based osmium complexes are known so far.

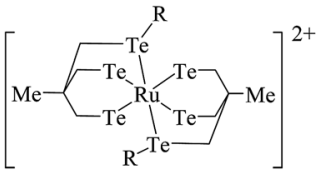

I

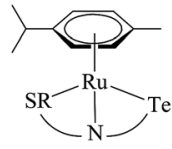

II

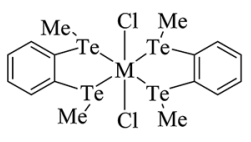

III

\subsection{Rhodium and iridium}

Very little work on rhodium and iridium complexes derived from organotellurium ligand systems, i.e., telluroethers, has been documented so far. Compared to ruthenium, the related references for rhodium and iridium complexes are less significant in number. The reaction of $\operatorname{TeR}_{2}(\mathrm{R}=\mathrm{Me}, \mathrm{Et})$ with metallocyclic $\left[\left(\mathrm{C}_{5} \mathrm{H}_{5}\right)_{2} \mathrm{Rh}_{2}(\mu-\mathrm{CO})\left(\mathrm{CF}_{3} \mathrm{CCF}_{3}\right)\right]$ derived an adduct in which $\mathrm{TeR}_{2}$ was added to one of the rhodiums attached with bridging carbonyl, which was boned in a $\eta^{1}$ fashion. ${ }^{69}$ Such a type of insertion followed by the addition of tellurium can be particularized due to diffusive sets of lone pairs and their ease of availability to coordination. While the reaction of $\mathrm{RhCl}_{3}$ $\cdot 3 \mathrm{H}_{2} \mathrm{O}$ and ditelluroethers $\mathrm{Te}\left(\mathrm{CH}_{2}\right)_{3} \mathrm{TeR}(\mathrm{R}=\mathrm{Me}, \mathrm{Ph})$ along with $\mathrm{NH}_{4} \mathrm{PF}_{6}$ in ethanol solution yielded the complex $\left[\mathrm{RhCl}_{2}(\mathrm{~L} \cap \mathrm{L})_{2}\right]$ $\mathrm{PF}_{6}$ (Scheme 3). Similarly, various tripodal $\mathrm{Rh}(\mathrm{I})$ and $\operatorname{Ir}(\mathrm{I})$ complexes $\left[\mathrm{M}\left\{\mathrm{MeC}\left(\mathrm{CH}_{2} \mathrm{TeMe}\right)_{3}\right\}(\mathrm{COD})\right] \mathrm{PF}_{6}(\mathrm{M}=\mathrm{Rh}$, Ir) were derived from umbrella-like telluroethers, namely with $\mathrm{MeC}\left(\mathrm{CH}_{2} \mathrm{TeR}\right)_{3}(\mathrm{R}=\mathrm{Me}, \mathrm{Ph}) .{ }^{55}$ However, $\mathrm{Rh}(\mathrm{III})$ complexes with the composition $\left[\mathrm{Rh}\left(\eta^{5}-\mathrm{C}_{5} \mathrm{H}_{5}\right)\left\{\mathrm{MeC}\left(\mathrm{CH}_{2} \mathrm{ER}\right)_{3}\right\}\right]\left[\mathrm{PF}_{6}\right]_{2}$ with a square pyramidal geometry were isolated by the reaction of $\left[\left\{\mathrm{RhCl}_{2}\left(\eta^{5}-\mathrm{C}_{5} \mathrm{H}_{5}\right)\right\}_{2}\right]$ and the corresponding ligand systems. ${ }^{56}$ 
$[\mathrm{M}(\mathrm{COD}) \mathrm{Cl}]_{2}+2 \mathrm{MeC}\left(\mathrm{CH}_{2} \mathrm{TeR}\right)_{3}+2 \mathrm{NH}_{4} \mathrm{PF}_{6}$

$\left[\left\{\mathrm{Rh}\left(\mathrm{C}_{5} \mathrm{H}_{5}\right) \mathrm{Cl}_{2}\right\}_{2}\right]+\mathrm{Te}\left(\mathrm{CH}_{2} \mathrm{CH}_{2} \mathrm{CH}_{2} \mathrm{TeR}\right)_{2}$
$\left[\mathrm{M}(\mathrm{COD})\left(\mathrm{MeC}\left\{\mathrm{CH}_{2} \mathrm{TeR}\right\}\right] \mathrm{PF}_{6}\right.$

$\left[\mathrm{Rh}\left(\mathrm{C}_{5} \mathrm{H}_{5}\right)\left\{\mathrm{Te}\left(\mathrm{CH}_{2} \mathrm{CH}_{2} \mathrm{CH}_{2} \mathrm{TeR}\right)_{2}\right\}\right]$

$(\mathrm{M}=\mathrm{Rh}, \mathrm{Ir} ; \mathrm{R}=\mathrm{Me}, \mathrm{Ph})$

Scheme 3 Reaction of rhodium and iridium precursors with tripodal telluroether.

The fluxional behavior of the latter complex was established by its ${ }^{1} \mathrm{H}$ NMR spectrum, which showed a single resonance for TeMe, $\mathrm{CH}_{2}$, and COD (Scheme 3). It was concluded, during a dynamic process, that a flip on and off movement takes place through the arm of the tripod around the metal center.

Similarly, when the reaction with $\mathrm{RhCl}_{3} \cdot 3 \mathrm{H}_{2} \mathrm{O}$ is employed in various mole ratios with the ligand system $\mathrm{Te}\left(\mathrm{CH}_{2} \mathrm{SiMe}_{3}\right)$, a variety of products has been isolated (Scheme 4) depending upon the mole ratio of the ligand (Fig. 2). ${ }^{70}$ Most of these complexes have shown issues with their solubility in common organic solvents. The solubility issues have been overcome with the development of a new class of telluroether in which the backbone consists of a morpholine group. Rh(III) complexes derived from the same ligand $N$-\{2aryltelluroethyl $\}$ morpholine (Scheme 4$)^{71}$ have shown ready solubility in all organic solvents other than diethyl ether and hexane, in which the complexes are sparingly soluble. Their high solubility makes them promising catalysts in the hydrogenation reactions of ketones.

\subsection{Palladium and platinum}

Compared to other platinoids, a significant amount of work has been documented on $\mathrm{Pd}(\mathrm{II})$ and $\mathrm{Pt}(\mathrm{II})$ complexes derived from telluroethers. The reaction of $\mathrm{M}_{2} \mathrm{M}^{\prime} \mathrm{Cl}_{4}\left(\mathrm{M}=\mathrm{Na}, \mathrm{K} ; \mathrm{M}^{\prime}=\mathrm{Pd}, \mathrm{Pt}\right)$ in a $1: 2$ mole ratio with homoleptic telluroether $\operatorname{Te}\left\{\mathrm{CH}_{2} \mathrm{CH}_{2}\right.$ $(\mathrm{Ar})\}_{2}$ IV $(\mathrm{Ar}=1,3 \text { dioxane, thiophene })^{\mathbf{6 0 , 6 2}}$ or a heteroleptic telluroether, like [(thiophene) $\left.\mathrm{Te}\left\{\mathrm{CH}_{2}(\mathrm{R})\right\}\right]$ ( $\mathrm{R}=$ furan, pyrol), ${ }^{6 \mathbf{1}}$ $\left[\left\{\mathrm{CH}_{2} \mathrm{CH}_{2}(\mathrm{R})\right\} \mathrm{Te}\left(\mathrm{C}_{6} \mathrm{H}_{4}\right.\right.$-p-OMe $\left.)\right](\mathrm{R}=$ thiophene, phthalamide, benzotriazole), ${ }^{62,63}$ led to a complex of the type $\left[\mathrm{MCl}_{2} \mathrm{~L}_{2}\right] \mathrm{L}=\mathrm{Te}$ $\left\{\mathrm{CH}_{2} \mathrm{CH}_{2}(\mathrm{Ar})\right\}_{2},\left[\left\{\mathrm{CH}_{2} \mathrm{CH}_{2}(\mathrm{R})\right\} \mathrm{Te}\left(\mathrm{C}_{6} \mathrm{H}_{4}-p\right.\right.$-OMe $\left.)\right]$, [(thiophene)Te $\left.\left\{\mathrm{CH}_{2}(\mathrm{R})\right\}\right] ;^{63}$ while the reaction in $1: 1$ mole ratio with $\left[\left\{\mathrm{CH}_{2} \mathrm{CH}_{2}(\mathrm{R})\right\} \mathrm{Te}\left(\mathrm{C}_{6} \mathrm{H}_{5}-p\right.\right.$-OMe $\left.)\right] \quad\left(\mathrm{R}=2-\mathrm{CH}_{3} \mathrm{SC}_{6} \mathrm{H}_{4} \mathrm{CH}=\mathrm{N}\right.$, 2- $\left.\mathrm{CH}_{3} \mathrm{SC}_{6} \mathrm{H}_{4} \mathrm{CHNH} \mathrm{V},\left\{\mathrm{C}_{6} \mathrm{H}_{5}\right\}\left\{2-\mathrm{HOC}_{6} \mathrm{H}_{4}\right\} \mathrm{C}=\mathrm{N}\right)$ VI and a variety of tridentate ligand yielded an expected additive product with the composition $[\mathrm{MCl}(\mathrm{L})]^{+} \cdot{ }^{65-69}$ Among these cyclic complexes, $\left[\mathrm{MX}_{2}\left\{\mathrm{Te}\left(\mathrm{CH}_{2}\right)_{4}\right\}_{2}\right](\mathrm{M}=\mathrm{Pd}, \mathrm{Pt} ; \mathrm{X}=\mathrm{Cl}, \mathrm{Br}, \mathrm{I})$ has been isolated from the reaction with cyclic telluroethers, i.e., telluracyclopentane $\mathrm{Te}\left(\mathrm{CH}_{2}\right)_{4} \cdot{ }^{72}$ In the case of the platinum metal system, both cis- and trans-configured complexes have been reported. However, only a trans isomer has been isolated in the case of palladium, which was also supported by its X-ray structure results (Fig. 3). ${ }^{72}$ The trans configuration was also obtained by ligand systems like 4 oxatellurane, ${ }^{73} 1,3$ dihydrobenzotellurophene, and 2,7-dihydro- $1 H$-dibenzotellurophene ligands. ${ }^{74}$ A comparative study of bidentate ligand $\mathrm{RECH}_{2} \mathrm{ER}(\mathrm{R}=\mathrm{Me}, \mathrm{Ph} \text { and } \mathrm{E}=\mathrm{S}, \mathrm{Se}, \mathrm{Te})^{75}$ with both metals showed that the thio analogs led to a very stable compound,

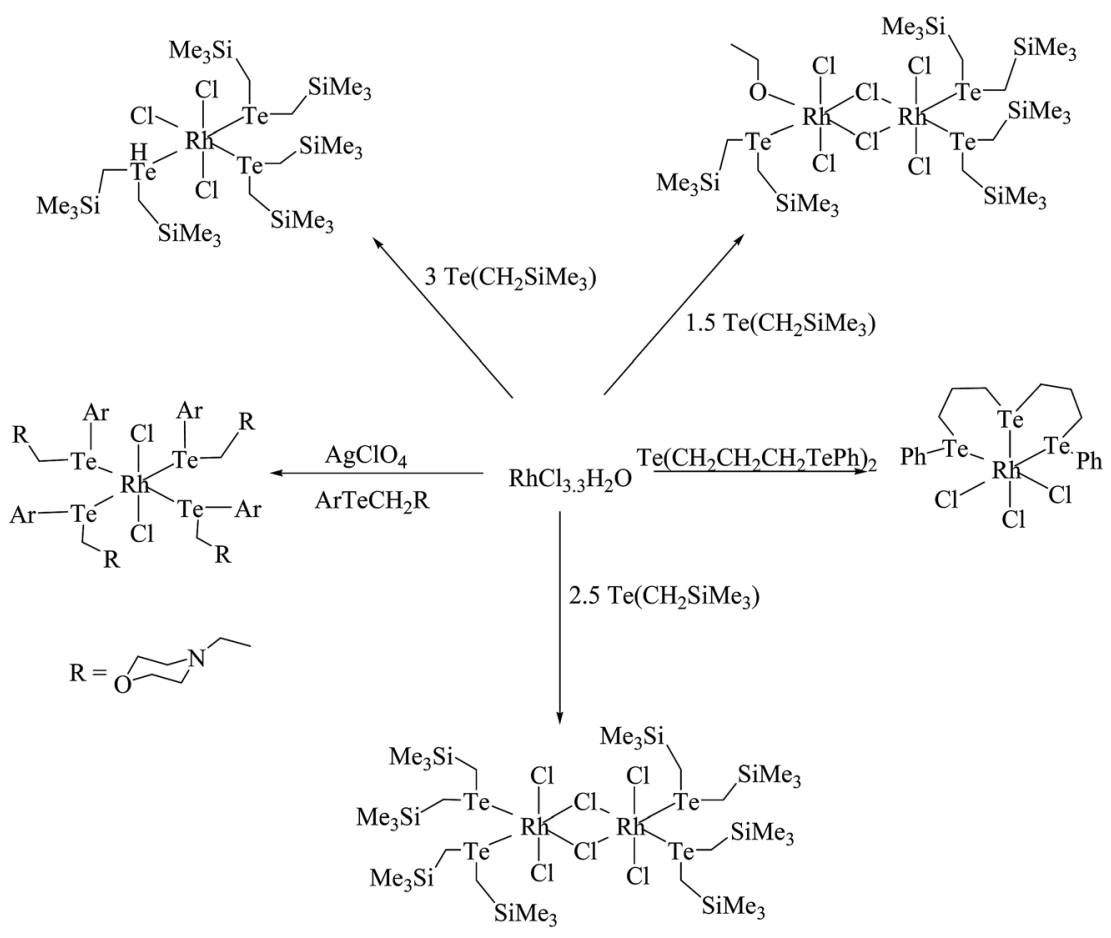

Scheme 4 Schematic representation of the reaction of $\mathrm{RhCl}_{3} \cdot 3 \mathrm{H}_{2} \mathrm{O}$ with various telluroethers. 


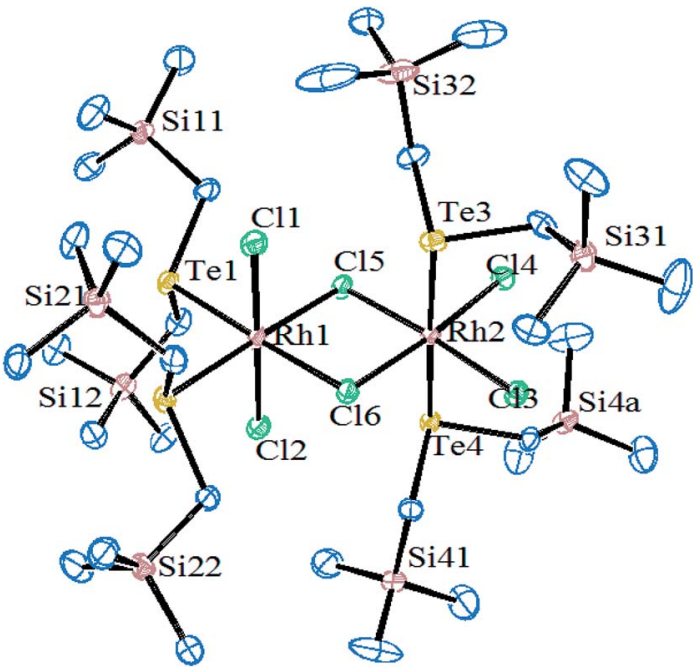

Fig. 2 Crystal structure of $\left[\mathrm{Rh}_{2} \mathrm{Cl}_{4}(\mu-\mathrm{Cl})_{2}\left\{\mathrm{Te}\left(\mathrm{CH}_{2} \mathrm{SiMe}_{3}\right)_{2}\right\}_{4}\right]$ (redrawn from ref. 70).

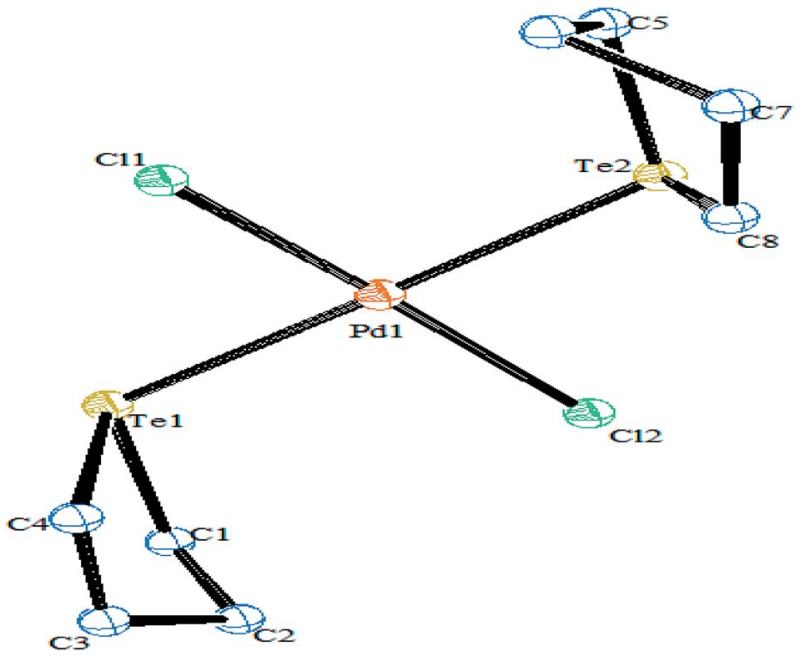

Fig. 3 Crystal structure of $\left[\mathrm{PdCl}\left\{\mathrm{Te}\left(\mathrm{CH}_{2}\right)_{4}\right\}_{2}\right]$ (redrawn from ref. 72).

namely $\left[\mathrm{MCl}_{2}\left(\eta^{1}-\mathrm{PhSCH} \mathrm{H}_{2} \mathrm{SPh}\right)_{2}\right]$, while selenium complexes are slowly decomposed into their polymeric form with the composition $\left[\left\{\mathrm{MCl}_{2}\left(\mathrm{RECH}_{2} \mathrm{ER}\right)_{2}\right\} \mathrm{n}\right]$ and a free ligand; while tellurium analogs of the same ligand, i.e., $\mathrm{RTeCH}_{2} \mathrm{TeR}(\mathrm{R}=\mathrm{Me}, \mathrm{Ph})$, only gave the polymeric $\left[\left\{\mathrm{MCl}_{2}\left(\mathrm{RECH}_{2} \mathrm{ER}\right)_{2}\right\} n\right](\mathrm{M}=\mathrm{Pd}, \mathrm{Pt})$ compounds. The similar ligand system $\left(4-\mathrm{MeOC}_{6} \mathrm{H}_{4} \mathrm{Te}\right)_{2} \mathrm{CH}_{2}$ formed a monomeric structure $\left[\mathrm{MCl}_{2}(\mathrm{~L} \cap \mathrm{L})\right]$ compound comprised of a four-membered strained ring with an acute angle of $81^{\circ}$ between Te-Pd-Te (Fig. 4). ${ }^{76,77}$
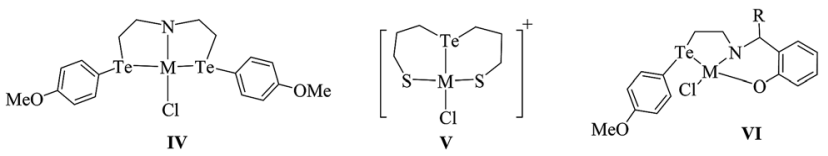

Platinum(Iv) complexes with the composition $\left[\left\{\mathrm{PtMe}_{3} \mathrm{I}_{2}\{(4-\right.\right.$ $\left.\left.\mathrm{RTe})_{2} \mathrm{CH}_{2}\right\}\right], \quad\left(\mathrm{R}=\mathrm{Ph}, \quad 4-\mathrm{MeOC}_{6} \mathrm{H}_{4}\right)$ and $\left[\left\{\mathrm{PtMe}_{3} \mathrm{I}\right\}_{2}\right.$ $\left.\left(\mathrm{PhTeCH}_{2} \mathrm{TePh}\right)_{2}\right]$, containing bridging, chelating, and

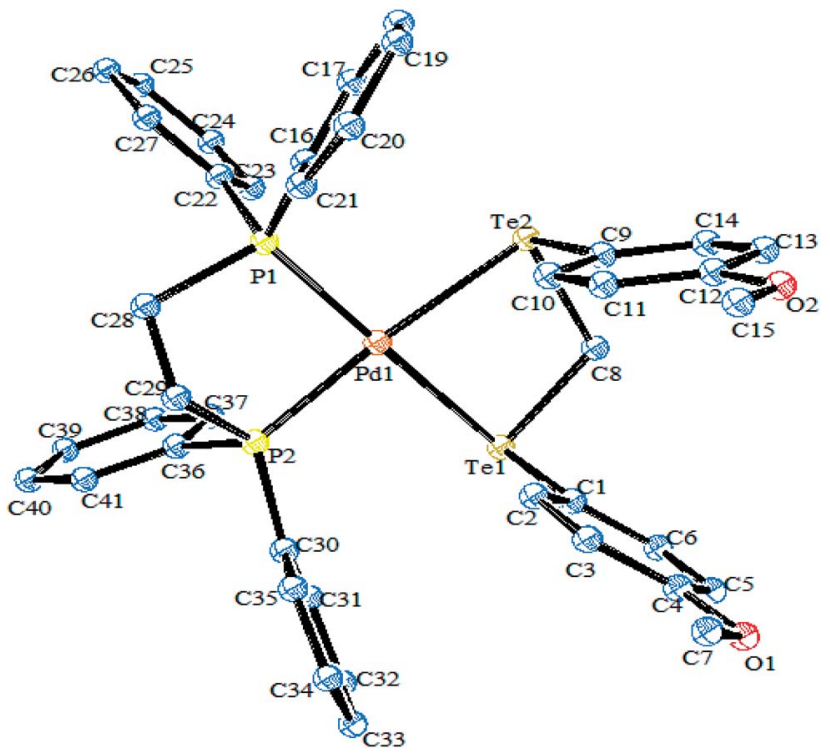

Fig. 4 Crystal structure of $\left[\mathrm{Pd}\left\{\left(4 \mathrm{MeO}-\mathrm{C}_{6} \mathrm{H}_{4} \mathrm{Te}_{2}\right) \mathrm{CH}_{2}\right\}\right.$ (dppe)] (redrawn from ref. 77).

monodentate ditelluroethers, respectively, have also been isolated. ${ }^{78}$ The homoleptic complexes $\left[\mathrm{M}(\mathrm{L} \cap \mathrm{L})_{2}\right]\left(\mathrm{PF}_{6}\right)_{2}(\mathrm{M}=\mathrm{Pd}$, Pt); $\mathrm{L} \cap \mathrm{L}=\mathrm{RTe}\left(\mathrm{CH}_{2}\right)_{3} \mathrm{TeR}, \mathrm{R}=\mathrm{Me}, \mathrm{Ph} ; o-\mathrm{CH}_{2}(\mathrm{TeMe})_{2}, o-\mathrm{C}_{6}-$ $\mathrm{H}_{4}\left(\mathrm{CH}_{2} \mathrm{TeMe}\right)_{2}, \mathrm{MeC}\left(\mathrm{CH}_{2} \mathrm{TeMe}\right)_{3}$, and $\mathrm{MeC}\left(\mathrm{CH}_{2} \mathrm{TePh}\right)_{3}$ have been prepared from $\left[\mathrm{MCl}_{2}\left(\mathrm{MeCN}_{2}\right], \mathrm{TlPF}_{6}\right.$, and the corresponding ligands in acetonitrile solution. ${ }^{54,55}$ The ${ }^{1}\{\mathrm{H}\} \mathrm{NMR}$ spectra of the above-mentioned complexes show broad resonance due to an inversion process. Prof. A. K. Singh et al. developed a series of telluroethers, namely 1,3-(4- $\mathrm{MeOC}_{6} \mathrm{H}_{4}-$ $\left.\mathrm{TeCH}_{2}\right)_{2} \mathrm{CHOH},{ }^{79} 4-\mathrm{MeOC}_{6} \mathrm{H}_{4} \mathrm{TeCH}_{2} \mathrm{CH}(\mathrm{OH}) \mathrm{CH}_{2} \mathrm{OH}, 4-\mathrm{MeOC}_{6}-$ $\mathrm{H}_{4} \mathrm{Te}\left(\mathrm{CH}_{2}\right)_{n} \mathrm{C}=\mathrm{N}\left(2-\mathrm{HOC}_{6} \mathrm{H}_{4}\right)\left(\mathrm{C}_{6} \mathrm{H}_{5}\right){ }^{80} \quad$ (2-phenyltelluromethyl) tetrhydropyran, ${ }^{81} \quad$ (2-phenyltelluromethyl)tetrhydropyran, ${ }^{82}$ $\mathrm{Te}\left(\mathrm{CH}_{2} \mathrm{CH}_{2} \mathrm{R}\right)_{2}\left(\mathrm{R}=\mathrm{CH}_{2} \mathrm{NH}_{2}, \mathrm{C}_{5} \mathrm{H}_{4} \mathrm{~N}\right),\left(4-\mathrm{RC}_{6} \mathrm{H}_{4}\right) \mathrm{Te}\left(\mathrm{CH}_{2} \mathrm{CH}_{2}\{2-\right.$ $\left.\left.\mathrm{C}_{5} \mathrm{H}_{4} \mathrm{~N}\right\}\right)(\mathrm{R}=\mathrm{H}, \mathrm{Me}, \mathrm{OMe}){ }^{83-88} \mathrm{~N}-\left\{2-\left(4-\mathrm{MeOC}_{6} \mathrm{H}_{4} \mathrm{Te}\right) \mathrm{CH}_{2} \mathrm{CH}_{2}\right\}-$ phthalimide ${ }^{89}$ with a possible one or more donor atoms, like oxygen and nitrogen, other than just the available tellurium atom (Scheme 5). Obviously, both metals (Pd, Pt) are directly bonded to tellurium with weak interactions through the donor atoms.

Tellurium has also been ligated into a macrocyclic Schiff base, and the resulting ligand VII upon reaction with $\left[\mathrm{PdCl}_{2}\right.$ $\left.(\mathrm{PhCN})_{2}\right]$ yielded the complex $\left[\left\{\mathrm{PdCl}_{2}\right\}_{2} \mathrm{~L}\right]$. In this complex,
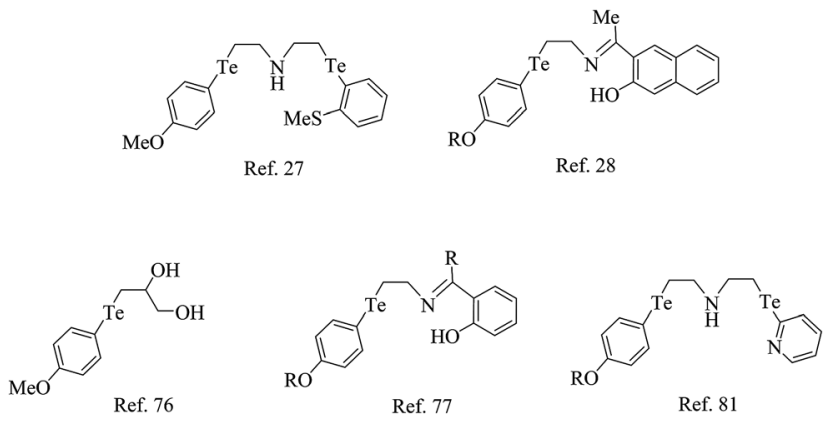

Scheme 5 Tridentate hybrid telluroether ligands. 
palladium is coordinated with each tellurium as well as the nitrogen of the Schiff base. However, the same reaction in a $1: 1$ ratio of palladium precursor to the ligand gave the product $[\mathrm{PdL}]^{+}$VIII, ${ }^{90}$ in which palladium is coordinated to the $\mathrm{Te}_{2} \mathrm{~N}_{2}$ core of the ligand, leaving the two nitrogen atoms uncoordinated (Scheme 6);1 while in the case of $\left[\mathrm{PtCl}_{2}(\mathrm{COD})\right]$, a symmetrical ring opening of the ligand took place to give the product IX, where platinum is coordinated to the $\mathrm{TeN}_{2} \mathrm{C}$ core. Surprisingly, the complexation mode of the tellurium ligand system was totally different from the similar selenium analogs. In the case of the latter ligand system, palladium is directly coordinated to all four nitrogen atoms. ${ }^{\mathbf{9 2 , 9 3}}$

An interesting example of a halobridged complex, $\left[\mathrm{M}_{2} \mathrm{X}_{2}(\mu-\right.$ $\left.\mathrm{X}_{2}\left(\mathrm{TeR}_{2}\right)_{2}\right](\mathrm{M}=\mathrm{Pd}$, Pt; $\mathrm{X}=\mathrm{Cl}, \mathrm{Br} ; \mathrm{R}=\mathrm{Mes}$, Ph, o-tol), was obtained by the treatment of $\left[\mathrm{MX}_{2}\left(\mathrm{TeR}_{2}\right)_{2}\right](\mathrm{R}=\mathrm{Mes}, \mathrm{Ph}, \mathrm{o}$-tol $)$ with $\mathrm{MX}_{2}(\mathrm{M}=\mathrm{Pd}, \mathrm{Pt}) / \mathrm{Na}_{2} \mathrm{PdCl}_{4}$ (Scheme 7). ${ }^{93-95}$ These complexes were formed due to the chlorobridged cleavage reaction with the substitution of thio and seleoether through monotellurides. Usually, telluroether complexes are oriented in the cis form, which is slowly transformed to the trans isomer in solution. The conversion of the cis to the trans form was encountered in the ${ }^{125}$ TeNMR spectrum of the latter complexes, which exhibited a single resonance first, but in the longer acquisition results two prominent resonances were observed, attributed to the cis as well as trans forms. ${ }^{94}$ An agostic interaction between telluroethers and metal atoms has also been documented in these complexes, where a toluene-methanol solution of $\left[\mathrm{Pd}_{2} \mathrm{Cl}_{2}(\mu-\mathrm{Cl})_{2}\left(\mathrm{TeMes}_{2}\right)_{2}\right]$ or compound $\left[\mathrm{PdCl}_{2}(-\right.$ TeMes) $)_{2}$ ] on refluxing for $30 \mathrm{~min}$ yielded a binuclear cyclopalladated complex $\left[\mathrm{Pd}_{2}(\mu-\mathrm{Cl})_{2}\left\{\mathrm{CH}_{2} \mathrm{C}_{6} \mathrm{H}_{2}\left(4,6-\mathrm{Me}_{2}\right) \mathrm{TeMes}_{2}\right\}_{2}\right]$ (Scheme 7). However, the latter binuclear compound was converted to the mononuclear compound $\left[\mathrm{PdCl}_{2}\left\{\mathrm{MesTeCH}_{2} \mathrm{C}_{6}\right.\right.$ $\mathrm{H}_{2}\left(4,6-\mathrm{Me}_{2}\right)$ TeMes $\left.\}_{2}\right]$. The formation of the mononuclear compound mainly arose due to nucleophilic attack of mesityl tellurolate at the $\mathrm{Pd}-\mathrm{C}$ bond. ${ }^{93}$

Recently, an intricate palladacycle was synthesized by the reaction between ditolyl telluride and palladium acetate in toluene solution, which yielded two complexes with the composition $\left[(o \text {-tolylTe })_{2} \mathrm{OPd}(\mathrm{OAc})_{2}\right]$ (Fig. 5) and trinuclear $[\mathrm{Pd}(o \text {-tolyl })\{\text { di- } o \text {-tolyltelluride }\}]_{2} \mathrm{Pd}(\mu \text {-OAc })_{2}$. The former complex was a bidentate tellurinic acid anhydride, while the latter was coordinated to tolyl and telluride. ${ }^{96}$ The formation of both binuclear $\left[(o \text {-tolylTe })_{2} \mathrm{OPd}(\mathrm{OAc})_{2}\right]$ and trinuclear $[\mathrm{Pd}(o \text {-tolyl })\{\text { di- } o \text {-tolyltelluride }\}]_{2} \mathrm{Pd}(\mu \text {-OAc })_{2}$ complexes can be encountered by intramolecular cyclopalladation via the bond formation between palladium metal centers and tolyl carbon.

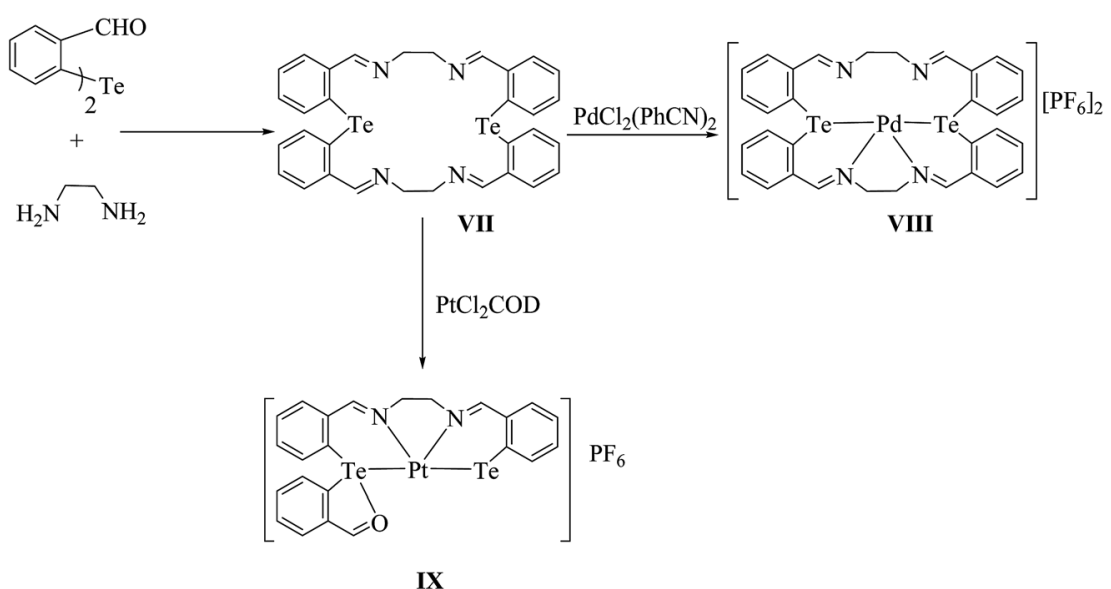

Scheme 6 Reaction of $\left[\mathrm{MCl}_{2}(\mathrm{~L})_{2}\right](\mathrm{M}=\mathrm{Pd}, \mathrm{Pt} ; \mathrm{L}=\mathrm{PhCN}$ or COD) with a tellurium-ligated macrocyclic Schiff base.

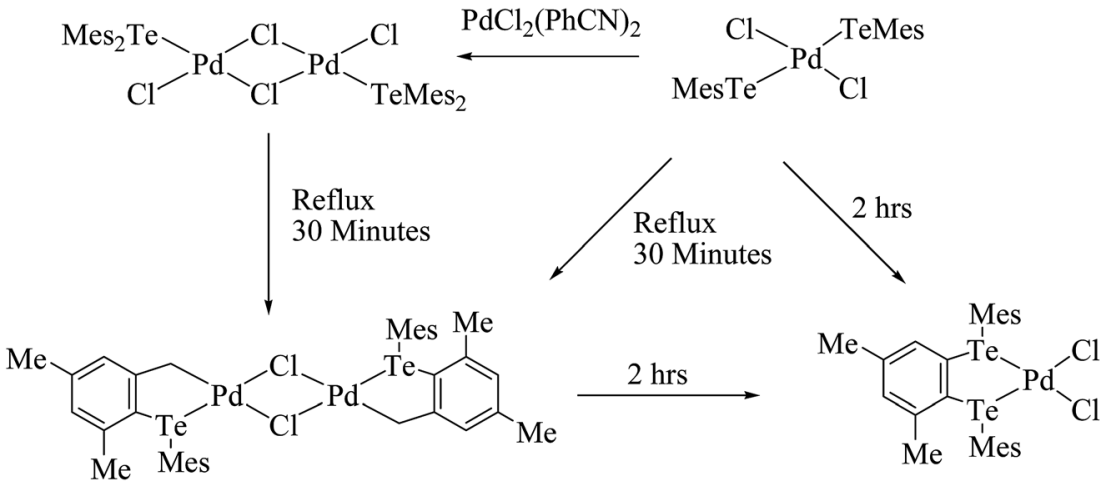

Scheme 7 Cyclometallation of $\left[\mathrm{PdCl}_{2}(\mathrm{Mes})_{2}\right]$ at different temperatures. 


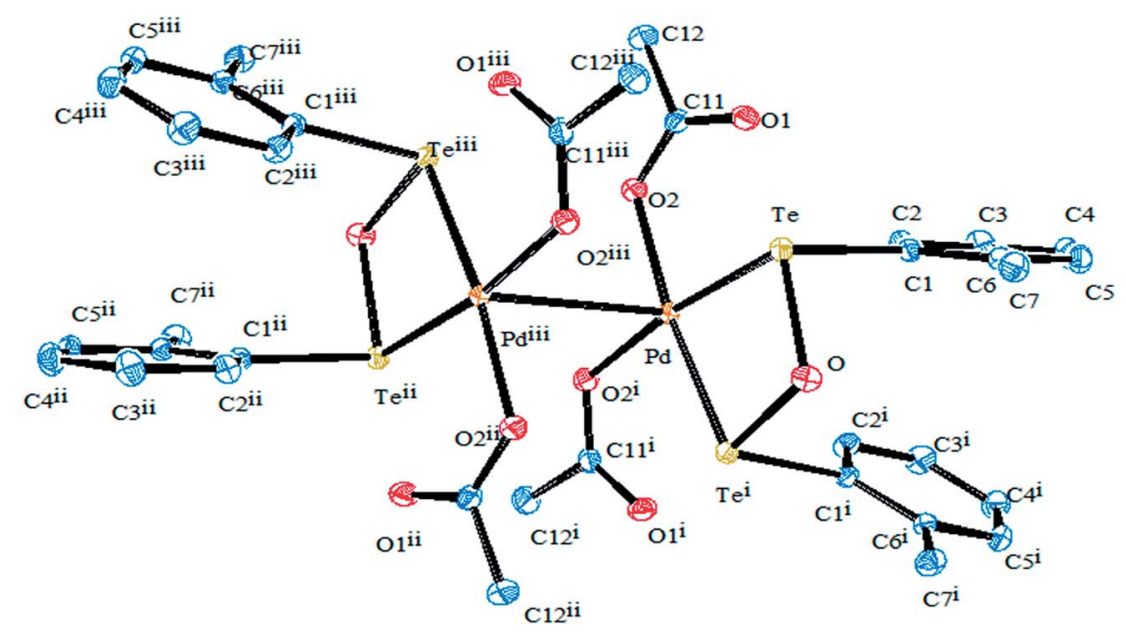

Fig. 5 Crystal structure of [(o-tolylTe $\left.)_{2} \mathrm{OPd}(\mathrm{OAc})_{2}\right]$ (redrawn from ref. 96).

\section{Metal tellurolates}

\subsection{Ruthenium and osmium}

The coordination chemistry of ruthenium cluster complexes toward the highly reactive organotellurium ligand is very rich in the literature, but still various aspects of its reactivity pattern are uncultivated. With this prospect, the refluxing of $\mathrm{Ru}_{3}(\mathrm{CO})_{12}$ with $\mathrm{Na}_{2} \mathrm{Te}_{2}$ and $\mathrm{PPh}_{4} \mathrm{PBr}$ at $80-130{ }^{\circ} \mathrm{C}$ for $8 \mathrm{~h}$ yielded the cluster complex $\left[\mathrm{Ru}_{4}(\mathrm{Te})_{2}\left(\mathrm{Te}_{2}\right)_{2}(\mathrm{TeMe})_{2}(\mathrm{CO})_{8}\right]\left(\mathrm{PPh}_{4}\right)_{2} \cdot{ }^{97} \quad$ The crystal structure of the latter complex consisted of four rectangles with a center of inversion in the midst. While the oxidative addition of diorganoditelluride to $\left[\mathrm{Ru}_{3}(\mathrm{CO})_{12}\right]$ yielded a variety of compounds. In particular, the reaction of diphenyl ditelluride resulted in the formation of a binuclear complex bridged by phenyl tellurolate along with the polymeric form of $\left[\mathrm{Ru}(\mathrm{CO})_{2}(\mu-\right.$ $\mathrm{TePh})]_{n} \cdot{ }^{\mathbf{9 8 , 9 9}}$ Performing the same reaction with the addition of halogen yielded the complex $\left[\mathrm{Ru}_{2} \mathrm{X}_{2}(\mathrm{CO})_{6}(\mu-\mathrm{TePh})_{2}\right](\mathrm{X}=\mathrm{Br}, \mathrm{I})$, which was isolated by breaking of the $\mathrm{Ru}-\mathrm{Ru}$ bond. ${ }^{99}$ Similarly, on refluxing a phosphine precursor of the ruthenium complex $\left[\mathrm{Ru}_{3}(\mathrm{CO})_{10}(\mu-\mathrm{dppm})\right]$ with tetrahydrofuran solution of $\mathrm{Ar}_{2} \mathrm{Te}_{2}$ $\left(\mathrm{Ar}=\mathrm{C}_{6} \mathrm{H}_{4} \mathrm{OEt}-4\right)$ in a $1: 2$ mole ratio for $6 \mathrm{~h}$ yielded a mixture of the products $\left[\mathrm{Ru}_{2}(\mathrm{CO})_{4}(\mu \text {-TeAr })_{2}(\mu\right.$-dppm $\left.)\right],\left[\mathrm{Ru}_{2}(\mathrm{CO})_{6}(\mu-\mathrm{TeAr})_{2}\right]$ and $\left[\mathrm{Ru}(\mathrm{CO})_{4}(\mathrm{TeAr})_{2}\right]$ (Scheme 8). ${ }^{\mathbf{1 0 0}}$ However in toluene solution, other than $\left[\mathrm{Ru}_{2}(\mathrm{CO})_{4}(\mu-\mathrm{TeAr})_{2}(\mu\right.$-dppm $\left.)\right]$, several products $^{101}$ have been afforded due to the competitive cleavage of Te-Te and Te-C bonds. At room temperature in $\mathrm{CH}_{2} \mathrm{Cl}_{2}$, reaction with a diphenyl ditelluride ligand system yielded the binuclear compound $\left[\mathrm{Ru}_{2}(\mu-\mathrm{TePh})_{2}(\mathrm{CO})_{4}(\mu-\mathrm{dppm})\right]$ as well as the trinuclear unsaturated clusters $\left[\mathrm{Ru}_{3}\left(\mu_{3}-\mathrm{Te}\right)_{2}(\mu-\mathrm{TePh})_{2}(\mathrm{CO})_{6}(\mu-\mathrm{dppm})\right]$ and $\left[\mathrm{Ru}_{2}\left(\mu_{3}-\mathrm{Te}\right)(\mu-\mathrm{TePh})_{3}(\mathrm{CO})_{6}\left(\eta^{1}-\mathrm{COPh}\right)(\mu-\mathrm{dppm})\right] .^{\mathbf{1 0 2}}$

Heating a solution of $\left[\mathrm{Ru}_{3}(\mu-\mathrm{H})\left\{\left(\mu_{3}-\eta^{2}-\mathrm{C}_{4} \mathrm{H}_{2} \mathrm{O}\right)\left(\mu-\mathrm{PC}_{4} \mathrm{H}_{3}-\right.\right.\right.$ $\left.\mathrm{O})_{2}\right\}(\mathrm{CO})_{7}(\mu$-dppm $\left.)\right]$ with $\mathrm{Ph}_{2} \mathrm{Te}_{2}$ at $110{ }^{\circ} \mathrm{C}$ for $2 \mathrm{~h}$ resulted in various cluster complexes, mainly $\left[\mathrm{Ru}_{3}\left(\mu_{3}-\mathrm{Te}\right)_{2}(\mu-\mathrm{TePh})_{2}\right.$ $\left.(\mathrm{CO})_{6}(\mu-\mathrm{dppm})\right], \quad\left[\mathrm{Ru}_{3}\left(\mu_{3}-\eta^{2}-\mathrm{C}_{4} \mathrm{H}_{3} \mathrm{O}\right)\left\{\mu-\mathrm{PC}_{4} \mathrm{H}_{3} \mathrm{O}_{2}\right\}(\mathrm{CO})_{5}(\mu-\mathrm{TePh})_{2}\right.$ $(\mu$-dppm) $]$ (Fig. 6), $\left[\mathrm{Ru}_{3}(\mu-\mathrm{H})\left(\mu_{3}-\eta^{2}-\mathrm{C}_{4} \mathrm{H}_{2} \mathrm{O}\right)\left\{\mu-\mathrm{C}_{4} \mathrm{H}_{3} \mathrm{O}_{2}\right\}(\mathrm{CO})_{5}\right.$ $\left.(\mu-\mathrm{TePh}) 2\left(\kappa^{2}-\mathrm{dppm}\right)\right]$, and $\left[\mathrm{Ru}_{3}(\mu-\mathrm{H})\left(\mu_{3}-\eta^{2}-\mathrm{C}_{4} \mathrm{H}_{2} \mathrm{O}\right)\left\{\left(\mathrm{PC}_{4} \mathrm{H}_{3} \mathrm{O}\right)_{3}\right\}\right.$ $\left\{\mu-\mathrm{P}\left(\mathrm{C}_{4} \mathrm{H}_{3} \mathrm{O}\right)_{2}\right\}(\mathrm{CO})_{4}(\mu-\mathrm{TePh})_{2}\left(\kappa^{2}\right.$-dppm $\left.)\right]{ }^{103}$ However, the reaction of the tetranuclear ruthenium(II) complex with $\mathrm{R}_{2} \mathrm{Te}_{2}(\mathrm{R}=$
$\mathrm{Me}, \mathrm{Et}, \mathrm{Fc})$ yielded the diruthenium complex syn-[Cp* RuCl $(\mu-\mathrm{TeR})]_{2}$ in quite a good yield. ${ }^{\mathbf{1 0 4}}$ Although the reaction of dialkylditellurides led to a clean pot synthesis of alkanechalcogenolate diruthenium complex, in the case of phenyl derivatives of the tellurium-ligated system, two products $[\mathrm{Cp} * \mathrm{RuCl}(\mu-\mathrm{TePh})]_{2}$ and $\left[\mathrm{Cp} * \mathrm{Ru}(\mu-\mathrm{TePh})_{3} \mathrm{RuCp}{ }^{*}\right] \mathrm{Cl}$ were isolated. ${ }^{104}$

Treatment of $\left[\left(\eta^{6}\right.\right.$-cymene $\left.) \mathrm{Ru}(\mu-\mathrm{Cl})_{3} \operatorname{Re}(\mathrm{CO})_{3}\right]$ with sodium salt phenyl telluride yielded a yellow heterometallic product $\left[\left(\eta^{6}\right.\right.$-cymene $\left.) \mathrm{Ru}(\mu-\mathrm{TePh})_{3}\right]\left[\operatorname{Re}_{2}(\mathrm{CO})_{6}(\mu-\mathrm{TePh})_{3}\right] \cdot{ }^{105}$ Half sandwich complex $\left[(\mathrm{Cp} * \mathrm{Ru})_{2} \mathrm{~B}_{2} \mathrm{H}_{6}(\mu-\mathrm{TePh})\right]$ has been obtained by the thermolysis of $\left[(\mathrm{Cp} * \mathrm{Ru})_{2} \mathrm{~B}_{2} \mathrm{H}_{6} \mathrm{~S}_{2}\right]$ in the presence of $\mathrm{Ph}_{2} \mathrm{Te}_{2}{ }^{106}$ The reactions of $\left[\mathrm{Fe}_{2}(\mu-\mathrm{Te})_{2}(\mathrm{CO})_{6}\right]$ with low valent precursor of ruthenium metal derive heteronuclear telluride bridged cluster compound by the insertion between the Te-Te bond. ${ }^{107-112}$ Therefore the treatment of $\left[\mathrm{Ru}_{4}(\mathrm{CO})_{12}\right]$ with $\left[\mathrm{Fe}_{2}(\mu-\mathrm{Te})_{2}(\mathrm{CO})_{6}\right]$ afforded a pentanuclear cluster complex of composition $\left[\mathrm{Fe}(\mathrm{CO})_{6} \mathrm{Ru}_{3}(\mu-\mathrm{Te})_{2}(\mathrm{CO})_{11}\right]{ }^{107}$ Similar outcome has been obtained by the reaction of $\left[\mathrm{Fe}_{2}\left(\mu-\mathrm{EE}^{\prime}\right)_{2}(\mathrm{CO})_{6}\right](\mathrm{E}=\mathrm{S}, \mathrm{Se}, \mathrm{Te})$ with $\left[\mathrm{M}_{3}(\mathrm{CO})_{12}(\mathrm{NCMe})\right](\mathrm{M}=\mathrm{Ru}, \mathrm{Os}) \cdot{ }^{109,110}$ These latter complexes are also isolated at room temperature by the precursor $\left[\mathrm{M}_{3}(\mathrm{CO})_{10}(\mathrm{MeCN})_{2}\right](\mathrm{M}=\mathrm{Ru}, \mathrm{Os}) .{ }^{113}$ While the reaction with

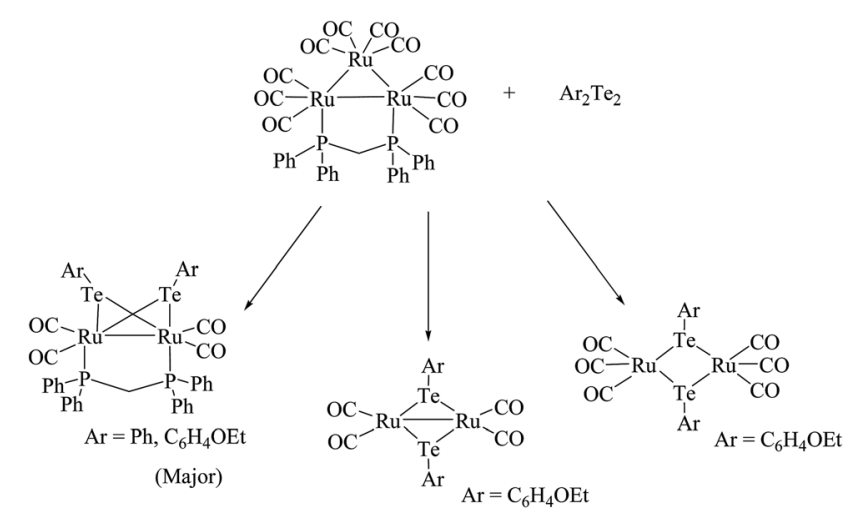

Scheme 8 Oxidative addition of $\left[\mathrm{Ru}_{3}(\mathrm{CO})_{10}(\mu-\mathrm{dppm})\right]$ with diaryl ditelluride. 


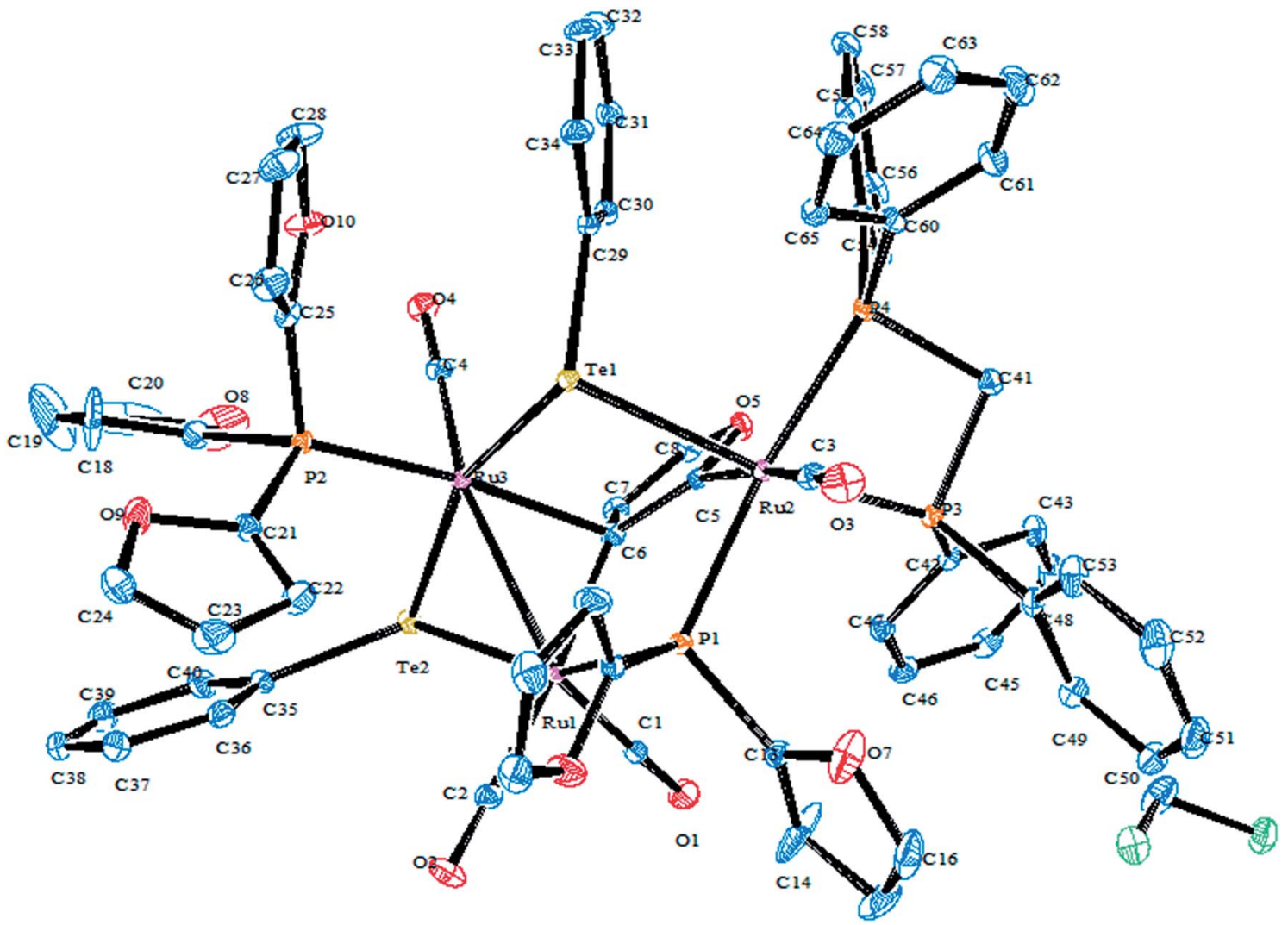

Fig. 6 Crystal structure of $\left[R u_{3}\left(\mu_{3}-\eta^{2}-\mathrm{C}_{4} \mathrm{H}_{3} \mathrm{O}\right)\left\{\left(\mu-\mathrm{PC}_{4} \mathrm{H}_{3} \mathrm{O}\right)_{2}\right\}(\mathrm{CO})_{5}(\mu-\mathrm{TePh})_{2}(\mu-\mathrm{dppm})\right]$ (redrawn from ref. 103).

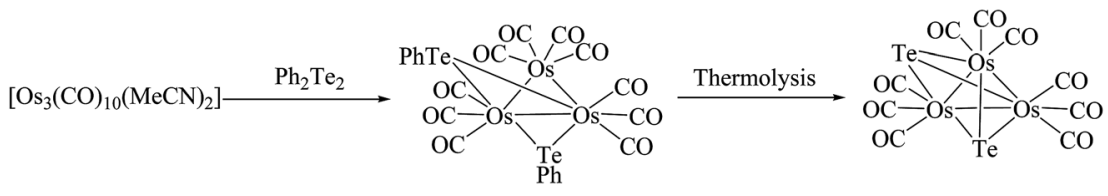

Scheme 9 Synthesis of a trinuclear osmium telluride bridged complex.

trinuclear compound $\left[\mathrm{Fe}_{3}\left(\mu_{3}-\mathrm{Te}\right)_{2}(\mathrm{CO})_{9}\right]$ results the substitution product $\left[\mathrm{Ru}_{4}\left(\mu_{4}-\mathrm{Te}\right)_{2}(\mathrm{CO})_{11}\right]^{114}$

In contrast to ruthenium, the reaction of $\mathrm{Ph}_{2} \mathrm{Te}_{2}$ with the osmium precursor $\left[\mathrm{Os}_{3}\left(\mathrm{CH}_{3} \mathrm{CN}\right)_{2}(\mathrm{CO})_{10}\right]$ under normal conditions yielded the cluster $\left[\mathrm{Os}_{3}(\mathrm{CO})_{10}(\mu \text {-TePh })_{2}\right]$, in which both tellurium linkages were at opposite Os-Os edges. ${ }^{115}$ Thermolysis of the latter complex resulted in the cleavage of $\mathrm{Te}-\mathrm{C}$ bonds and yielded the product $\left[\mathrm{Os}_{3}(\mathrm{CO})_{9}(\mu-\mathrm{Te})_{2}\right]$ (Scheme 9). ${ }^{116}$ Different to the selenium analog, in this case there was no evidence of intact REER bonds in these complexes, but the conversion from one isomer to other isomer is much more facile; while the reaction with unsaturated osmium cluster compounds, like $\left[\mathrm{Os}_{3}\right.$ $\left.(\mu-\mathrm{H})_{2}(\mathrm{CO})_{10}\right]$, are much more complicated. A variety of complexes were formed, out of which three cluster complexes, namely $\left[\mathrm{Os}_{3} \mathrm{H}_{2}(\mu-\mathrm{TePh})_{2}(\mathrm{CO})_{10}\right](\mathbf{X}),\left[\mathrm{Os}_{3} \mathrm{H}(\mu-\mathrm{TePh})(\mathrm{CO})_{10}\right](\mathbf{X I})$, and $\left[\mathrm{OsH}(\mathrm{CO})_{3}(\mathrm{TePh})\right]_{2}{ }^{115}$ were isolated. The same ligand upon reaction with phosphine-derived osmium precursors yielded the binuclear product $\left[\mathrm{Os}_{2}(\mu-\mathrm{TePh})_{2}(\mathrm{CO})_{4}(\mu-\mathrm{dppm})\right]$ and two isomeric compounds with the composition $\left[\mathrm{Os}_{3}(\mu-\mathrm{TePh})_{2}\right.$
$\left.(\mathrm{CO})_{8}(\mu-\mathrm{dppm})\right]$ (Fig. 7), which mainly differ from the phenyl orientation attached to the telluride metal center. ${ }^{116}$

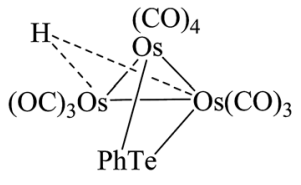

$\mathbf{X}$

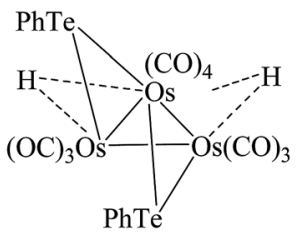

XI
A very close output was obtained when performing the oxidative addition reaction of $(\mathrm{TeTol})_{2}$ with the mixed cluster $\left[\mathrm{Cp}^{*} \operatorname{IrOs}_{3}(\mu-\mathrm{H})_{2}(\mathrm{CO})_{10}\right] \cdot{ }^{117}$ In this case, three cluster complexes were isolated with the composition $\left[\mathrm{Cp}^{*} \operatorname{IrOs}_{3}(\mu-\mathrm{H})_{2}(\mu \text {-Tetol })_{2}\right.$ $\left.(\mathrm{CO})_{7}\right]$ (Fig. 8). These clusters had relatively different orientations of the tolyl group around the tellurium center, with two of them being stereoisomers having the tolyl group orientation away from the cluster core, i.e., exo, or inward toward the core, i.e., endo. These possibilities of obtaining various stereoisomers 


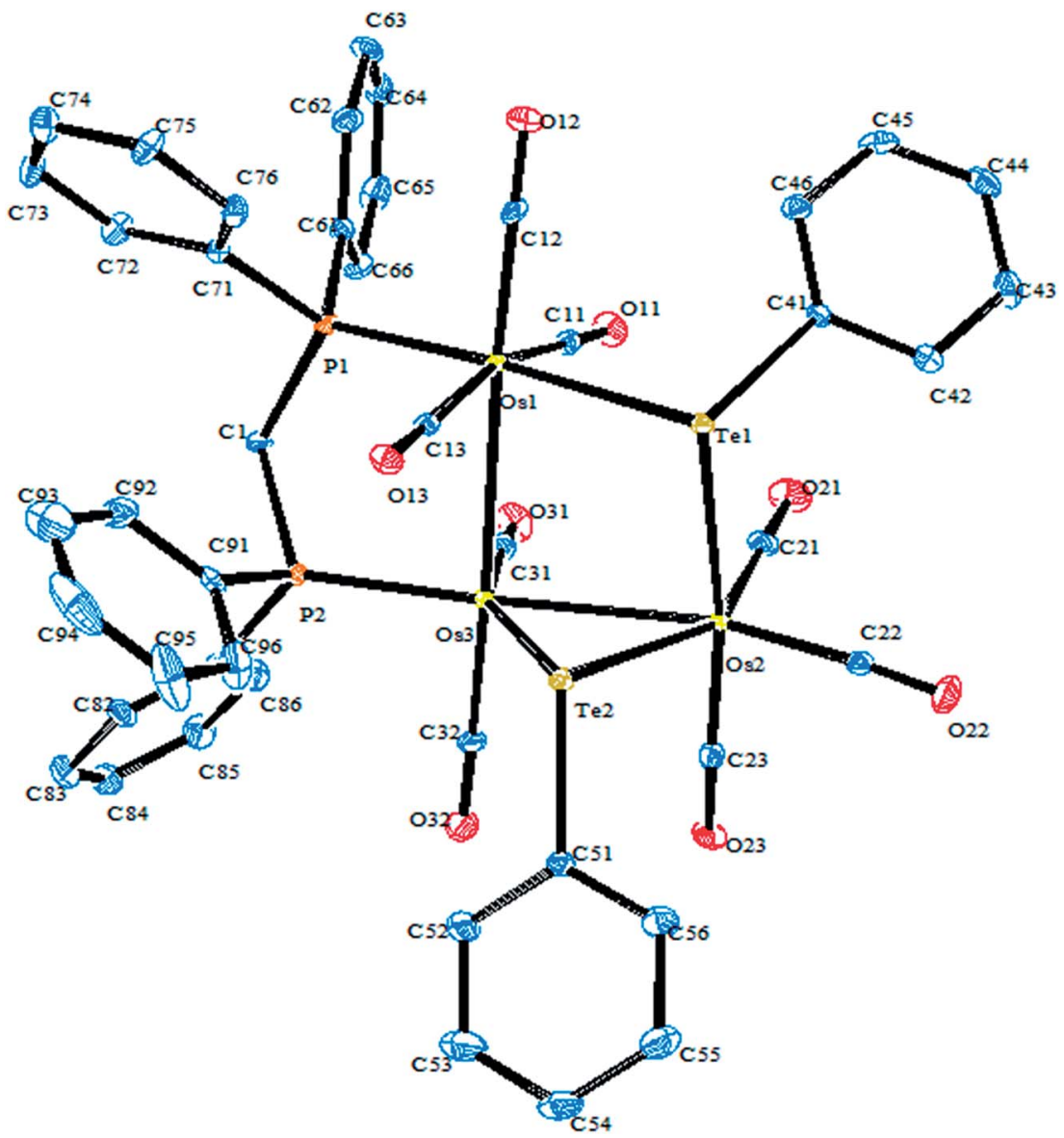

Fig. 7 Crystal structure of $\left[\mathrm{Os}_{3}(\mu-\mathrm{TePh})_{2}(\mathrm{CO})_{8}(\mu\right.$-dppm)] (redrawn from ref. 116).

have only been reported in ditellurides systems, and can be encountered due to the dynamic nature of tellurium lone pairs. ${ }^{117}$

\subsection{Rhodium and iridium}

A new class of rhodium precursors, like [Tp* $\mathrm{Rh}(\mathrm{COE})(\mathrm{MeCN})]$ $\left(\mathrm{Tp}^{*}=\right.$ hydrotris $(3,5$ dimethylpyrazol-1-yl)borate; $\mathrm{COE}=$ cyclooctene), were explored to study the oxidative addition reaction with diphenyl ditelluride. ${ }^{118}$ The latter reaction mixture resulted in an oxidative additive product, namely $\left[\mathrm{Tp} * \mathrm{Rh}(\mathrm{TePh})_{2}\right.$ $(\mathrm{MeCN})]$, which was allowed to react further with a small amount of $\left[(\mathrm{Cp} * \mathrm{Ru})_{4}\left(\mu_{3}-\mathrm{Cl}\right)_{4}\right]$ to yield the mixed binuclear compound $\left[\mathrm{Tp} * \operatorname{RhCl}(\mu-\mathrm{TePh})_{2} \mathrm{RuCp} *\left(\mathrm{CH}_{3} \mathrm{CN}\right)\right]$. However, on stirring the reaction mixture in an open atmosphere, it binds with oxygen to result in the complex $\left[\left(\mathrm{Tp} * \operatorname{RhCl}(\mu-\mathrm{TePh})_{2}\right.\right.$ RuCp* $\left.\left.\mathrm{O}_{2}\right)\right]$. The reaction of $\left[\left(\mathrm{Cp}^{*}\right)_{2} \mathrm{Rh}_{2}(\mu-\mathrm{CO}) \mu-\eta^{2}: \eta^{2} \mathrm{C}_{2}\left(\mathrm{CF}_{3}\right)_{2}\right]$ with $\mathrm{R}_{2} \mathrm{Te}_{2}\left(\mathrm{R}=\mathrm{Me}\right.$, Et, $\left.{ }^{i} \mathrm{pr}, \mathrm{Ph}, \mathrm{Fc}\right)$ yielded the product $\left[\left(\mathrm{Cp}^{*}\right)_{2} \mathrm{Rh}(\mu-\mathrm{TeR})_{2}\left\{\mu-\mathrm{C}_{2}\left(\mathrm{CF}_{3}\right)_{2}\right\}\right]^{119,120}$ (Scheme 10) along with some of the product $\left[\left(\mathrm{Cp}^{*}\right)_{2} \mathrm{Rh}(\mu-\mathrm{TeR})_{2}\left\{\mu-\mathrm{CO}\left(\mathrm{CCF}_{3}\right)_{2}\right\}\right]$ formed $v i a$ the insertion process. A new class of internally functionalized dianion ligands $\left[\mathrm{Te}\left({ }^{t} \mathrm{BuN}\right) \mathrm{P}\left(\mu^{t} \mathrm{BuN}\right) 2 \mathrm{P}(\mathrm{NtBu}) \mathrm{Te}\right]^{2-}$ upon reaction with $\left[\mathrm{Cp}^{*} \mathrm{Rh}_{2}\left(\mu-\mathrm{Cl}_{2} \mathrm{Cl}_{2}\right]\right.$ afforded a cyclic compound with the composition $\left[\mathrm{Cp} * \mathrm{Rh}\left\{{ }^{t} \mathrm{BuN}(\mathrm{Te}) \mathrm{P}\left(\mu-\mathrm{N}^{t} \mathrm{Bu}\right)_{2} \mathrm{P}(\mathrm{Te}) \mathrm{NBu}^{t}\right\}_{2}(\mu-\mathrm{Te})\right] .{ }^{121}$

The reaction of iridium carbonyl clusters with diphenyl ditelluride is very selective with a very sluggish rate, requiring
$20 \mathrm{~h}$ of continuous stirring to complete the reaction. The refluxing of $\mathrm{PhTeTePh}$ and $\left[\mathrm{Ir}_{6}(\mathrm{CO})_{15}\right]^{2-}$ gave the anionic cluster $\left[\operatorname{Ir}_{6}(\mathrm{CO})_{14}(\mu-\mathrm{TePh})\right]^{-}$in tetrahydrofuran solution. ${ }^{122}$ By applying the same experimental conditions with a $2: 1.5$ mole ratio of PhTeTePh with $\left[\operatorname{Ir}_{6}(\mathrm{CO})_{15}\right]^{2-}$ yielded exclusively the neutral product $\left[\operatorname{Ir}_{6}(\mathrm{CO})_{13}(\mu-\mathrm{TePh})_{2}\right]$; however, similar reactions with other chalcogenides yielded a mixture of products in which a similar neutral product was isolated in very poor yield via a solvent extraction methodology. The best strategy applied to isolate the above neutral complex was the reaction of $\left[\operatorname{Ir}_{6}(\mathrm{CO})_{16}\right]$ with $\mathrm{PhTeTePh}$ in refluxing toluene. The same reaction with other chalcogenides was much less effective in terms of isolation of the cluster compound (Scheme 11). ${ }^{122}$

In an attempt to synthesize hyper-valent iridium complexes, organotellurium compounds have played a key role to isolate such complexes. In this context, an oxidative addition of $\mathrm{Ph}_{2} \mathrm{Te}_{2}$ with the $\operatorname{Ir}(\mathrm{I})$ compound $[\mathrm{Cp} * \operatorname{Ir}(\mathrm{ppy})(\text { solv })]^{+}$was applied. ${ }^{123}$ Surprisingly the reaction led to the formation of the $\operatorname{Ir}(\mathrm{III})$ $\eta^{1}$-ditelluride complex [Cp* $\left.\operatorname{Ir}(\mathrm{ppy})\left(\eta^{1}-\mathrm{Te}_{2} \mathrm{Ph}_{2}\right)\right](\mathrm{OTf})$. It is noteworthy that isolation of a complex with the coordination mode $\eta^{1}$-REER is very much less common, e.g. $\left[\mathrm{Cp} * \mathrm{Mn}(\mathrm{CO})_{2}\right]_{2}\left(\mu-\eta^{1}\right.$-REER $),{ }^{124}$ but it is strongly believed that these coordination modes derived compounds take part as an intermediate in the oxidative addition of $\mathrm{R}_{2} \mathrm{E}_{2}(\mathrm{E}=\mathrm{S}, \mathrm{Se}, \mathrm{Te})$ to give the $\operatorname{Pd}(0)$ and $\mathrm{Pt}(0)$ precursors. ${ }^{125}$ The proven potency from the dynamic nature of tellurium metal can be encountered with 


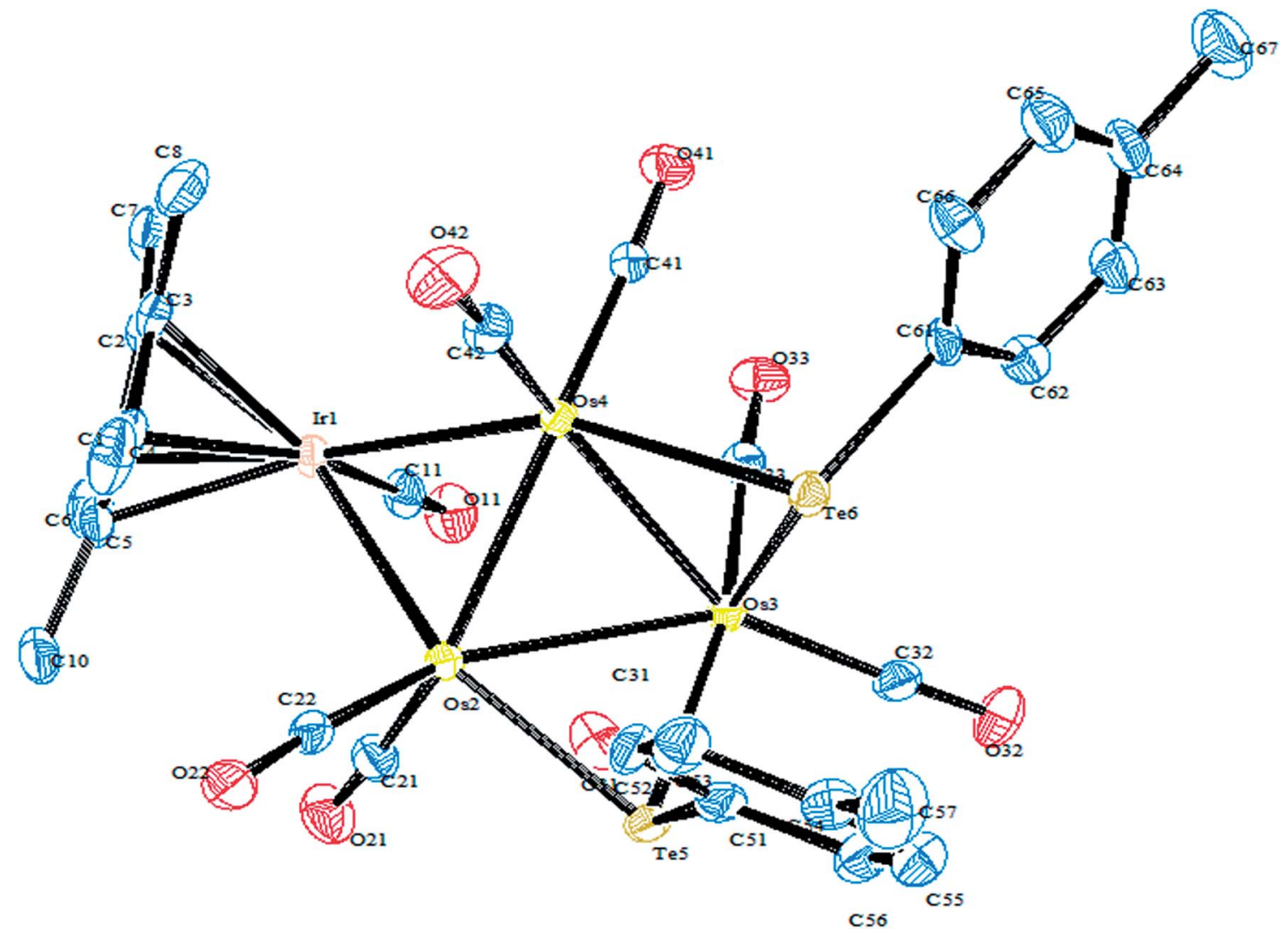

Fig. 8 Crystal structure of $\left[\mathrm{Cp} * \mid \mathrm{rOs}_{3}(\mu-\mathrm{H})_{2}(\mu-\mathrm{Tetol})_{2}(\mathrm{CO})_{7}\right]$ (redrawn from ref. 117).

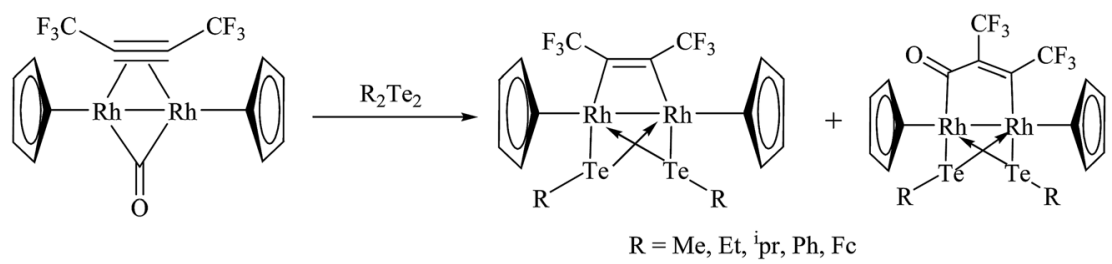

Scheme 10 Reaction of $\left[(C p *)_{2} R h_{2}(\mu-C O) \mu-\eta^{2}: \eta^{2} C_{2}\left(C_{3}\right)_{2}\right]$ with $R_{2} T e_{2}\left(R=M e, E t,{ }^{i} p r, P h, F c\right)$.

the ease of synthesis of homo- and heterometallic complexes with iridium compounds derived from the tellurolate ligand system. As an example, the oxidative addition product $\left[\mathrm{Cp} * \mathrm{Ir}(\mathrm{CO})(\mathrm{TeTol})_{2}\right]$ upon reaction with $\left[(\mathrm{Cp} * \mathrm{MCl})_{2}(\mu-\mathrm{Cl})_{2}\right](\mathrm{M}=$ $\mathrm{Rh}$, Ir) yielded a stereoisomer of the binuclear complexes $\left[\mathrm{Cp} * \mathrm{Ir}(\mathrm{CO})(\mu-\mathrm{TeTol})_{2} \mathrm{MCp} * \mathrm{Cl}\right] \mathrm{Cl}(\mathrm{M}=\mathrm{Rh}, \mathrm{Ir})($ Fig. 9) bridged with telluride systems (Scheme 12). Interestingly, a similar reaction of $\left[\mathrm{Cp} * \operatorname{Ir}(\mathrm{CO})(\mathrm{TeTol})_{2}\right]$ with $\left[\mathrm{Cp}^{*} \mathrm{RuCl}_{4}\left(\mu_{3}-\mathrm{Cl}\right)_{4}\right]$ and

$$
\begin{aligned}
& {\left[\mathrm{Ir}_{6}(\mathrm{CO})_{15}\right]^{2-}+\mathrm{PhTeTePh} \longrightarrow\left[\mathrm{Ir}_{6}(\mathrm{CO})_{14}(\mu-\mathrm{TePh})\right]^{-}} \\
& {\left[\mathrm{Ir}_{6}(\mathrm{CO})_{16}\right]+\mathrm{PhTeTePh} \longrightarrow\left[\mathrm{Ir}_{6}(\mathrm{CO})_{13}(\mu-\mathrm{TePh})_{2}\right]+3 \mathrm{CO}} \\
& 2\left[\operatorname{Ir}(\mathrm{CO})_{15}\right]^{-}+\mathrm{PhTeTePh} \longrightarrow 2\left[\operatorname{Ir}_{6}(\mathrm{CO})_{14}(\mathrm{TePh})\right]^{-}
\end{aligned}
$$

Scheme 11 Oxidative addition reactions of diphenylditellurides with iridium carbonyl clusters.
$\left[\mathrm{RuH}(\mathrm{COD})\left(\mathrm{CH}_{3} \mathrm{CN}\right)\right]\left(\mathrm{BPh}_{4}\right)$ resulted in the formation of the tetranuclear $\left[\mathrm{Cp} * \operatorname{IrCl}\left\{\mu-\mathrm{Te}\left(\eta^{6}-\mathrm{Tol}\right) \mathrm{RuCp} *\right]_{2} \mathrm{RuCp}^{*}(\mathrm{CO})\right] \mathrm{Cl}_{2}$ and binuclear $\left[\mathrm{Cp} * \operatorname{Ir}(\mu-\mathrm{H})(\mu-\mathrm{TeTol})_{2} \mathrm{Ru}(\mathrm{CO})(\mathrm{COD})\right] \mathrm{BPh}_{4}$ complexes, respectively (Scheme 12). ${ }^{126}$

\subsection{Palladium and platinum}

Tellurium complexes with palladium and platinum phosphine precursors are comparatively more stable than any other precursors. The main stability factor is the $\pi$ bonding involving $\mathrm{d}_{\mathrm{xy}}$ orbitals of the palladium and platinum metals with the available empty orbitals of phosphine, which results in the extent of $\sigma$ overlapping being stronger in the phosphine complexes. ${ }^{127,128}$ Hence, these complexes play a crucial role in a reduction of the electron density around the metal center, which is enhanced due to the ease of donation of the lone pair available on the tellurium center. 


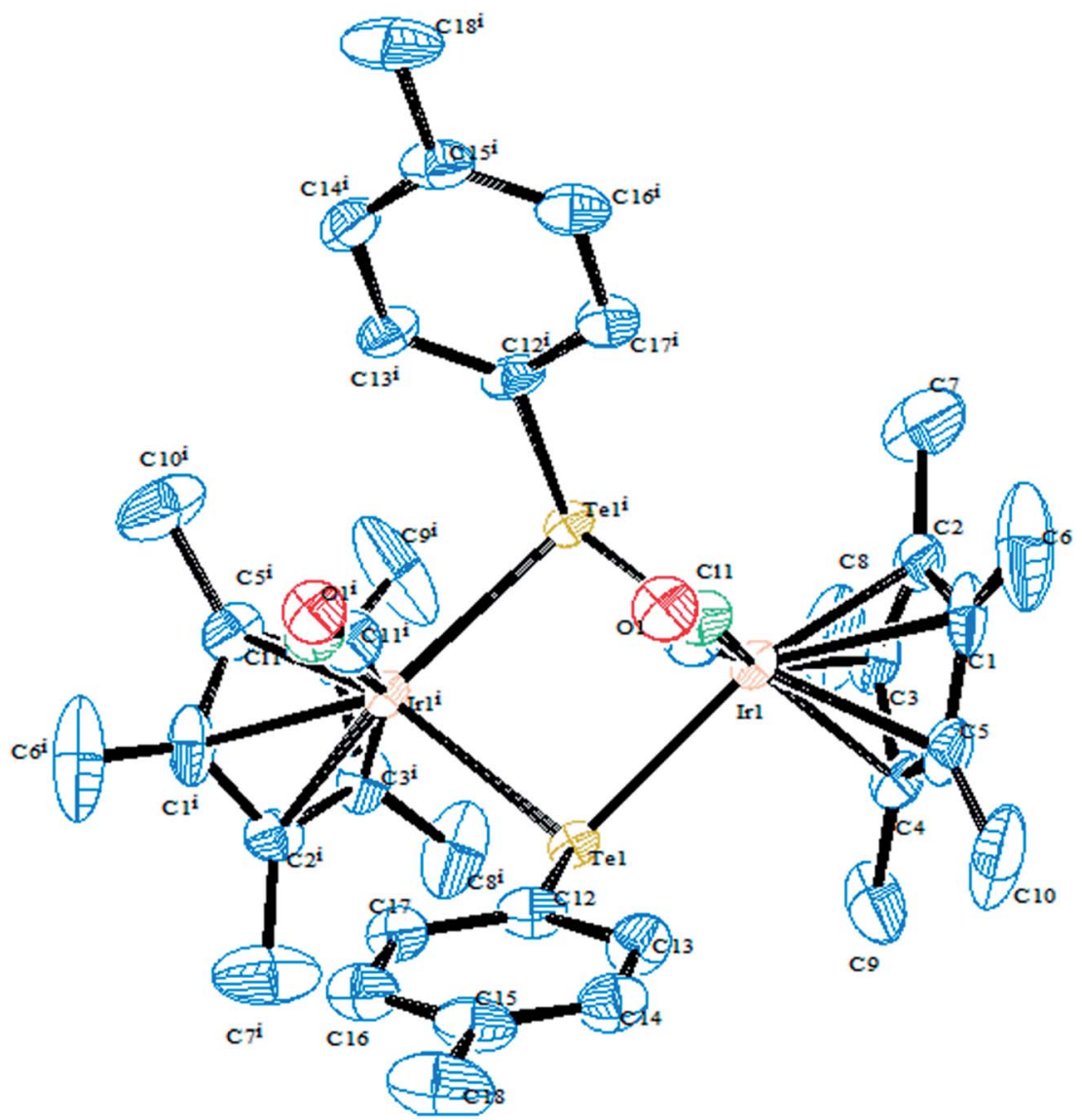

Fig. 9 Crystal structure of $\left[\mathrm{Cp} * \operatorname{lr}(\mathrm{CO})(\mu-\mathrm{TeTol})_{2} \mid \mathrm{rCp} * \mathrm{Cl}\right]$ (redrawn from ref. 126).

4.3.1. Reactivity of various tellurium systems with palladium and platinum nonchelated phosphine precursors. T. B. Rauchfuss and Rheingold synthesized a series of complexes of the type $\left[\mathrm{Pt}\left(\mathrm{ETeC}_{6} \mathrm{H}_{4}\right)\left(\mathrm{PPh}_{3}\right)_{2}\right](\mathrm{E}=\mathrm{S} ; \mathrm{Se}$; Te $)$ derived from ligand systems like alkeneditellurides and 1,2 benezeneditellurides, ${ }^{\mathbf{1 2 9}}$ which represent the first examples of mixed chalcogenides ligand systems (Scheme 15). Various complexes of the type $\left[\mathrm{MCl}\left\{\mathrm{TeC}_{5} \mathrm{H}_{3}\left(3-\mathrm{R}^{\prime}\right) \mathrm{N}\right\}\left(\mathrm{PR}_{3}\right)\right](\mathrm{M}=\mathrm{Pd}, \mathrm{Pt} ; \mathrm{R}$ $\left.=\mathrm{PEt}_{3}, \mathrm{Ph}_{2} \mathrm{Me}\right)$ have been derived by cleaving of the bond between metal bridged chlorides, e.g., the reaction of $\left[\mathrm{M}_{2} \mathrm{Cl}_{2}(\mu-\mathrm{Cl})_{2}\left(\mathrm{PR}_{3}\right)_{2}\right]\left(\mathrm{M}=\mathrm{Pd}, \mathrm{Pt} ; \mathrm{R}=\mathrm{PEt}_{3}, \mathrm{Ph}_{2} \mathrm{Me}\right)$ with two equivalent of $\mathrm{NaTe}\left(\mathrm{R}^{\prime} \mathrm{C}_{5} \mathrm{H}_{3} \mathrm{~N}\right)\left(\mathrm{R}^{\prime}=\mathrm{H}, \mathrm{Me}\right)$ (Scheme 13). ${ }^{\mathbf{1 3 0 , 1 3 1}}$

$$
\text { * }
$$

Scheme 12 Synthesis of various heterometallic complexes using $\left[\mathrm{Cp} * \operatorname{lr}(\mathrm{CO})(\mathrm{TeTol})_{2}\right]$. 


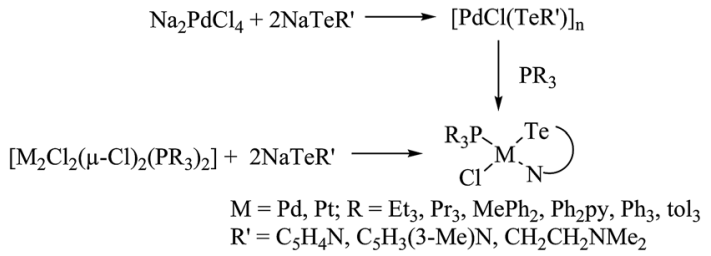

Scheme 13 Reactions of $\left[\mathrm{M}_{2} \mathrm{Cl}_{2}(\mu-\mathrm{Cl})_{2}\left(\mathrm{PR}_{3}\right)_{2}\right]$ with various sodium salts of tellurolate ligands.

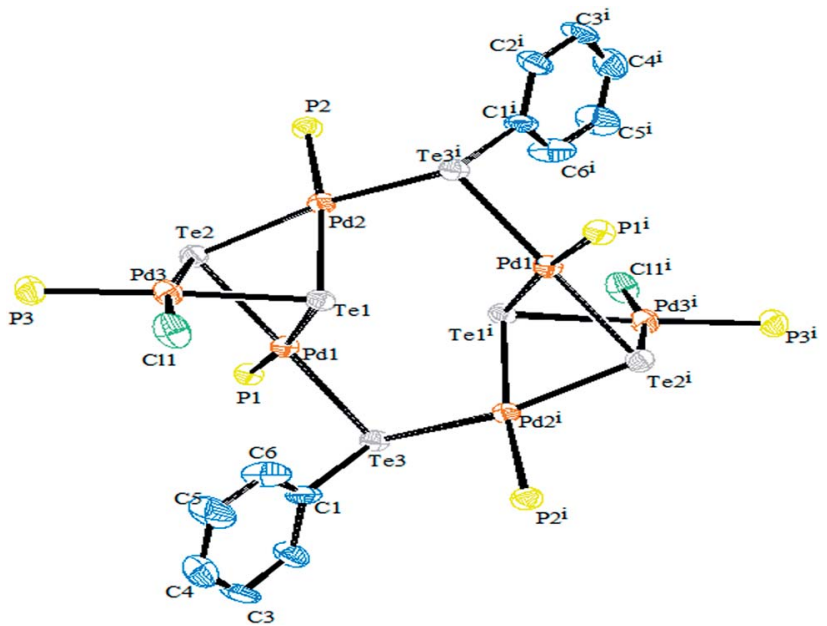

Fig. 10 Crystal structure of $\left[\mathrm{Pd}_{6} \mathrm{Te}_{6} \mathrm{Cl}_{2}\left(\mathrm{PEt}_{3}\right)_{6}\right]$ (redrawn from ref. 138).

Performing an oxidative addition reaction between $\left[\mathrm{Pd}\left(\mathrm{PPh}_{3}\right)_{4}\right]$ and various diaryl ditelluride ligand systems yielded binuclear products with the composition $\left[\operatorname{Pd}_{2}(\mu-\mathrm{TeAr})_{2}\right.$ $\left.(\mathrm{TeAr})_{2}\left(\mathrm{PPh}_{3}\right)_{2}\right] \cdot{ }^{132}$ In the latter complex, both terminal and bridging positions are occupied with aryl tellurols (Scheme 13).
On the other hand, an alike reaction upon performing with $\left[\mathrm{M}\left(\mathrm{PPh}_{3}\right)_{4}\right](\mathrm{M}=\mathrm{Pd}, \mathrm{Pt})$ with various ligand systems, such as $\mathrm{CF}_{3} \mathrm{Te}_{2} \mathrm{Th}_{2} \mathrm{Te}_{2}, \mathrm{Ph}_{2} \mathrm{Te}_{2}$, afforded mono-, bi-, tri-, and hexanuclear complexes $\left[\mathrm{Pd}_{6} \mathrm{Te}_{6} \mathrm{Cl}_{2}\left(\mathrm{PEt}_{3}\right)_{6}\right]$ (Fig. 10) depending on the nature of the solvent (Schemes 14 and 16)..$^{21,133-138}$ It has been well established that the bonding energy between $\mathrm{C}-\mathrm{Te}$ and Te-Te is quite comparable compared to other analogs of the chalcogen family, and therefore the reaction with tellurium ligands afforded polynuclear compounds. Tanaka et al. found that upon performing an oxidative addition between $\operatorname{Pd}(0)$ or $\operatorname{Pt}(0)$ species with various telluroethers, cleavage of the $\mathrm{C}$-Te bonds take place, leading to isolation of a compound with the composition $\left[\mathrm{M}(\mathrm{Ar})(\mathrm{TeAr})\left(\mathrm{PEt}_{3}\right)_{2}\right] \quad(\mathrm{M}=\mathrm{Pd}, \mathrm{Pt})$ (Scheme 14).22

Molecular orbital calculations also concluded that the activation energy barrier for the oxidative addition of dichlacogenides to $\left[\mathrm{M}\left(\mathrm{PH}_{3}\right)_{2}\right]$ decreases in the order $\mathrm{S}>\mathrm{Se}>\mathrm{Te}$ (in terms of the addition of E-E bonds). ${ }^{\mathbf{1 2 5}}$ Hence, the exothermicity of the reaction is also decreased with respect to the $\mathrm{M}-\mathrm{E}-\mathrm{R}$ bond strength. This statement quantifies that the oxidative addition of Te-Te bonds to low valent metal precursors is very simplistic compared to with the rest of the other dichalcogenides analogs and results in a complex (mononuclear) that is less stable compared to thiolato and selenolato complexes. However, the tendency for isolation of the dimerized product follows the reverse trend $(\mathrm{S}<\mathrm{Se}<\mathrm{Te})$. Therefore, it can easily be concluded that binuclear complexes are higher in tellurium system compared to the other analogs.

Recently, Jain et al. performed an oxidative addition among $\left[\mathrm{Pt}\left(\mathrm{PPh}_{3}\right)_{4}\right]$ and hemilabile pyridyl ditelluride $\left(\mathrm{C}_{5} \mathrm{H}_{4} \mathrm{~N}\right)_{2} \mathrm{Te}_{2}$ to isolate novel complexes with the composition $\left[\mathrm{Pt}\left\{\mathrm{TeC}_{5} \mathrm{H}_{3}(3-\mathrm{R})\right.\right.$ $\left.\mathrm{N}\}_{2} \mathrm{Te}\left(\mathrm{PPh}_{3}\right)\right](\mathrm{R}=\mathrm{H}, \mathrm{Me})$ (Scheme 16) along with an expected oxidative addition product. ${ }^{7}$ The former complex was the first example of its own type of tellurium (0) acting as a ligand system

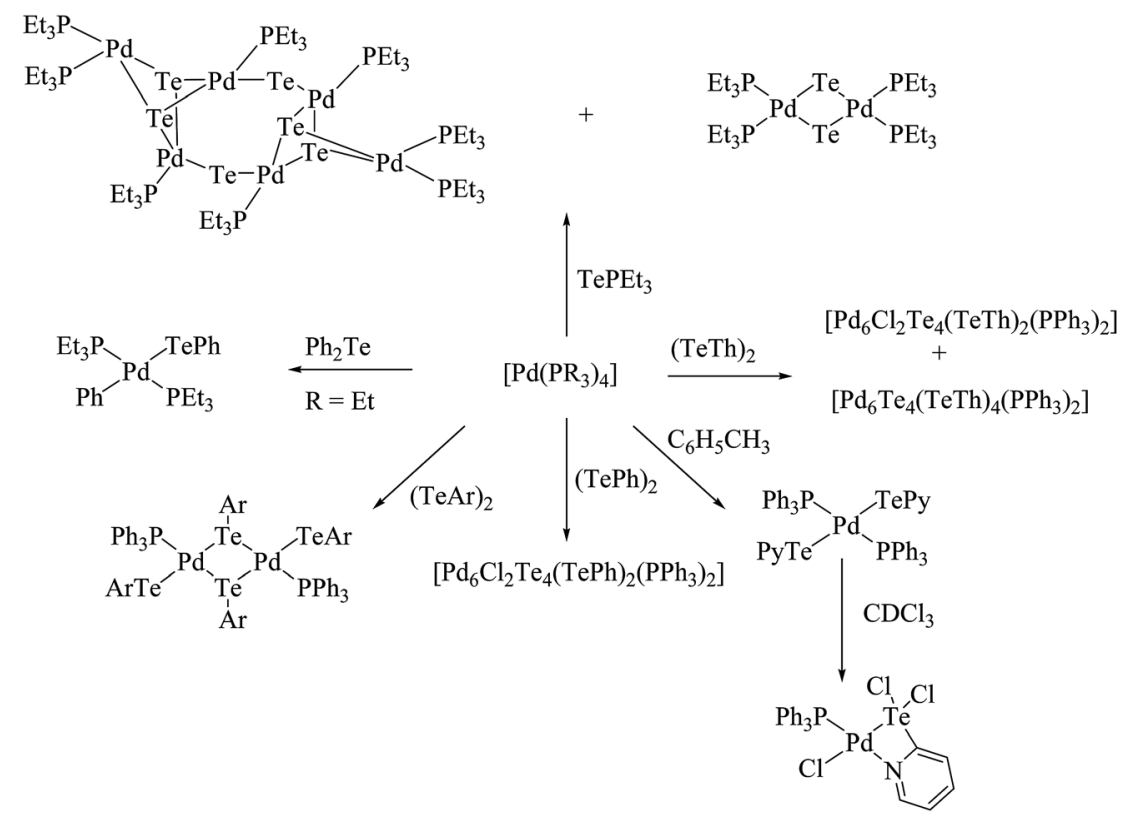

Scheme 14 Oxidative addition of $\left[\mathrm{Pd}\left(\mathrm{PR}_{3}\right)_{4}\right](\mathrm{R}=\mathrm{Et}, \mathrm{Ph})$ with various diorganoditellurides. 


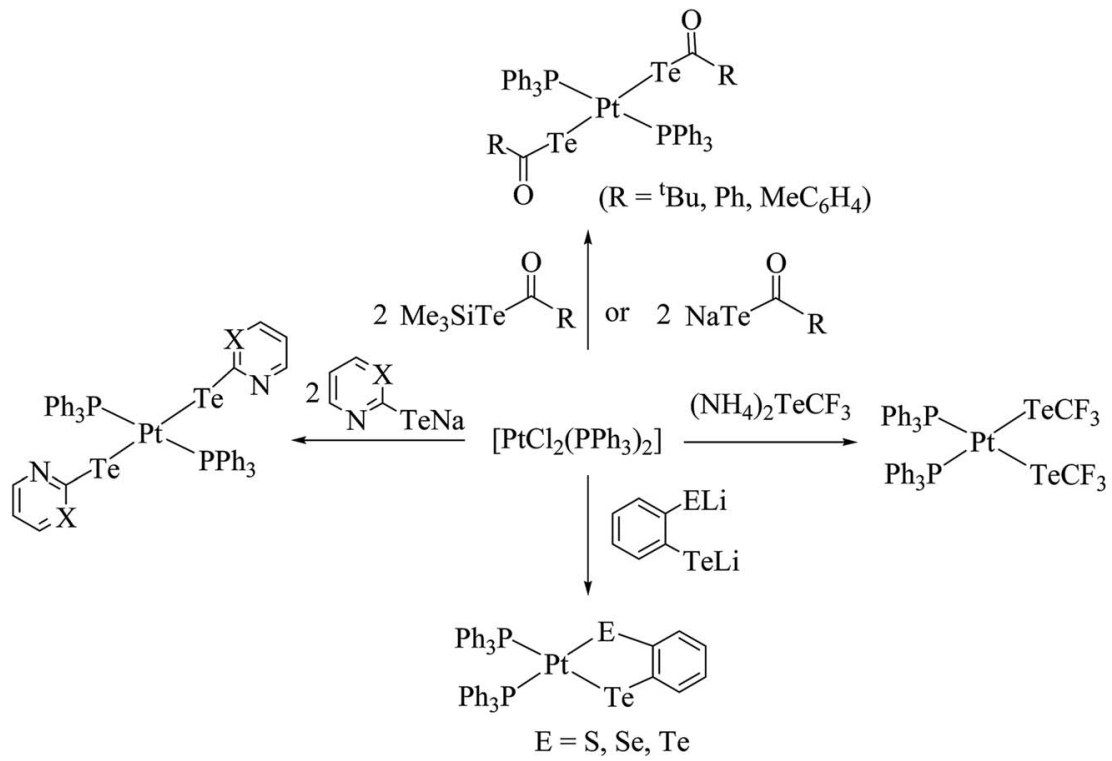

Scheme 15 Reactions of $\left[\mathrm{PtCl}_{2}\left(\mathrm{PPh}_{3}\right)_{2}\right]$ with various sodium/lithium salts of aryl tellurolates.

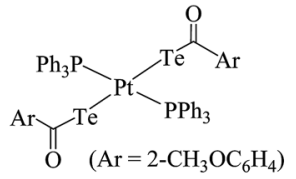

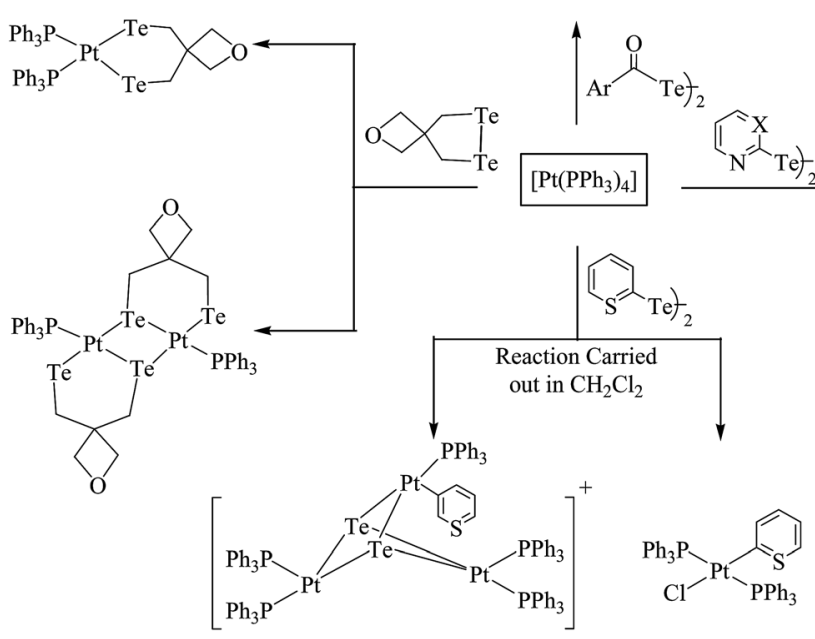

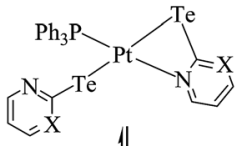

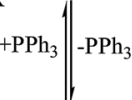

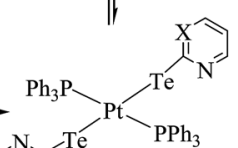<smiles></smiles><smiles>[X]C(C)(C)C</smiles>
Recrystallization

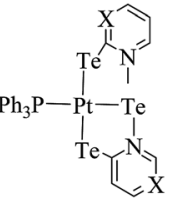
$(\mathrm{X}=\mathrm{CH}, \mathrm{CMe}, \mathrm{N})$

Scheme 16 Oxidative addition reactions of $\left[\mathrm{Pt}\left(\mathrm{PPh}_{3}\right)_{4}\right]$ with various diaryl ditellurides.

(Fig. 11). The serendipitous isolation of the latter one was also justified by the substitution reaction of $\left[\mathrm{PtCl}_{2}\left(\mathrm{PPh}_{3}\right)_{2}\right]$ with the $2 \mathrm{NaTeC}_{5} \mathrm{H}_{3}(3-\mathrm{R}) \mathrm{N}(\mathrm{R}=\mathrm{H}, \mathrm{Me})$ (Scheme 15). The crystal structure of $\left[\mathrm{Pt}\left\{\mathrm{TeC}_{5} \mathrm{H}_{3}(3-\mathrm{R}) \mathrm{N}\right\}_{2} \mathrm{Te}\left(\mathrm{PPh}_{3}\right)\right]$ showed that the bare tellurium was directly coordinated to the metal center and flanked by the two pyridyl rings (Fig. 5). Density function calculations highlighted that the extra stability of this complex was due to the aromatic nature of the five-membered ring formed by $\mathrm{Pt}-\mathrm{Te}-\mathrm{C}-\mathrm{N}-\mathrm{Te}$. While similar reactions in the case of palladium led to isolation of an expected oxidative addition product, ${ }^{8}$ which on keeping for a longer time period in $\mathrm{CDCl}_{3}$ solution, yielded a green product, $\left[\mathrm{PdCl}\left\{\mathrm{Te}(\mathrm{Cl})_{2} \mathrm{C}_{5} \mathrm{H}_{4} \mathrm{~N}\right\}\left(\mathrm{PPh}_{3}\right)\right]$, in which tellurium is oxidized from $\mathrm{a}+2$ to $\mathrm{a}+4$ oxidation state by the attachment of two chlorine atoms (Scheme 7).

A new class of platinum(0) phosphine precursors $\left[\mathrm{Pt}\left(\eta^{2}-\right.\right.$ norborene) $\left.\left(\mathrm{PPh}_{3}\right)_{2}\right]$ has also been applied to study oxidative addition with bulky ditellurides of dibenzobarrelenyl and norborene. The reaction afforded the formation of four- and fivemembered telluraplatinacycles compounds $\left[\mathrm{Pt}(\mathrm{Te} \cap \mathrm{C})\left(\mathrm{PPh}_{3}\right)_{3}\right]$ in the presence of excess triphenyl phosphine. ${ }^{139}$

4.3.2. Reactivity of various tellurolates with palladium and platinum chelated phosphine precursors. The reactivity of the 


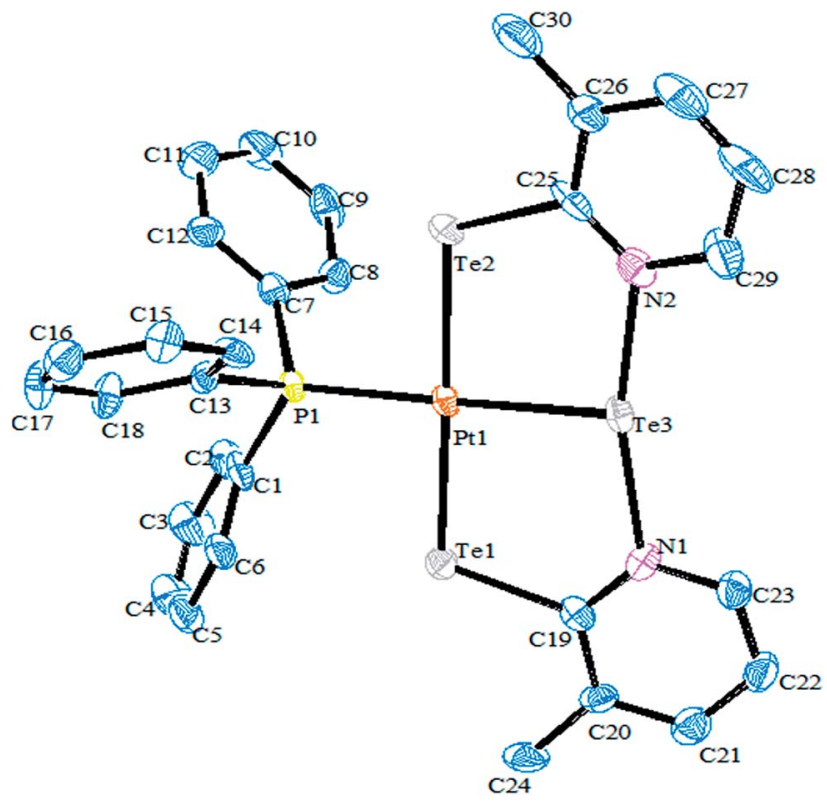

Fig. 11 Crystal structure of $\left[\mathrm{Pt}\left\{\mathrm{TeC}_{5} \mathrm{H}_{3}(3-\mathrm{Me}) \mathrm{N}\right\}_{2} \mathrm{Te}\left(\mathrm{PPh}_{3}\right)\right]$ (redrawn from ref. 7).

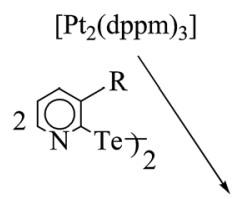

$\left[\mathrm{PtCl}_{2}(\mathrm{dppm})\right]$

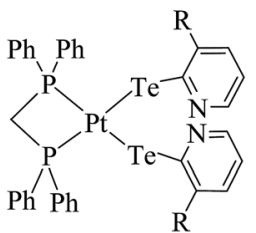

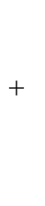<smiles></smiles>

$\mathrm{Ph} \mathrm{Ph} \mathrm{Ph} \mathrm{Ph}$

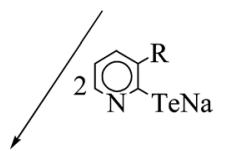

Scheme 17 Reactions of $\left[\mathrm{Pt}_{2}(\mathrm{dppm})_{3}\right] /\left[\mathrm{PtCl}_{2}(\mathrm{dppm})\right]$ with dipyridyl ditellurides/pyridyl tellurolates, respectively.

chelating phosphine diphenylphosphinomethane (dppm) ligand is comparatively higher than that of other chelating phosphines. The main striking factor of the reactivity is strain, caused by the projection of the four-membered ring. The cone angle drawn on $\mathrm{P}-\mathrm{M}-\mathrm{P}$ ranges from $70-72^{\circ}$, which means it is highly acute. To overcome the acuteness, the complementary angle is widened in space to provide the space to react with the incoming ligand. In the case of the substitution reaction between $\left[\mathrm{PtCl}_{2}(\mathrm{dppm})\right]$ and the sodium salt of aryl tellurolates (aryl $=\mathrm{Ph}$, Tol, Mes), cis configured mononuclear complexes were obtained. ${ }^{\mathbf{1 3 3 , 1 4 0 , 1 4 1}}$ However, a similar substitution and an oxidative addition with hemilabile ligand systems, like derivatives of 2 and 4-dipyridylditelluride, yielded an expected mononuclear complex as well as $\mathrm{C}-\mathrm{H}$ activated $\left[\mathrm{Pt}\left\{\mathrm{Ph}_{2}-\right.\right.$ $\left.\left.\mathrm{PCH}\left(\mathrm{TeC}_{5} \mathrm{H}_{3}(3-\mathrm{R}) \mathrm{NPPh}_{2}\right\}_{2}\right)\right](\mathrm{R}=\mathrm{H}, \mathrm{Me})$ (Scheme 17). ${ }^{\mathbf{8}, 131}$ The latter complexes had a distorted square planer geometry around the metal, with the angle around the activated carbon center varying from $100-126^{\circ}$, which shows an allylic configuration of

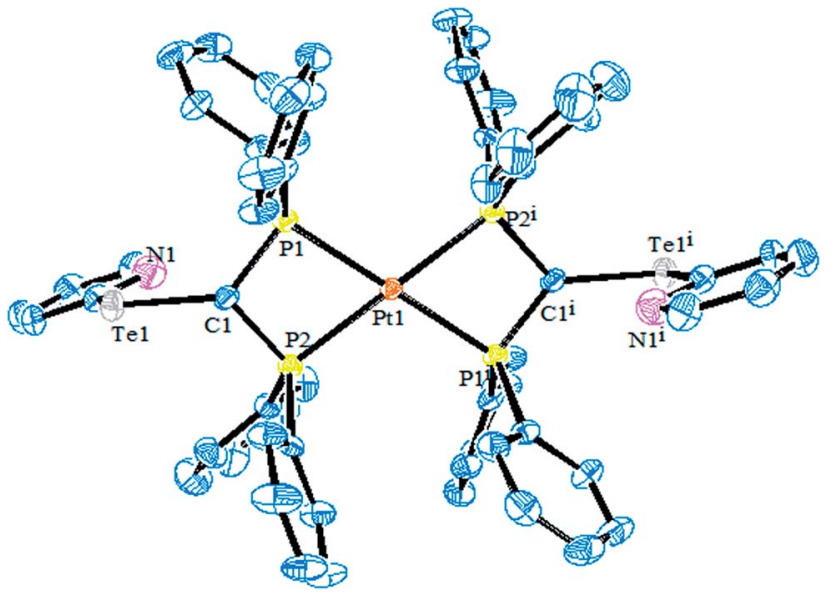

Fig. 12 Crystal structure of $\left[\mathrm{Pt}\left\{\mathrm{PPh}_{2} \mathrm{CH}\left(\mathrm{TeC}_{5} \mathrm{H}_{4} \mathrm{~N}\right) \mathrm{PPh}_{2}\right\}_{2}\right]$ (redrawn from ref. 8).

the carbon center (Fig. 12). It can be concluded that the reactivity of the same palladium phosphine precursors with 4-pyridyl tellurolates to lead to the tetranuclear compound $\left[\operatorname{Pd}_{2}(\mu-\right.$ $\left.\mathrm{Te})\left(\mu_{2}-\mathrm{TeC}_{5} \mathrm{H}_{4} \mathrm{~N}\right)\left(4-\mathrm{TeC}_{5} \mathrm{H}_{4} \mathrm{~N}\right)(\mu-\mathrm{dppm})\right]_{2}$ (ref. 131) can be rationalized by the high reactivity of the palladium phosphine precursor and tellurium-based ligand.

However, the chemistry related to diphenylphosphinoethane with tellurium systems seemed to be as expected. This may be due to the strainless five-membered ring project by "dppe" ligand. On performing an oxidative addition/substitution reaction between $\left[\mathrm{Pt}(\mathrm{dppe})_{2}\right] /\left[\mathrm{PtCl}_{2}\right.$ (dppe)] and the aryl ditellurides/ sodium salt of aryl tellurolate (aryl = py, Ph, tol, Mes, Thienyl), a mononuclear product was isolated..$^{\mathbf{8 , 1 4 0 , 1 4 1}}$ Only in the case of the methyl-substituted telluropyridne ligand system was a complex with the composition $\left[\mathrm{PtCl}\left\{\mathrm{TeC}_{5} \mathrm{H}_{3}(3-\mathrm{Me}) \mathrm{N}\right\}(\mathrm{dppe})\right]$ isolated, which existed in equilibrium with the moiety $\left[\mathrm{Pt}\left\{\kappa^{2}-\right.\right.$

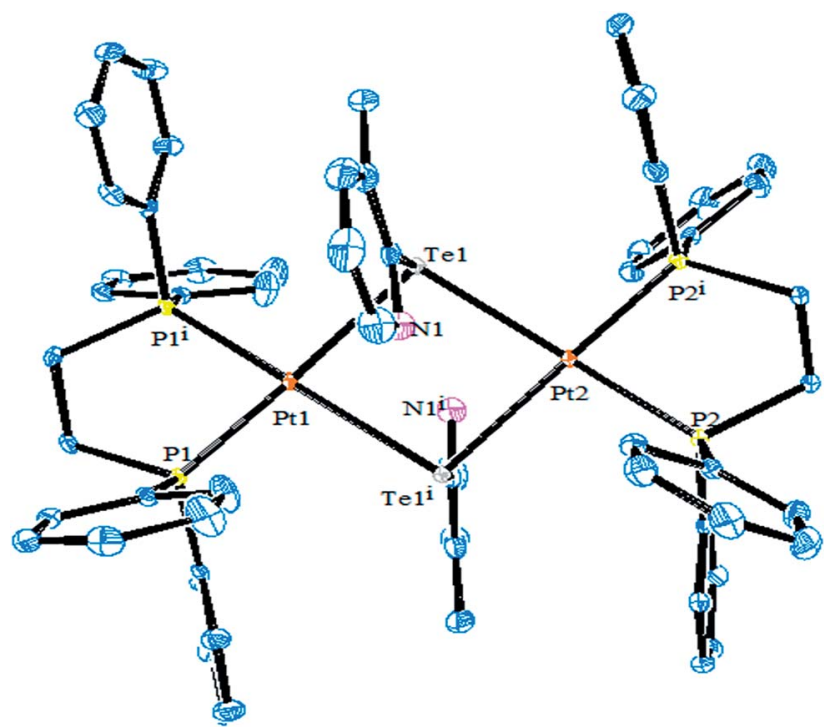

Fig. 13 Crystal structure of $\left[\mathrm{Pd}_{2}\left\{\mu T e C_{5} \mathrm{H}_{3}(3-\mathrm{Me}) \mathrm{N}\right\}_{2}\right.$ (dppe)] (redrawn from ref. 8). 
<smiles>[Z10]c1[X]c([R20]([H])([H])[H])cc([R])n1</smiles><smiles>[R]c1cc(C(C)C(C)C)c([Y])nc1[Y9]</smiles>

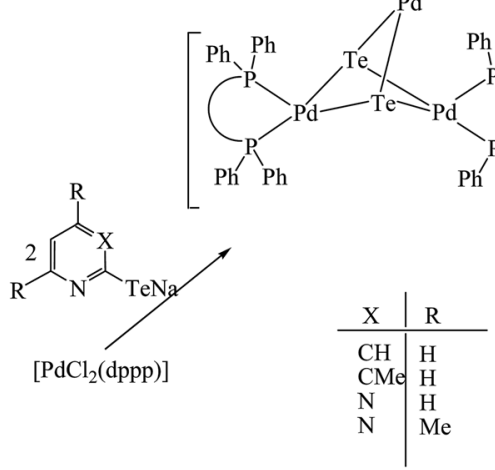
$\mathrm{Cl}_{2}$

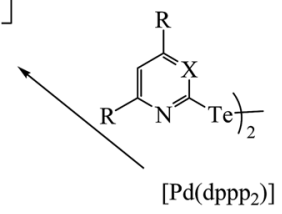

Scheme 18 Reactions of $\left[\mathrm{Pd}(\mathrm{P} \cap \mathrm{P})_{2}\right]$ and $\left[\mathrm{PdCl}_{2}(\mathrm{P} \cap \mathrm{P})\right](\mathrm{P} \cap \mathrm{P}=\mathrm{dppe}$, dppp) with $\mathrm{Ar}_{2} \mathrm{Te}_{2}\left(\mathrm{Ar}=\left\{\mathrm{C}_{5} \mathrm{H}_{3}(3-\mathrm{R}) \mathrm{N}\right\},\left\{\mathrm{C}_{5} \mathrm{H}_{2}(4,6-\mathrm{R}) \mathrm{N}\right\}(\mathrm{R}=\mathrm{H}, \mathrm{Me})\right)$ and their corresponding sodium salts.

$\left.\left.\mathrm{TeC}_{5} \mathrm{H}_{3}(3-\mathrm{Me}) \mathrm{N}\right\}(\mathrm{dppe})\right]^{+}$. Conductometric measurements were performed to correlate the nature of the complex in solution and it was reported that in the case of highly polar solvents, like methanol and acetonitrile, the nature of the complex was a $1: 1$ electrolyte. Surprisingly, the palladium chemistry is totally different from their platinum analogs. On performing a similar reaction between palladium phosphine precursors $\left[\mathrm{Pd}(\mathrm{dppe})_{2}\right] /$ $\left[\mathrm{PdCl}_{2}(\mathrm{dppe})\right]$ with hemilabile ligand systems, like pyridyl (Fig. 13) and pyrimidyl ditelluride,,$^{\mathbf{8 , 4 8 , 1 4 1}}$ resulted the rapid conversion of mono- to trinuclear complex in a chlorinated solvent (Scheme 18). This result shows the high susceptibility of tellurium ligands toward the chlorinated solvents.

In the case of platinum precursors of diphenylphosphinopropane (dppp), like $\left[\mathrm{Pt}(\mathrm{dppp})_{2}\right] /\left[\mathrm{PtCl}_{2}(\mathrm{dppp})\right]$, performing a similar reaction as mentioned above with various hemilabile ligand systems afforded mono- and trinuclear products. ${ }^{\mathbf{8 , 4 8}}$ However, the reaction with palladium phosphine precursors yielded only trinuclear products in a moderately good yield. A mechanistic study was performed to isolate the trinuclear product by the mild reaction between $\left[\mathrm{PdCl}_{2}(\mathrm{dppp})\right]$ and $\left[\mathrm{Pb}\left(\mathrm{TeC}_{5} \mathrm{H}_{4} \mathrm{~N}\right)_{2}\right]$ (Scheme 19). ${ }^{8}$ Upon recording the ${ }^{31} \mathrm{P}\left\{{ }^{1} \mathrm{H}\right\}$ NMR within $2 \mathrm{~h}$ stirring of the reaction, there was a single resonance corresponding to mononuclear complexes, which again on further stirring for up to $4-5 \mathrm{~h}$ at the same temperature showed two quite shielded resonances, corresponding to bi- and trinuclear products. By the extraction of the product in dichloromethane, the trinuclear product was exclusively isolated. The formation of bi- and trinuclear products was also characterized with single crystal X-ray analysis.

Weigand et al. had applied a new class of $\mathrm{Pt}(0)$ precursors $[\mathrm{Pt}(\mathrm{dppn})(\mathrm{nb})]$ derived from the chelating phosphine

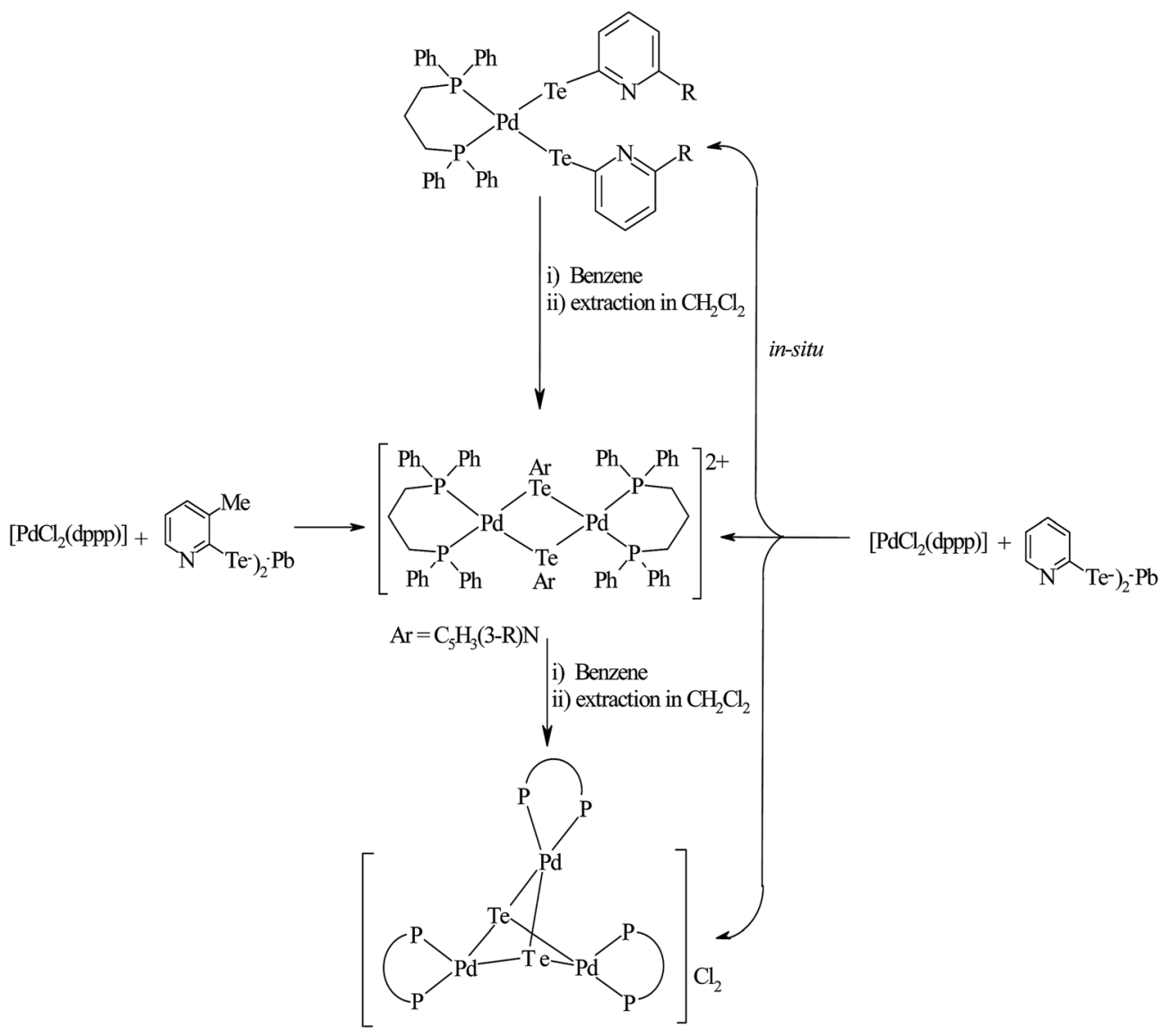

Scheme 19 Reactions of $\left[\mathrm{PdCl}_{2}(\mathrm{dppp})\right]$ with the lead salts of 2-pyridine chalcogenolate. 

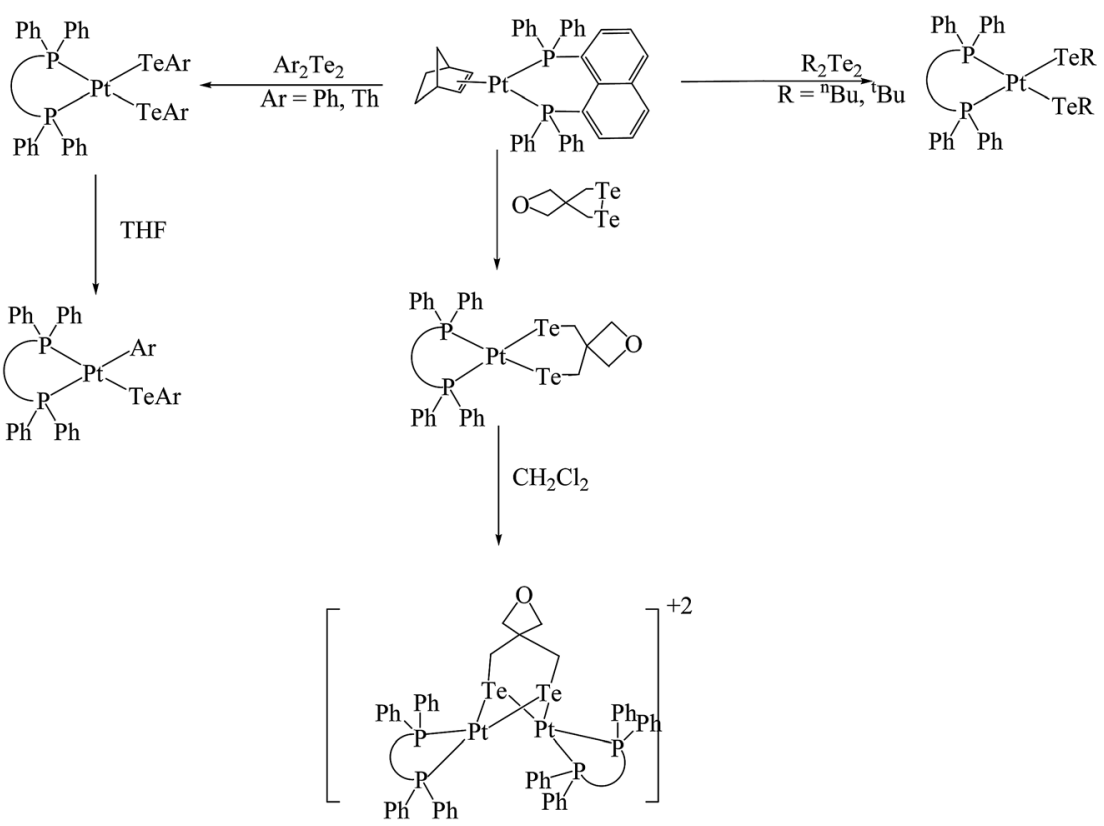

Scheme 20 Oxidative addition reaction between $[\mathrm{Pt}(\mathrm{dppn})(\mathrm{nb})]$ with various cyclic and acyclic diorgano ditellurides.<smiles>[X][Te]C([X])=C</smiles><smiles>[Y4]C(=C)C([3H])[Te]</smiles><smiles>[X]C(=C)[I+]([M])[X]</smiles><smiles>[Y1][Te]C(=C)[X]([Y1])C=C</smiles><smiles>[Y][X]C(=C)C([Te])[Te]</smiles>

$(\mathrm{X}=\mathrm{N}, \mathrm{O}, \mathrm{S})$

Scheme 21 Various coordination modes in hemilabile tellurolate ligand systems.

diphenylphosphineno naphthalene $\left(\mathrm{Ph}_{2} \mathrm{P}\right.$-napthyl- $\left.\mathrm{PPh}_{2}\right){ }^{136}$ These precursors showed a remarkable reactivity toward ditelluride systems. Upon reaction with various cyclic/saturated, acyclic/saturated, and cyclic/unsaturated ditellurides, the momonuclear $\left[\mathrm{Pt}\left(\mathrm{Te}_{2} \mathrm{C}_{5} \mathrm{H}_{8} \mathrm{O}\right)(\mathrm{dppn})\right]$ and binuclear $\left[\mathrm{Pt}\left(\mathrm{Te}_{2} \mathrm{C}_{5^{-}}\right.\right.$ $\left.\mathrm{H}_{8} \mathrm{O}\right)($ dppn)] products were isolated, which on keeping for a prolonged time period in the solvent decomposed into several products (Scheme 20). It was noticed that alkyl tellurides result in the products by the cleavage of Te-Te bonds, however aryl telluride derives the products not only by the Te-Te bond cleavage but also by Te-C bond cleavage. ${ }^{136}$

Notable attention ${ }^{7,8}$ has been drawn by the outcome of the above-mentioned document conclusion on hemilabile ligands. The discussion focused on complexes derived by hemilabile organochalcogens, which have been the subject of considerable interest due to their rich coordination chemistry. In fact, as a concluding remark, the coordination potential of hemilabile ligand systems, especially those that possess $\alpha$ heteroatoms as well as their corresponding anions, referred to as chalcogenolates, is immense. ${ }^{\mathbf{1 , 9 , 1 0}}$ There is indeed a considerable versatility in the various coordination modes of these molecules, which may include monodentate binding through $\mathrm{E}$ or through heteroatoms, bridging through a single $\mathrm{E}$, bridging through both $\mathrm{E}$ and $\mathrm{N}$, or chelating via the $\mathrm{E}$ to $\mathrm{N}$ backbone. ${ }^{\mathbf{4 8 , 1 3 4}}$ All these coordination modes, either alone or in combination, have been observed or assigned on the basis of spectroscopic and/or crystallographic evidence of both homo- and heteroleptic metal complexes (Scheme 21).

\section{Metal tellurides}

The binuclear complexes $\left[\mathrm{M}_{2}(\mu-\mathrm{Te})_{2}(\mathrm{dppe})_{2}\right](\mathrm{M}=\mathrm{Pd}, \mathrm{Pt})$ (Fig. 14) act as a powerful metallophilic ligand to provide a binding site for various transition metals, $\mathrm{d}^{10}$ systems, and lanthanide metal centers. The former complexes can be isolated by the reaction between $\mathrm{M}^{2+}$, dppe, and $\mathrm{NaTeH}$ in a $\mathrm{N}, \mathrm{N}$-dimethylformamide and acetonitrile mixture. ${ }^{142}$ The reaction of $\left[\mathrm{Pt}\left(\mathrm{CH}_{3} \mathrm{CN}\right)_{4}\left(\mathrm{NO}_{3}\right)_{2}\right]$ with a similar composition to the former complexes led to the formation of pentanuclear complexes [Pt $\left.\left\{\mathrm{Pd}_{2}(\mu-\mathrm{Te})_{2}(\mathrm{dppe})_{2}\right\}_{2}\right]^{2+}$ (ref. 142) (Fig. 15) in which the platinum metal center was coordinated with all four bridging tellurido linkages. Similarly, various trinuclear products have been isolated by the reaction between $\mathrm{M}^{2+}, \mathrm{P} \cap \mathrm{P}$, and $\mathrm{NaTeH}$ in $N, N$ dimethylformamide for more than $20 \mathrm{~h}$ stirring (Scheme 22). ${ }^{\mathbf{1 4 3}}$ Undoubtedly, strong coordinating solvents, like DMF, $\mathrm{CH}_{3} \mathrm{CN}$, may enable the coordination of tellurium to further platinum moieties with ease, resulting in tri- to pentanuclear products. ${ }^{143-146}$ Morley et al. also isolated the trinuclear product $\left[\mathrm{Pt}_{3}\left\{(\mu-\mathrm{Te})_{2}(\mathrm{dppe})_{2}\right\}_{2}\right]^{2+}$ by the oxidative addition of [Pt(dppe $\left.)_{2}\right]$ and vitreous tellurium under refluxing for $5 \mathrm{~h} .{ }^{\mathbf{1 4 7}}$ The isolation 


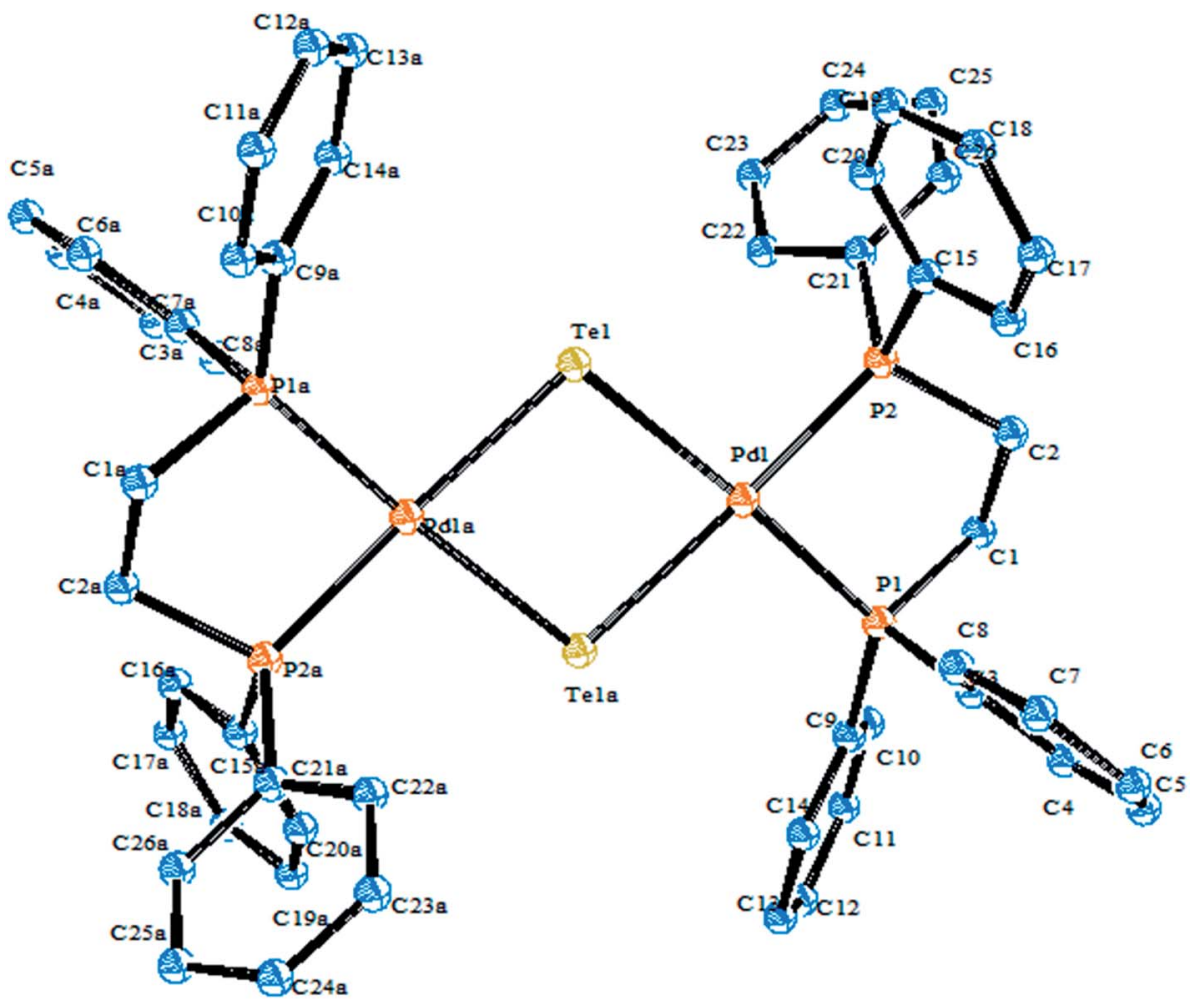

Fig. 14 Crystal structure of $\left[\operatorname{Pd}_{2}(\mu-T e)_{2}(d p p e)_{2}\right]^{2+}$ (redrawn from ref. 142).

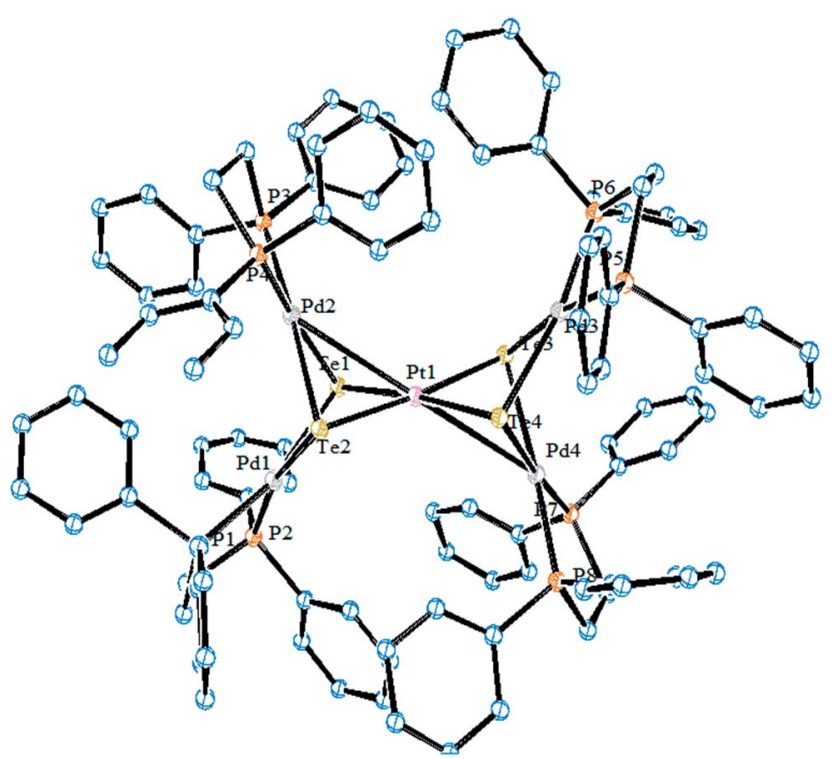

Fig. 15 Crystal structure of $\left[\operatorname{Pt}\left\{\mathrm{Pd}_{2}(\mu-\mathrm{Te})_{2}(\mathrm{dppe})_{2}\right\}_{2}\right]^{2+}$ (redrawn from ref. 142).

of the trinuclear product via an oxidative addition mode is unprecedented and could be rationalized by the fact that the higher nucleophilicity of tellurium makes it highly susceptible to the nucleophilic attack of chlorinated solvents.

Redox studies of these complexes were studied by cyclic voltammetry. ${ }^{142,144,145}$ In the case of telluride bridged cluster complexes, it all depends upon the nature of the phosphine and metal center. The cyclic voltammograms of dppe-derived complexes showed a reversible nature, whereas it was irreversible in other cases. The order of chemical reversibility followed the trend: dppe $>$ dppp $>$ dppm.

Cluster compounds like $\left[\mathrm{PPh}_{4}\right]_{2}\left[\mathrm{Pd}\left(\mathrm{Te}_{4}\right)_{2}\right]$ were synthesized by refluxing the palladium precursor with tellurium powder. ${ }^{148}$ This intriguing complex exists in two crystallographic forms: the $\alpha$ and $\beta$ forms. The triclinic $\alpha$ and orthorhombic $\beta$ forms were separated using ethylene diamine and ether solvents, respectively. ${ }^{148-150}$ Similarly, the complex $\left[\mathrm{Li}_{4}(\mathrm{en})_{10}\right]\left[\mathrm{Pd}_{6}\left(\mu_{3}-\mathrm{Te}\right)_{8}\right]$ was formed by the reaction of $\left[\mathrm{Pb}_{2} \mathrm{Te}_{3}\right]^{2-}$ with $\left[\mathrm{PdCl}_{2}\left(\mathrm{PPh}_{3}\right)_{2}\right] .{ }^{151}$ Contrary to the palladium precursors, the platinum analog resulted in the cluster complex $\left[\mathrm{Pt}_{4} \mathrm{Te}_{4}\left(\mathrm{Te}_{3}\right)_{6}\right]^{4-}$, which was comprised of a $\mathrm{Pt}_{4} \mathrm{Te}_{4}$ cubane core with a distorted octahedral configuration around the platinum atom. ${ }^{152}$ Recently, several platinum group cluster complexes were isolated by refluxing $\mathrm{TeCl}_{4}$ with the corresponding metal precursors. ${ }^{153-156}$ The high nucleophilicity of the terminal telluride in mononuclear complexes makes them highly susceptible for further reaction with coordinative unsaturated complexes like the $\mathrm{Pt}(0)$ and $\operatorname{Pd}(0)$ precursors. Thus, when the oxidative addition product $\left[\mathrm{CpIr}(\mathrm{CO})(\mathrm{TeTol})_{2}\right]$ was subjected to reaction with two equivalent of $\left[\mathrm{M}\left(\mathrm{PPh}_{3}\right)_{4}\right](\mathrm{M}=\mathrm{Pd}, \mathrm{Pt})$ (Scheme 23), a compound of the type $\left[\mathrm{CpIr}(\mathrm{CO})\left(\mu_{3}-\mathrm{Te}\right)_{2}\left\{\mathrm{MTol}\left(\mathrm{PPh}_{3}\right)\right\}_{2}\right]$ was isolated, while the similar reaction with one equivalent of $\left[\mathrm{Pt}\left(\mathrm{PPh}_{3}\right)_{4}\right]$ yielded the intermediate product $\left[\mathrm{CpIr}(\mathrm{CO})(\mu-\mathrm{Te})(\mu\right.$-TeTol $\left.)\left\{\mathrm{PtTol}\left(\mathrm{PPh}_{3}\right)\right\}\right] .{ }^{157}$ The latter complexes upon reaction with $\left[\mathrm{Pd}\left(\mathrm{PPh}_{3}\right)_{4}\right]$ derived the heterometallic complex $\quad\left[\mathrm{CpIr}(\mathrm{CO})(\mu-\mathrm{Te})_{2}\left\{\operatorname{PdTol}\left(\mathrm{PPh}_{3}\right)\right\}\right.$ 


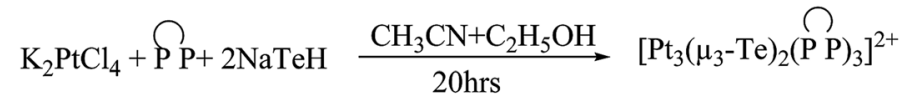

$$
\begin{aligned}
& {\left[\mathrm{Pd}\left(\mathrm{NO}_{3}\right)_{2}\right]+\bigcap_{\mathrm{P}+2 \mathrm{NaTeH}} \underset{20 \mathrm{hrs}}{\mathrm{CH}_{3} \mathrm{CN}+\mathrm{C}_{2} \mathrm{H}_{5} \mathrm{OH}}\left[\mathrm{Pt}_{3}\left(\mu_{3}-\mathrm{Te}\right)_{2}(\mathrm{P} \mathrm{P})_{3}\right]^{2+}}
\end{aligned}
$$

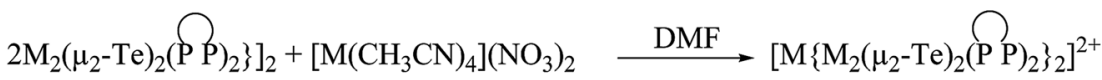

$$
\begin{aligned}
& (\mathrm{M}=\mathrm{Pd}, \mathrm{Pt})\left(\mathrm{P}^{\cap} \mathrm{P}=\right.\text { dppe, dppp, dppb) }
\end{aligned}
$$

Scheme 22 Various approached used for the synthesis of high nuclearity complexes.

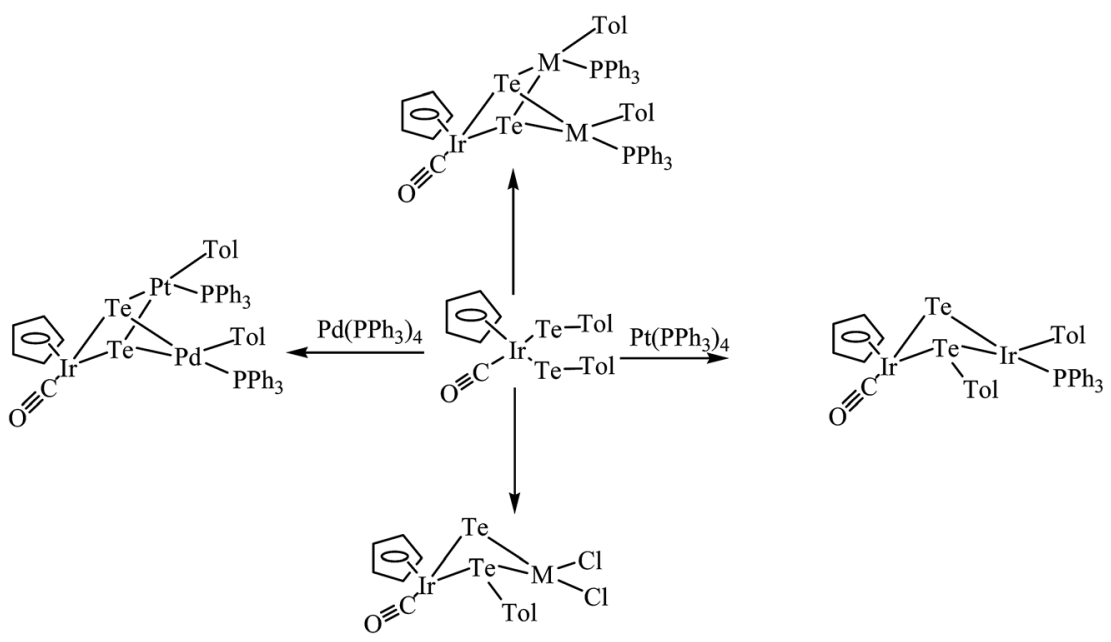

Scheme 23 Synthesis of various heterometallic complexes bridged with telluride systems.

$\left\{\right.$ PtTol $\left.\left.\left(\mathrm{PPh}_{3}\right)\right\}\right]$ (Fig. 16), which was formed by the facile inversion of the $\operatorname{Pd}(0)$ center in to a Te-Tol bond in the complex $\left[\mathrm{CpIr}(\mathrm{CO})(\mu-\mathrm{Te})(\mu-\mathrm{TeTol})\left\{\operatorname{PtTol}\left(\mathrm{PPh}_{3}\right)\right\}\right] .^{126,157}$

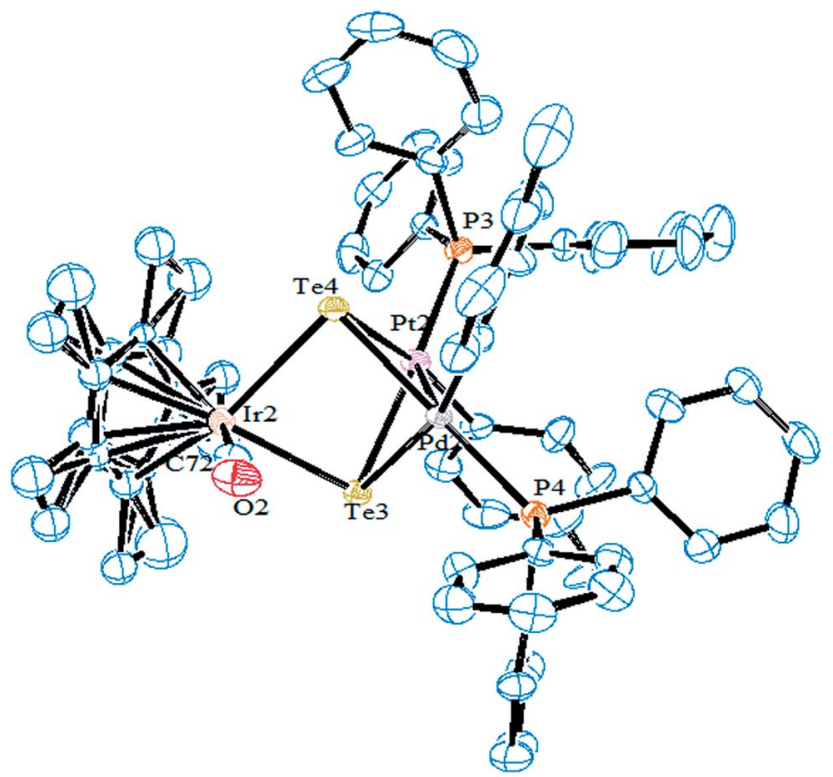

Fig. 16 Crystal structure of $\left[\mathrm{Cplr}(\mathrm{CO})(\mu-\mathrm{Te})_{2}\left\{\mathrm{PdTol}_{(\mathrm{PPh}}\right)\right\}$ $\left.\left\{\mathrm{PtTol}\left(\mathrm{PPh}_{3}\right)\right\}\right]$ (redrawn from ref. 157).
Similarly, $\left[\mathrm{Pt}(\mathrm{TeR})_{2}(\mathrm{dppe})\right](\mathrm{R}=\mathrm{Ph}, \mathrm{Fc})$ upon reaction with a rhenium carbonyl cluster yielded heterometallic tellurolato bridged complexes $\left[(\mathrm{dppe}) \mathrm{Pt}(\mu-\mathrm{TeR})_{2} \operatorname{ReCl}(\mathrm{CO})_{3}\right](\mathrm{R}=\mathrm{Ph}, \mathrm{Fc}) .{ }^{\mathbf{1 5 8 , 1 5 9}}$

\section{Applications}

\subsection{Catalysis}

The efficient and selective transformation of various functional groups have taken place with sodium hydrogen telluride (NaHTe) and $\mathrm{Na}_{2} \mathrm{Te}$, which have been reported in further applications in recent years. ${ }^{\mathbf{1 6 0 - 1 6 4}}$ In particular, the reduction of aromatic aldehydes to alcohols is the most important transformation by $\mathrm{Na}_{2} \mathrm{Te}$ in NMP ( $N$-methyl-2-pyrorolidone). ${ }^{165,166}$ Similarly, an attempted reduction of aromatic nitriles serendipitously led to the pharmacologically important product 7diaza-9H purines in low yields (Scheme 24). ${ }^{\mathbf{1 6 6 - 1 6 8}}$

One more striking example of the conversion by debromination of vic-dibromides to alkenes is that catalyzed by $p$ methoxyphenyltelluride. Again on reinvestigation, it was found that the more electron-rich diorganoditellurides associated with reducing agents, like glutathione (GSH) or sodium ascorbate, are better debrominating agents than the previous reaction (Scheme 24). ${ }^{169-171}$

Recently, it was found that ruthenium complexes derived by various telluroethers, like $\left[\left(\eta^{6}-\mathrm{C}_{6} \mathrm{H}_{6}\right) \mathrm{Ru}(\mathrm{L})\right]\left(\mathrm{PF}_{6}\right) \quad(\mathrm{L}=2$ - 

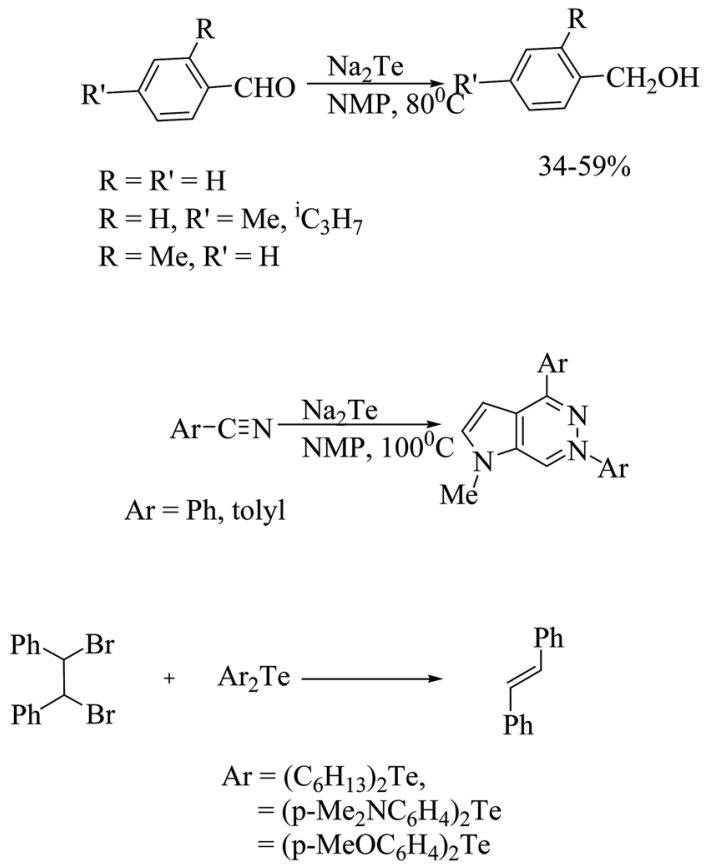

Scheme 24 Schematic representation of various reactions catalyzed by organotellurium analogs.

$$
\overbrace{\mathrm{R}^{\prime}}^{\mathrm{OH}} \stackrel{\left[\left(\mathrm{n}^{6}-\mathrm{C}_{6} \mathrm{H}_{6}\right) \mathrm{Ru}(\mathrm{L})^{2+}\right]}{\text { Oxidising agent }} \underset{\substack{\left.\left.\mathrm{L}=2-\mathrm{MeSC}_{6} \mathrm{H}_{4} \mathrm{CH}=\mathrm{NCH}_{2}\right)_{2} \mathrm{Te} \\ 2 \mathrm{MeSC}_{6} \mathrm{H}_{4} \mathrm{CH}_{2} \mathrm{NH}_{2} \mathrm{CH}_{2}\right)_{2} \mathrm{Te}}}{\stackrel{2}{\longrightarrow}}
$$

Scheme 25 Oxidation of alcohols through ruthenium tellurolate complexes.

$\mathrm{MeSC}_{6} \mathrm{H}_{4} \mathrm{CH}=\mathrm{NCH}_{2} \mathrm{CH}_{2} \mathrm{EC}_{6} \mathrm{H}_{4}-\mathrm{R} ; \mathrm{R}=\mathrm{H}, \mathrm{E}=\mathrm{S}$, Se; 2-MeSC ${ }_{6}^{-}$ $\left.\mathrm{H}_{4} \mathrm{CH}_{2} \mathrm{NHCH}_{2} \mathrm{CH}_{2} \mathrm{EC}_{6} \mathrm{H}_{4}-\mathrm{R} ; \mathrm{R}=\mathrm{OMe}, \mathrm{E}=\mathrm{Te}\right),{ }^{63}$ have proven potential as an excellent catalyst in the oxidation of primary and secondary alcohols. The TON values for the oxidation of various alcohols, like cyclic, acyclic, and benzylic, ranged from 7.8-9.6 $\times 10^{4}$. Strikingly, the complex $\left(\eta^{6}-\mathrm{C}_{6} \mathrm{H}_{6}\right)\left[\mathrm{Ru}\left(2-\mathrm{MeSC}_{6} \mathrm{H}_{4} \mathrm{CH}_{2}\right.\right.$ $\left.\left.\mathrm{NHCH}_{2} \mathrm{CH}_{2} \mathrm{TeC}_{6} \mathrm{H}_{4}-\mathrm{OMe}\right)\right]\left(\mathrm{PF}_{6}\right)$ appeared to be the most efficient in this process with the highest \% conversion (98\%). A comparative study of all the ruthenium complexes derived by various chalcogen analogs showed that the catalytic efficiency varies in the order of $\mathrm{Te}>\mathrm{Se}>\mathrm{S}$. This fact can be rationalized by the softer ligand making it easier to form the intermediate oxy species $\mathrm{Ru}=\mathrm{O}$, which plays a pivotal role in any oxidation reaction (Scheme 25).

The second important class of reaction, i.e., transfer of hydrogen reaction, is also catalyzed by the complexes $\left[\left(\eta^{6}-\mathrm{C}_{6} \mathrm{H}_{6}\right)\right.$

$$
\begin{aligned}
& \stackrel{\mathrm{R}}{\mathrm{O}}_{\mathrm{R}^{\prime}}^{\mathrm{O}} \frac{\left[\left(\mathrm{n}^{6}-\mathrm{C}_{6} \mathrm{H}_{6}\right) \mathrm{Ru}(\mathrm{L})^{2+}\right]}{2-\text { propanol, } \mathrm{KOH}} \mathrm{R}_{\mathrm{R}^{\prime}}^{\mathrm{OH}} \\
& \left.\mathrm{L}=2-\mathrm{MeSC}_{6} \mathrm{H}_{4} \mathrm{CH}=\mathrm{NCH}_{2}\right)_{2} \mathrm{Te}
\end{aligned}
$$

Scheme 26 Transfer of hydrogen reaction catalyzed by ruthenium tellurolate complexes.
$\mathrm{Ru}(\mathrm{L})]\left(\mathrm{PF}_{6}\right)\left(\mathrm{L}=2-\mathrm{MeSC}_{6} \mathrm{H}_{4} \mathrm{CH}=\mathrm{NCH}_{2} \mathrm{CH}_{2} \mathrm{EC}_{6} \mathrm{H}_{4}-\mathrm{R} ; \mathrm{R}=\mathrm{H}, \mathrm{E}=\right.$ $\mathrm{S}$, Se; 2- $\mathrm{MeSC}_{6} \mathrm{H}_{4} \mathrm{CH}_{2} \mathrm{NHCH}_{2} \mathrm{CH}_{2} \mathrm{EC}_{6} \mathrm{H}_{4}-\mathrm{R} ; \mathrm{R}=\mathrm{OMe}, \mathrm{E}=\mathrm{Te}$ ) (Scheme 26). In the case of acetophenone, the conversion efficiency was up to $98 \%$, while in various other aliphatic secondary ketones, it ranged up to $90 \%$. Similarly as an oxidation reaction, the catalytic efficiency of these reactions also varies in the same order. An earlier well-established catalyst for this reaction was $\mathrm{Ru}(\mathrm{II})$ complexes of 2-(aminomethyl)pyridine phosphine with a TOF of $10^{-5} \mathrm{~h}^{-1}$ and up to $97 \%$ conversion in 2-propanol using $\mathrm{NaOH}$ as a base. Comparatively, a half sandwich ruthenium complex of the above-mentioned composition derived with various telluroethers of pyrrolidine, morpholine, and benzotriazole moieties ${ }^{62,172,173}$ also showed a similar efficiency rate with a short reaction time.

\subsection{Suzuki and Heck reaction}

Due to the air and moisture sensitivity of phosphorus-derived complexes, there is increasing interest in phosphine-free ligands ${ }^{\mathbf{1 7 4 - 1 7 7}}$ for the Suzuki-Miyaura reaction. With this prospect, palladium chalcogenolate ${ }^{178}$ complexes are considered as existing substituents for $\mathrm{C}-\mathrm{C}$ coupling reactions. Various coupling reactions are primarily catalyzed by palladium selenated and tellurated compounds. An early study performed by Prof. A. K. Singh et al. showed that palladium tellurolate complexes are as efficient as their selenium analogs. ${ }^{179}$ The conversion was found to be up to $85 \%$, particularly for activated 1-bromo-4-nitrobenzene (Scheme 27).

It is well documented that Pd-Se bonded compounds have promise for the Heck reaction. ${ }^{178}$ Within this continuation, a Schiff base-derived telluroether palladium complex showed good selectivity for the isolation of a trans-alkene product. The catalytic activity depended on the nature of the halide, while the electron-withdrawing groups on the aryl ring increased the reaction rate. For aryl bromides, a very small amount of complex (0.001 mmole) was sufficient to catalyze the Heck reaction (Scheme 27). ${ }^{179}$

\subsection{Material science}

Binary systems of Pt and Te (as a combination of metal and semiconductor) are important precursors for their application in the field of sensors and magnetic memories. ${ }^{180-182}$ In

$$
\begin{aligned}
& \mathrm{P}=\mathrm{COOH}, \mathrm{Ph}, \mathrm{COOMe} \\
& \mathrm{L} 1=\mathrm{p}-\mathrm{OMeC}_{6} \mathrm{H}_{4}\left(\mathrm{TeCH}_{2} \mathrm{CH}_{2} \mathrm{~N}=\mathrm{C}\left\{2-\mathrm{CH}_{3}\right) \mathrm{C}_{10} \mathrm{H}_{6} \mathrm{OH}\right) \\
& \mathrm{L} 2=\mathrm{p}-\mathrm{OMeC}_{6} \mathrm{H}_{4}\left(\mathrm{Te}_{2}-\mathrm{Ce}_{3}, 24 \mathrm{~h}, 100^{\circ} \mathrm{C}\right.
\end{aligned}
$$

Scheme 27 Representation of palladium-platinum tellurolate catalyzed Suzuki and Heck reactions. 
particular, the composites of $\mathrm{PtTe}_{2}$ are known to enhance the Seebeck coefficient of PbTe bulk particles. ${ }^{183}$ Similarly, multicomponent rod-shaped mixed composites FePt-PtTe $\mathrm{P}_{2}$ have exhibited high coercivity $(\mathrm{Hc}>500) .{ }^{184} \mathrm{Pt}_{3} \mathrm{Te}_{4}$ also has shown a catalytic ability in the transformation of nitrophenol to aminophenol. ${ }^{\mathbf{1 8 5}}$ Platinum group metal chalcogen materials are also prominently used for low resistance ohmic contacts. These thermodynamically stable contacts are very crucial for device durability. At the interface of Pt/CdTe diffusion couples, a non planner reaction layer of intermetallic $\mathrm{CdPt}$ and $\mathrm{Pt}-\mathrm{Te}$ is formed. ${ }^{186}$

Platinum group metal chalcogenides comprise various binary and ternary chalcogenide materials. Undoubtedly, the preparatory methods dealing with platinum group metal sulfide and selenide materials applying single source molecular precursor's methods are greater in number with respect to their tellurium precursors. ${ }^{187}$ The complex $\left[\mathrm{PdCl}\left\{\mathrm{Te}\left(3-\mathrm{MeC}_{5} \mathrm{H}_{3}\right.\right.\right.$ $\left.\mathrm{N})\}\left(\mathrm{PR}_{3}\right)\right](\mathrm{R}=$ propyl, $\mathrm{Ph})$ upon heating in a furnace at $340{ }^{\circ} \mathrm{C}$ under an argon atmosphere yielded a molecular precursor of the binary composition PdTe. ${ }^{\mathbf{1 3 0}}$ The latter compositions supported on carbon have relevance in various catalytic reactions used at an industrial scale. ${ }^{188}$ However, complexes like $\left[\mathrm{PdCl}_{2}(4-\right.$ $\left.\left.\mathrm{MeOC}_{6} \mathrm{H}_{4} \mathrm{TeCH}_{2} \mathrm{CH}_{2} \mathrm{~N}\left(\mathrm{CH}_{2} \mathrm{CH}_{2}\right)_{2} \mathrm{O}\right)\right]$ also result in the formation of Pd-Te nanoparticles of $5 \mathrm{~nm}$ diameter. ${ }^{189}$ A similar composition has also been documented by heating the hexanuclear complex at $>250{ }^{\circ} \mathrm{C} .{ }^{138}$ Thiolate- and selenolate-derived palladium complexes with the composition $\left[\mathrm{Pd}_{2}(\mu-\mathrm{ER})_{2}\left(\eta^{3}-\mathrm{C}_{4} \mathrm{H}_{7}\right)\right]$ $(\mathrm{E}=\mathrm{S}, \mathrm{Se})$ upon refluxing in xylene solution afforded $\mathrm{Pd}_{4} \mathrm{E}(\mathrm{E}=$ $\mathrm{S}, \mathrm{Se})$; however, the tellurolate analogs resulted in the formation of $\mathrm{Pd}_{3} \mathrm{Te}_{2}$ composites at room temperature. ${ }^{190}$ Recently, a composition of $\mathrm{Pd}_{7} \mathrm{Te}_{3}$ has been isolated upon refluxing the complex $\left[\mathrm{PdCl}_{2}\left(\mathrm{TeMes}_{2}\right)_{2}\right]$ in xylene solution. ${ }^{93}$

\subsection{Biological importance}

Upon evaluating the biological activity of tellurium-derived ruthenium complexes, it has been found that the complexes are quite potent as anticancer agents. Recently, a biological study of the complexes $\left[\left(\eta^{6}-\mathrm{p}-\mathrm{Me}_{6} \mathrm{H}_{4} \mathrm{Pr}^{i}\right)_{2} \mathrm{Ru}_{2}\left(\mu-\mathrm{TeC}_{6} \mathrm{H}_{5}\right)_{3}\right] \mathrm{PF}_{6}$ and $\left[\left(\eta^{5}-\mathrm{C}_{5} \mathrm{H}_{5}\right)_{2} \mathrm{Ru}_{2}\left(\mu-\mathrm{TeC}_{6} \mathrm{H}_{5}\right)_{3}\right] \mathrm{PF}_{6}$ (ref. 96) showed their good biological activity on normal and human cancer cell lines. The former complexes are even cyto-toxic in nature, which revealed their strong selectivity to cancer cells compared to normal ones. These promising outcomes of ruthenium complexes as anticancer agents deserves more exploration toward various other biological activities.

\section{Conclusions}

The versatile reactivity of organotellurolate ligands is quite evident from the ongoing discussions and reports in the literature. Their remarkable reactivity is derived due to presence of soft (tellurium) and hard donor atoms (N, O, S) in various ligands derived from organic moieties, like thinyl, pyridyl, furan, and pyrimidyl. In the meantime, one in particular cannot be declined: that the notable reactivity may also arise due to the comparable bond energies of Te-Te and Te-C bonds, which facilitates a competitive cleavage among them. Furthermore, among all the other chalcogens, the easy availability of lone pairs and high polarizability makes them great building block synthons for various heterometallic and high nuclearity metal complexes. It is hoped that this perspective will support further enthusiasm in this field and provide momentum for further research in this field to help establish their potential application in various fields.

\section{Conflicts of interest}

There are no conflicts to declare.

\section{Acknowledgements}

One of the authors (RSC) is grateful to DST for the financial support under the DST young scientist scheme YSS/2014/ 000797. We thank Dr V. K. Jain for his encouragement with this work and for his valuable suggestions for the preparation of this article.

\section{References}

1 (a) P. D. Akrivos, H. J. Katsikis and A. Koumoutsi, Coord. Chem. Rev., 1997, 167, 95; (b) P. D. Akrivos, Coord. Chem. Rev., 2001, 213, 181.

2 P. J. Blower and J. R. Dilworth, Coord. Chem. Rev., 1987, 76, 121.

3 J. R. Dilworth and N. Wheatley, Coord. Chem. Rev., 2000, 199, 89.

4 W. Levason, S. D. Orchid and G. Reid, Coord. Chem. Rev., 2002, 225, 159.

5 (a) S. Dey, V. K. Jain, A. Knoedler, A. Klein, W. Kaim and S. Zalis, Inorg. Chem., 2002, 41, 2864; (b) S. Dey, L. B. Kumbhare, V. K. Jain, T. Schurr, W. Kaim, A. Klein and F. Belaj, Eur. J. Inorg. Chem., 2004, 4510.

6 A. K. Singh and S. Sharma, Coord. Chem. Rev., 2000, 209, 49. 7 (a) G. Kedarnath and V. K. Jain, Coord. Chem. Rev., 2013, 257, 1409; (b) R. S. Chauhan, G. Kedarnath, A. Wadawale, A. Munoz-Castro, R. Arratia-Perez, V. K. Jain and W. Kaim, Inorg. Chem., 2010, 49, 4179.

8 (a) R. S. Chauhan, G. Kedarnath, A. Wadawale, A. L. Rheingold, A. Munoz-Castro, R. Arratia-Perez and V. K. Jain, Organometallics, 2012, 31, 1743; (b) R. S. Chauhan, G. Wadawale, A. M. Z. Slawin and V. K. Jain, Dalton Trans., 2013, 42, 259.

9 T. Wirth, Organoselenium Chemistry: Modern Developments in Organic Synthesis, in Topics in Current Chemistry, Springer-Verlag, Berlin, 2000, vol. 208.

10 S. Narayan, V. K. Jain and B. Varghese, J. Chem. Soc., Dalton Trans., 1998, 2359.

11 (a) D. Dakternieks, R. D. Giacomo, R. W. Gable and B. F. Hoskins, J. Am. Chem. Soc., 1988, 110, 6541; (b) D. Dakternieks, R. D. Giacomo, R. W. Gable and B. F. Hoskins, J. Organomet. Chem., 1989, 377, 43.

12 (a) A. K. Singh, V. Srivastava, J. K. Basumatary, T. P. Singh and A. K. Saxena, Phosphorus, Sulfur Silicon Relat. Elem., 
1994, 89, 31; (b) A. K. Singh, V. Srivastava, J. K. Basumatary, T. P. Singh and A. K. Saxena, Phosphorus, Sulfur Silicon Relat. Elem., 1993, 85, 175.

13 J. E. Drake, R. J. Drake, L. N. Khasrou and R. Ratnani, Inorg. Chem., 1996, 35, 2831.

14 V. P. Ananikov and I. P. Beletskaya, Org. Biomol. Chem., 2004, 2, 284.

15 (a) V. P. Ananikov, M. A. Kabeshov, I. P. Beletskaya, V. N. Khrustalev and M. Y. Antipin, Organometallics, 2005, 24, 1275; (b) I. P. Beletskaya and V. P. Ananikov, Eur. J. Org. Chem., 2007, 3431.

16 L. B. Han, N. Choi and M. Tanaka, J. Am. Chem. Soc., 1997, 119, 1795.

17 (a) N. Nakata, R. Uchiumi, T. Yoshino, T. Ikeda, H. Kamon and A. Ishii, Organometallics, 2009, 28, 1981; (b) A. Ishii, Y. Yamaguchi and N. Nakata, Dalton Trans., 2010, 39, 6181; (c) A. Ishii, N. Nakata, R. Uchiumi and K. Murakami, Angew. Chem., Int. Ed., 2008, 47, 2661.

18 Comprehensive Organometallic Chemistry - II, ed. R. J. Puddephatt, E. W. Abel, F. G. A. Stone and G. Wilkinson, Pergamon, Oxford, 1st edn, 1995, vol. 9, p. 1.

19 Catalytic Heterofunctionalization, ed. A. Togni and $\mathrm{H}$. Grützmacher, Wiley-VCH: Weinheim, 2001, p. 1.

20 M. E. Cucciolito, V. De Felice, G. Roviello and F. Ruffo, Eur. J. Inorg. Chem., 2011, 457.

21 R. Oilunkaniemi, R. S. Laitinen and M. J. Ahlgren, J. Organomet. Chem., 2001, 623, 168.

22 L. B. Han, N. Choi and M. Tanaka, J. Am. Chem. Soc., 1997, 119, 1795.

23 A. Khanna, B. L. Khandelwal, A. K. Saxena and T. P. Singh, Polyhedron, 1995, 14, 2705.

24 A. K. Singh, M. Kadarkaraisamy, M. Mishra, J. Sooriyakumar, J. E. Drake, M. B. Hursthouse, M. E. Light and J. P. Jasinski, Inorg. Chim. Acta, 2008, 361, 1426-1436.

25 G. Singh, A. K. Singh, P. Sharma, J. E. Drake, M. B. Hursthous and M. E. Light, J. Organomet. Chem., 2003, 688, 20-26.

26 P. R. Kumar, A. K. Singh, R. J. Butcher, P. S. Shrama and R. A. Toscano, Eur. J. Inorg. Chem., 2004, 1107-1114.

27 P. R. Kumar, S. Upreti and A. K. Singh, Inorg. Chim. Acta, 2008, 361, 1426-1436.

28 A. Kumar, M. Agarwal, A. K. Singh and R. J. Butcher, Inorg. Chim. Acta, 2009, 362, 3208; A. Kumar, M. Agarwal and A. K. Singh, J. Organomet. Chem., 2008, 693, 3533.

29 Y. Takaguchi, E. Horn and N. Furukawa, Organometallics, 1996, 15, 5112.

30 W. Levason, G. Reid and V. A. Tolhurst, J. Chem. Soc., Dalton Trans., 1998, 3411.

31 W. Levason, S. D. Orchard and G. Reid, Chem. Commun., 2001, 427.

32 S. C. Menon, H. B. Singh, R. P. Patel and S. K. Kulshreshtha, J. Chem. Soc., Dalton Trans., 1996, 1203.

33 E. G. Hope, T. Kemmit and W. Levason, Organometallics, 1988, 7, 78 .
34 J. Conolly, A. R. J. Genge, W. Levason, S. D. Orchard, S. J. A. Pope and G. Reid, J. Chem. Soc., Dalton Trans., 1999, 2343.

35 A. J. Barton, W. Levason, G. Reid and A. J. Ward, Organometallics, 2001, 20, 3644.

36 K. K. Bhasin, V. Arora, T. Klapotke and M. J. Crawford, Eur. J. Inorg. Chem., 2004, 4781.

37 K. K. Bhasin, N. Singh, R. Dhiman, G. Ram, Shivani, S. K. Mehta and R. J. Butcher, J. Organomet. Chem., 2006, 691, 628.

38 K. K. Bhasin, Rishu, S. Singh, H. Kumar and S. K. Mehta, J. Organomet. Chem., 2010, 695, 648.

39 A. Rodriguez, J. Romero, J. A. Garcia-Vazuez, M. L. Duran, A. Sousa Pedrares, A. Sousa and J. Zubieta, Inorg. Chim. Acta, 1999, 284, 133.

40 K. K. Bhasin, P. Venugopalan and J. Singh, Phosphorus, Sulfur Silicon Relat. Elem., 2002, 177, 2579.

41 L. Engman and M. P. Cava, Organometallics, 1982, 1, 470.

42 F. P. Colonna, G. Distfano, V. Galasso, K. J. Irgolic, G. C. Pappalardo and L. Pope, J. Chem. Soc., Perkin Trans. 2, 1981, 281.

43 L. A. Summers, J. Heterocycl. Chem., 1987, 24, 533.

44 L. Syper and J. Mlochowski, Tetrahedron, 1988, 44, 6119.

45 K. K. Bhasin, N. Singh, V. Trehan, P. K. Jain and J. Singh, Phosphorus, Sulfur Silicon Relat. Elem., 2003, 178, 753.

46 K. K. Bhasin, E. Arora, K. Kaur, S. K. Kang, M. Gobel, T. M. Klapoetke and S. K. Mehta, Tetrahedron, 2009, 65, 247.

47 K. K. Bhasin, E. Arora, S. K. Mehta and T. M. Klapoetke, J. Organomet. Chem., 2011, 696, 835.

48 R. S. Chauhan, R. K. Sahrma, G. Kedarnath, D. B. Cordes, A. M. Z. Slawin and V. K. Jain, J. Organomet. Chem., 2012, 717, 180.

49 K. K. Bhasin and J. Singh, J. Organomet. Chem., 2002, 658, 71.

50 K. K. Bhasin and V. Arora, Appl. Organomet. Chem., 2004, 18, 359.

51 K. K. Bhasin, V. Arora, S. K. Sharma and P. Venugopalan, Appl. Organomet. Chem., 2005, 19, 161.

52 R. Oilunkaniemi, R. S. Laitenen and M. Ahlgren, Inorg. Chem. Commun., 2000, 3, 8.

53 A. K. Singh, M. Misra and M. Kadarkaraisamy, Phosphorus, Sulfur Silicon Relat. Elem., 1998, 143, 101.

54 W. Levason, B. Patel, G. Reid and A. J. Ward, J. Organomet. Chem., 2001, 619, 218.

55 W. Levason, S. D. Orchard, G. Reid and V.-A. Tolhurst, J. Chem. Soc., Dalton Trans., 1999, 2071-2076.

56 W. Levason, S. D. Orchard and G. Reid, J. Chem. Soc., Dalton Trans., 2000, 4551.

57 W. Levason, S. D. Orchard and G. Reid, J. Chem. Soc., Chem. Commun., 1999, 1071.

58 W. Levason, S. D. Orchard and G. Reid, Inorg. Chem., 2000, 39, 3853.

59 A. K. Singh, M. Kadarkaraisamy, J. E. Drake and R. J. Butcher, Inorg. Chim. Acta, 2000, 304, 45.

60 A. K. Singh, J. Sooriyakumar, J. E. Drake, M. B. Hursthouse and M. E. Light, J. Organomet. Chem., 2000, 631, 244. 
61 S. Bali, A. K. Singh, J. E. Drake, M. B. Hursthouse and M. E. Light, J. Organomet. Chem., 2006, 3788.

62 S. Bali, A. K. Singh, P. Sharma, R. A. Toscaro, J. E. Drake, M. B. Hursthouse and M. E. Light, J. Organomet. Chem., 2004, 689, 2346.

63 D. Das, P. Singh and A. K. Singh, J. Organomet. Chem., 2010, 695, 955.

64 K. N. Sharma, H. Joshi, A. K. Sharma, O. Prakash and A. K. Singh, Chem. Commun., 2013, 49, 9344.

65 S. Kumar, G. K. Rao, A. Kumar, M. P. Singh and A. K. Singh, Dalton Trans., 2013, 42, 16939.

66 T. P. Lin and F. P. Gabbai, J. Am. Chem. Soc., 2012, 134, 12230.

67 P. Singh and A. K. Singh, Organometallics, 2010, 29, 6433.

68 A. J. Barton, W. Levason, G. Reid and V.-A. Tolhurst, Polyhedron, 2000, 19, 235.

69 M. Devery, R. S. Dickson, B. W. Skelton and A. H. White, Organometallics, 1999, 18, 5292.

70 L. Vigo, M. J. Poropudas, P. Salin, R. Oilunkaniemi and R. S. Laitinen, J. Organomet. Chem., 2009, 694, 2053.

71 P. Singh, D. Das, M. Singh and A. K. Singh, Inorg. Chem. Commun., 2010, 13, 988.

72 T. Kemmitt, W. Levason, R. D. Oldroyd and M. Webster, Polyhedron, 1992, 11, 2165.

73 A. K. Singh, M. Kadarkaraisamy, S. Husebye and K. W. Tornroos, J. Chem. Res., 2000, 64.

74 A. Z. Al-Rubaie, A. Al-Marzook and S. A. N. Al-Jadaan, Recl. Trav. Chim. Pays-Bas, 1996, 115, 427.

75 A. F. Chiffey, J. Evans, W. Levason and M. Webster, J. Chem. Soc., Dalton Trans., 1994, 2835.

76 B. L. Khandelwal, A. Khalid, A. K. Singh, T. P. Singh and S. Karthikeyan, J. Organomet. Chem., 1996, 507, 65.

77 J. E. Drake, J. Yang, A. Khalid, V. Srivastava and A. K. Singh, Inorg. Chim. Acta, 1997, 254, 57.

78 H. B. Singh, A. Regini, J. P. Jasinski, E. S. Paight and R. J. Butcher, J. Organomet. Chem., 1994, 466, 283.

79 A. K. Singh and V. Singh, Phosphorus, Sulfur Silicon Relat. Elem., 1993, 80, 95.

80 R. Batheja, S. Katiyar, V. Singh and A. K. Singh, Polyhedron, 1994, 13, 777.

81 R. Batheja and A. K. Singh, Polyhedron, 1997, 16, 2509.

82 R. Batheja and A. K. Singh, Polyhedron, 1997, 16, 4337.

83 A. Khanna and B. L. Khandelwal, Indian J. Chem., 1996, 35A, 236.

84 J. E. Drake, J. H. E. Bailey, A. K. Singh and V. Srivastava, Acta Crystallogr., 1993, (49), 684; A. K. Singh, V. Srivastava and B. L. Khandelwal, Polyhedron, 1990, 9, 851-857.

85 A. Khalid, B. L. Khandelwal, A. K. Singh, T. P. Singh and B. Padmanabhan, J. Coord. Chem., 1994, 31, 19.

86 A. Khaled and A. K. Singh, Polyhedron, 1996, 16, 33.

87 B. L. Khandelwal, A. Khalid and A. K. Singh, Indian J. Chem., 1996, 35A, 438.

88 A. Regini, R. Kaur, N. Sudha, S. C. Menon and H. B. Singh, Proc. - Indian Acad. Sci., Math. Sci., 1995, 107, 431.

89 R. Batheja, S. K. Dhingra and A. K. Singh, J. Organomet. Chem., 1995, 487, 173.
90 S. C. Menon, H. B. Singh, R. P. Patel and S. K. Kulshreshtha, J. Chem. Soc., Dalton Trans., 1996, 1203.

91 S. C. Menon, A. Panda, H. B. Singh and R. J. Butcher, J. Chem. Soc., Chem. Commun., 2000, 143.

92 A. Panda, S. S. Zade, H. B. Singh and R. J. Butcher, Eur. J. Inorg. Chem., 2006, 172.

93 S. Kolay, M. Kumar, A. Wadawale, D. Das and V. K. Jain, Dalton Trans., 2014, 43, 16056.

94 S. Kolay, M. Kumar, A. Wadawale, D. Das and V. K. Jain, J. Organomet. Chem., 2015, 794, 40.

95 S. Kolay, A. Wadawale, S. Nigam, M. Kumar, C. Majumder, D. Das and V. K. Jain, Inorg. Chem., 2015, 54, 11741.

96 T. Chakraborty, S. Sharma, H. B. Singh and R. J. Butcher, Organometallics, 2011, 30, 2525.

97 B. K. Das and M. G. Kanatzidis, Inorg. Chem., 1995, 34, 1011. 98 E. D. Schermer and W. H. Baddley, J. Organomet. Chem., 1971, 30, 67.

99 R. Nagarajaprakash, B. Ramakrishna, K. Mahesh, S. M. Mobin and B. Manimaran, Organometallics, 2013, 32, 7292.

100 N. Begum, M. I. Hyder, S. Islam, S. E. Kabir, K. Kundu and K. M. Abdul Malik, Indian J. Chem., 2005, 44A, 516.

101 K. A. Azam, M. Bhowmick, G. M. G. Hossain, S. E. Kabir, K. Kundu, K. M. A. Malik and S. Pervin, J. Chem. Crystallogr., 2001, 31, 63.

102 N. Begun, M. I. Hyder, M. R. Hassan, S. E. Kabir, D. W. Bennet, D. T. Haworth, T. A. Sidhiquee, D. Rokhsana, A. Sharmin and E. Rosenberg, Organometallics, 2008, 27, 1550.

103 S. Ghosh, G. Hogarth, S. E. Kabir, E. Nordlander, L. Salassa and D. A. Tocher, J. Organomet. Chem., 2011, 696, 1982.

104 Y. Nishibayashi, H. Imajima, G. Onodera, Y. Inade, M. Hidai and S. Uemura, Organometallics, 2004, 23, 5100.

105 A. A. Pasynskii, S. S. Shapovalov, I. V. Skabitsky, O. G. Tikhonova and T. A. Krishtop, Russ. J. Coord. Chem., 2015, 41, 234.

106 C. E. Rao, K. Yuvaraj and S. Ghosh, J. Organomet. Chem., 2015, 776, 123.

107 P. Mathur, I. J. Mavunkal and A. L. Rheingold, J. Chem. Soc., Chem. Commun., 1989, 382.

108 P. Mathur and I. J. Mavunkal, J. Organomet. Chem., 1988, 350, 251. 109 S. Chatterjee, S. K. Patel and S. M. Mobin, J. Organomet. Chem., 2011, 696, 1782.

110 P. Mathur, P. Payra, S. Ghosh, M. M. Hossain, C. V. V. Satyanarayana, F. O. Chicote and R. K. Chadha, J. Organomet. Chem., 2000, 606, 176.

111 P. Mathur, P. Sekar, C. V. V. Satyanarayana and M. F. Mahon, J. Chem. Soc., Dalton Trans., 1996, 2173.

112 P. Mathur, I. J. Mavunkal, V. Rugmini and M. F. Mahon, Inorg. Chem., 1990, 29, 4838.

113 P. Mathur, I. J. Mavunkal and V. Rugmini, Inorg. Chem., 1989, 28, 3616.

114 P. Mathur, B. H. S. Thimappa and A. L. Rheingold, Inorg. Chem., 1990, 29, 4658.

115 J. Zhang and W. K. Long, J. Chem. Soc., Dalton Trans., 2000, 1249-1253. 
116 S. E. Kabir, M. S. Saha, D. Tocher, G. M. G. Hossain and E. Rosenberg, J. Organomet. Chem., 2006, 691, 97; E. D. Schermer and W. H. Baddley, J. Organomet. Chem., 1971, 30, 67.

117 P. Srinivasan, M. E. Tai and W. K. Leong, J. Organomet. Chem., 2006, 691, 941-951.

118 S. Nagao, H. Seino, M. Hiddai and Y. Mizobe, Dalton Trans., 2005, 3166-3172.

119 M. P. Devery, R. S. Dickson, G. D. Fallon, G. A. Koutsantonis, B. W. Skelton and A. H. White, Z. Anorg. Allg. Chem., 2008, 634, 675.

120 M. P. Devery, R. S. Dickson, B. W. Skelton and A. H. White, Organometallics, 1999, 18, 5292.

121 A. Nordheider, K. S. A. Arachchige, A. M. Z. Slawin, J. D. Woollins and T. Chivers, Dalton Trans., 2015, 44, 8781.

122 R. D. Pergola, A. Ceriotti, A. F. de Biani, L. Garlaschelli, M. Manassero, R. Piacentini, M. Sansoni and P. Zanello, Organometallics, 1998, 17, 802.

123 Y.-K. Sau, X. Yi Yi, K.-W. Chan, C.-S. Lai, I. D. Williams and W.-H. Leung, J. Organomet. Chem., 2010, 695, 1399.

124 R. D. Adams, J. W. Long and J. L. Perrin, J. Am. Chem. Soc., 1998, 120, 1922.

125 J. M. Gonzales, D. G. Musaev and K. Morokuma, Organometallics, 2005, 24, 4908.

126 T. Nakagawa, H. Seino and Y. Mizobe, J. Organomet. Chem., 2010, 695, 137.

127 L. M. Venanzi, Chem. Ber., 1968, 4, 162.

128 E. Shustorovich and P. A. Dobosh, J. Am. Chem. Soc., 1979, 101, 4090.

129 D. M. Giolando, T. B. Rauchfuss and A. L. Rheingold, Inorg. Chem., 1987, 26, 1636.

130 S. Dey, V. K. Jain, J. Singh, V. Trehan, K. K. Bhasin and B. Varghese, Eur. J. Inorg. Chem., 2003, 744.

131 S. Dey, K. Vivekananda, A. P. Wadawale, V. K. Jain and N. Bhuvanesh, ChemistrySelect, 2017, 2, 5073.

132 L. Y. Chia and W. R. McWhinnie, J. Organomet. Chem., 1978, 148, 165.

133 (a) M. Risto, E. M. Jahr, M. S. Hannu-Kurre, R. Oilunkaniemi and R. S. Laitinen, J. Organomet. Chem., 2007, 692, 2193; (b) R. Oilunkaniemi, R. S. Laitinen and M. Ahlgren, J. Organomet. Chem., 2000, 595, 232.

134 N. V. Kirji, W. Tyrra, I. Pantenburg, D. Naumann, H. Scherer and Y. L. Yagupolskii, J. Organomet. Chem., 2006, 691, 2679.

135 S. Kato, O. Niyomura, Y. Kawahara and T. Kanda, J. Chem. Soc., Dalton Trans., 1999, 1677.

136 A. Wagner, L. Vigo, R. Oilukaniemi, R. S. Laitinen and W. Weigand, Dalton Trans., 2008, 3535; M. M. Karjalainen, T. Wiegand, J. M. Rautiainen, A. Wagner, H. Görls, W. Weigand, R. Oilunkaniemi and R. S. Laitinen, J. Organomet. Chem., 2017, 836, 17.

137 A. Singhal, V. K. Jain, B. Varghese and E. R. T. Tiekink, Inorg. Chim. Acta, 1999, 285, 190.

138 J. G. Brennam, T. Siegrist, S. M. Stuczynski and M. L. Steigerwald, J. Am. Chem. Soc., 1990, 112, 9233.

139 Y. Yamaguchi, N. Nakata and A. Ishii, Eur. J. Inorg. Chem., 2013, 5233.
140 R. S. Chauhan, G. Kedarnath, A. Wadawale, J. A. Golen, A. L. Rheingold and V. K. Jain, J. Organomet. Chem., 2013, 737, 40.

141 R. S. Chauhan, G. Kedarnath, J. A. Golen, A. L. Rheingold and V. K. Jain, Indian J. Chem., 2013, 52 A, 42.

142 C. Nishitani, T. Shizuka, K. Matsumoto, S. Okeya and H. Kioto, Inorg. Chem. Commun., 1998, 1, 325.

143 K. Matsumoto, K. Takahashi, M. Ikuzawa and H. Kimoto, Inorg. Chim. Acta, 1998, 281, 174.

144 A. L. Ma, J. B. Thoden and L. B. Dahl, J. Chem. Soc., Chem. Commun., 1992, 1516.

145 K. Matsumoto, M. Ikuzawa, M. Kamibuko and S. Ooi, Inorg. Chim. Acta, 1994, 129.

146 K. Matsumoto, C. Nishitani, M. Tadokoro and S. Okey, J. Chem. Soc., Dalton Trans., 1996, 3335.

147 M. R. Lewtas, C. P. Morley and M. Divaira, Polyhedron, 2000, 19, 751.

148 R. D. Adams, T. A. Wolfe, B. W. Eichhorn and R. C. Haushalter, Polyhedron, 1989, 8, 701.

149 H. Wolkers, K. Dehnicke, D. Fenske, J. Magull, C. Oliver and S. Weigerber, Z. Naturforsch., 1994, 64B, 4004.

150 M. G. Kanatzidis, Comments Inorg. Chem., 1990, 10, 161; Acta Crystallogr., Sect. C: Cryst. Struct. Commun., 1991, 47, 1193.

151 G. Thiele, G. You and S. Dehnen, Inorg. Chem., 2015, 54, 2491.

152 J. M. McConnachie, J. Bollinger and J. A. Ibers, Inorg. Chem., 1993, 32, 3923.

153 A. Gunther, A. Isaeva, A. I. Baranov and M. Ruck, Chem.Eur. J., 2011, 17, 6382.

154 A. Gunther, M. Heise, F. R. Wagner and M. Ruck, Angew. Chem., Int. Ed., 2011, 50, 9987.

155 A. Gunther, A. Isaeva and M. Ruck, Z. Anorg. Allg. Chem., 2013, 639, 254.

156 A. Gunther and M. Ruck, Z. Anorg. Allg. Chem., 2012, 638, 317.

157 T. Nakagawa, H. Seino, S. Nagao and Y. Mizobe, Angew. Chem., Int. Ed., 2006, 45, 7758.

158 A. A. Y. Pasynskii, V. Torubaev, A. Palova, I. V. Skanitsky, G. Denisov and V. Grinberg, J. Cluster Sci., 2015, 26, 247.

159 A. A. Pasynskii, Y. V. Torubaev, A. Pavlova, S. S. Shapovalov, I. V. Skabitskii and G. Denisov, Russ. J. Coord. Chem., 2014, 40, 611.

160 N. Petragnani and J. V. Comasseto, Synthesis, 1986, 1.

161 N. Petragnani and J. V. Comasseto, Synthesis, 1991, 793, 897.

162 J. V. Comasseto, L. W. Ling, N. Petragnani and H. A. Stefani, Synthesis, 1997, 373.

163 N. Petragnani, in Tellurium in Organic Synthesis-Best Synthetic Methods, ed. O. Meth-Cohn, Academic, 1994.

164 N. Petragnani and A. McKillop, Tellurium, in Comprehensive Organometallic Chemistry, Pergamon, NewYork, 1995, vol. 11.

165 H. Suzuki and T. Nakamura, J. Org. Chem., 1993, 58, 241.

166 N. Petragani and H. A. Stefani, Tetrahedron, 2005, 61, 1613.

167 G. Blay, L. Cardona, B. Garcia, L. Lahoz and J. R. Pedro, Tetrahedron, 1996, 52, 8611. 
168 A. S. Pepito and D. C. Dittmer, J. Org. Chem., 1997, 62, 7920. 169 W. Li, X. J. Zhou and Q. Ma, Synth. Commun., 1995, 25, 553. 170 C. C. Silveira, E. J. Lenardao and J. V. Comasseto, Synth. Commun., 1994, 24, 575.

171 V. Bargues, G. Blay, J. Fernandez and J. R. Pedro, Synlett, 1996, 655.

172 P. Singh, M. Singh and A. K. Singh, J. Organomet. Chem., 2009, 694, 3872.

173 P. Singh and A. K. Singh, Eur. J. Inorg. Chem., 2010, 4187.

174 I. G. Jung, S. U. Son, K. H. Park, K.-C. Chung, J. W. Lee and Y. K. Chung, Organometallics, 2003, 22, 4715.

175 E. Diez-Barra, J. Guerra, V. Hornillos, S. Merino and J. Tejeda, J. Organomet. Chem., 2003, 22, 4610; C. S. Consorti, M. L. Zanini, S. Leal, G. Ebeling and J. Dupont, Org. Lett., 2003, 5, 83.

176 J. Masllorens, M. Moreno-Manas, A. Pla-Quintana and A. Roglans, Org. Lett., 2003, 5, 1559.

177 S. B. Park and H. Alper, Org. Lett., 2003, 5, 3209; C. Mazet, L. H. Gade, Eur. J. Inorg. Chem., 2003, 1161.

178 Q. Yao, E. P. Kinney and C. Zheng, Org. Lett., 2004, 6, 2999.
179 A. Kumar, M. Agarwal and A. K. Singh, J. Organomet. Chem., 2008, 693, 3533.

180 D. H. Cobden, Nature, 2001, 409, 32.

181 Y. Cui, Q. Wei, H. Park and C. M. Lieber, Science, 2001, 293, 1289.

182 G. A. Prinz, Science, 1998, 282, 1660.

183 W. Zhou, J. Zhu, D. Li, H. H. Hng, F. Y. C. Boey, J. Ma, H. Zhang and Q. Yan, Adv. Mater., 2009, 21, 3196.

184 Q. Yan, M. S. Raghuveer, H. Li, B. Singh, T. Kim, M. Shima, A. Bose and G. Ramanath, Adv. Mater., 2007, 19, 3.

185 A. K. Samal and T. Pradeep, Langmuir, 2010, 26, 19136.

186 H. Cordes and R. Schmid-Fetzer, Semicond. Sci. Technol., 1994, 9, 2085.

187 S. Dey and V. K. Jain, Platinum Met. Rev., 2004, 48, 16.

188 (a) L. Y. Chiang, J. W. Swirczewski, R. Kastrup, C. S. Hsu and R. B. Upasani, J. Am. Chem. Soc., 1991, 113, 6574; (b) M. Misono and N. Nojiri, Appl. Catal., 1990, 64, 1.

189 P. Singh, D. Das, M. Singh and A. K. Singh, Inorg. Chem. Commun., 2010, 13, 988.

190 A. Singhal, V. K. Jain, R. Mishra and B. Varghese, J. Mater. Chem., 2000, 10, 1121. 